\title{
Open issues for protein function assignment in Haloferax volcanii and other halophilic archaea.
}

Friedhelm Pfeiffer ${ }^{1 \#}$ and Mike Dyall-Smith ${ }^{1,2}$

${ }^{1}$ Computational Biology Group, Max-Planck-Institute of Biochemistry, Martinsried, Germany

${ }^{2}$ Veterinary Biosciences, Faculty of Veterinary and Agricultural Sciences, University of Melbourne, Parkville, Australia

\section{Corresponding authors addresses:}

Dr. Friedhelm Pfeiffer

Computational Biology Group, Max-Planck-Institute of Biochemistry, Am Klopferspitz 18, 82152 Martinsried, Germany

e-mail: fpf@biochem.mpg.de 


\begin{abstract}
1 Abstract
3 Background: Annotation ambiguities and annotation errors are a general challenge in

4 genomics. While a reliable protein function assignment can be obtained by

5 experimental characterization, this is expensive and time-consuming, and the number

6 of such Gold Standard Proteins (GSP) with experimental support remains very low

7 compared to proteins annotated by sequence homology, usually through automated

8 pipelines. Even a GSP may give a misleading assignment when used as a reference:

9 the homolog may be close enough to support isofunctionality, but the substrate of the

10 GSP is absent from the species being annotated. In such cases the enzymes cannot be

11 isofunctional. Here, we examine a variety of such issues in halophilic archaea (class

12 Halobacteria), with a strong focus on the model haloarchaeon Haloferax volcanii.
\end{abstract}

13 Results: Annotated proteins of $H f x$. volcanii were identified for which public

14 databases tend to assign a function that is probably incorrect. In some cases, an

15 alternative, probably correct, function can be predicted or inferred from the available

16 evidence but this has not been adopted by public databases because experimental

17 validation is lacking. In other cases, a probably invalid specific function is predicted

18 by homology, and while there is evidence that this assigned function is unlikely, the

19 true function remains elusive. We list 50 of those cases, each with detailed

20 background information so that a conclusion about the most likely biological function

21 can be drawn. For reasons of brevity and comprehension, only key aspects are listed

22 in the main text, with detailed information being provided in a corresponding section

23 of the Supplementary Material.

24 Conclusions: Compiling, describing and summarizing these open annotation issues

25 and functional predictions will benefit the scientific community in the general effort

26 to improve the evaluation of protein function assignments and more thoroughly detail

27 them. By highlighting the gaps and likely annotation errors currently in the databases,

28 we hope this study will provide a framework for experimentalists to systematically

29 confirm (or disprove) our function predictions or to uncover yet unexpected functions.

31 Keywords: haloarchaea, genome annotation, Gold Standard Protein, Haloferax

32 volcanii, annotation error 


\section{INTRODUCTION}

Haloferax volcanii is a model organism for halophilic archaea (Hartman et al., 2010, Schulze et al., 2020, Leigh et al., 2011, Perez-Arnaiz et al., 2020, Soppa, 2011, Haque et al., 2020), for which an elaborate set of genetic tools has been developed (Allers et al., 2010, Allers and Mevarech, 2005, Kiljunen et al., 2014). Its genome has been sequenced and carefully annotated (Hartman et al., 2010, Pfeiffer et al., 2008a, Pfeiffer and Oesterhelt, 2015). A plethora of biological aspects have been successfully tackled in this species, with examples including DNA replication (Perez-Arnaiz et al., 2020); cell division and cell shape (Turkowyd et al., 2020, Walsh et al., 2019, de Silva et al., 2021, Duggin et al., 2015, Liao et al., 2021); metabolism (Brasen and Schonheit, 2001, Johnsen et al., 2009, Pickl et al., 2012, Sutter et al., 2016, Reinhardt et al., 2019, Kuprat et al., 2021, Kuprat et al., 2020, Sutter et al., 2020, Tästensen et al., 2020); protein secretion (Abdul-Halim et al., 2020, Abdul Halim et al., 2018, Abdul Halim et al., 2013, Storf et al., 2010); motility and biofilms (Schiller et al., 2020, Pohlschroder and Esquivel, 2015, Li et al., 2020, Collins et al., 2020, Quax et al., 2018, Nussbaum et al., 2020); mating (Shalev et al., 2017); signalling (Braun et al., 2019); virus defence (Maier et al., 2019); proteolysis (Reuter and Maupin-Furlow, 2004, Reuter et al., 2010, Prunetti et al., 2014, Cerletti et al., 2018, Cerletti et al., 2014, Costa et al., 2018); posttranslational modification (N-glycosylation; SAMPylation)(Cao et al., 2015, Kaminski and Eichler, 2014, Tripepi et al., 2012, Schulze et al., 2021, Shalev et al., 2018, Kandiba et al., 2016); gene regulation (Qi et al., 2016, Rawls et al., 2010, Hattori et al., 2016, Hwang et al., 2017, Johnsen et al., 2015, Tästensen et al., 2020, Reinhardt et al., 2019); microproteins (Zahn et al., 2021, Nagel et al., 2019, Kubatova et al., 2020) and small noncoding RNAs (sRNAs) (Straub et al., 2009, Heyer et al., 2012, Babski et al., 2014, Wyss et al., 2018).

Genome annotations are frequently compromised by annotation errors (Schnoes et al., 2009, Pfeiffer and Oesterhelt, 2015, Promponas et al., 2015, Danchin et al., 2018). Many of these errors are caused by invalid annotation transfer between presumed homologs, which, once introduced, are further spread by annotation robots. This problem can be partially overcome by using a Gold Standard Protein (GSP) based annotation strategy (Pfeiffer and Oesterhelt, 2015). Because the GSP has itself been subjected to experimental analysis, its annotation cannot be caused by an invalid 
annotation transfer process. The GSP strategy had already been applied to a detailed analysis of the metabolism of halophilic archaea (Falb et al., 2008). However, with decreasing level of sequence identity, the assumption of isofunctionality becomes increasingly insecure. Although this may be counterbalanced by additional evidence, e.g. gene clustering, experimental confirmation would be the best option for validation of the annotation.

There are additional and much more subtle genome annotation problems. In some cases, GSPs are true homologs and the annotated function in the database is correct. Nevertheless, the biological context in the query organism makes it unlikely that the homologs are isofunctional, e.g. when the substrate of the GSP is lacking in the query organism. Also, paralogs may have distinct but related functions, which cannot be assigned by sequence analysis but may be assigned based on phylogenetic considerations. Here, again, experimental confirmation is the preferred option for validation of the annotation. Lack of experimental confirmation may keep high-level databases like KEGG or the SwissProt section of UniProt from adopting assignments based on well-supported bioinformatic analyses, so that the database entries continue to provide information that is probably incorrect. We refer to annotation problems in these databases solely to underscore that the biological issues raised by us are far from trivial. There is no intention to question the exceedingly high quality of the SwissProt and KEGG databases (UniProt, 2021, Kanehisa et al., 2019) and their tremendous value for the scientific community. We have actively supported them by providing feedback and encourage others to do the same, e.g. with the recently implemented "Add a publication" functionality in UniProt entries, that allows users to connect a protein to a publication that describes its experimental characterization (https://community.uniprot.org/bbsub/bbsubinfo.html).

In this study, we describe a number of annotation issues for haloarchaea with a strong emphasis on $H f x$. volcanii. We denote such cases as 'open annotation issues' with the hope of attracting members of the Haloferax community and other groups working with halophilic archaea to apply experimental analyses to elucidate the true function(s) of these proteins. This will increase the number of Gold Standard Proteins 
99 which originate from $H f x$. volcanii or other haloarchaea, reduce genome annotation

100 ambiguities, and perhaps uncover novel metabolic processes.

101

102 MATERIALS AND METHODS

$103 \quad 2.1$ Curation of genome annotation and Gold Standard Protein identification

104 The Gold Standard Protein based curation of haloarchaeal genomes has been

105 described (Pfeiffer and Oesterhelt, 2015). Since then, a systematic comparison to

106 KEGG data was performed for a subset of the curated genomes (Pfeiffer et al., 2020).

107 The $H f x$. volcanii genome annotation is continuously scrutinized, especially when a

108 closely related genome is annotated (Tittes et al., 2021). The 16 haloarchaeal genomes

109 that are currently under survey are listed in Suppl. Table S11.

110

\section{$111 \quad 2.2$ Additional bioinformatics tools}

112 Key databases were UniProtKB/Swiss-Prot (UniProt, 2021), InterPro (Hunter et al., 113 2009), KEGG (Kanehisa et al., 2019), and OrthoDB (Kriventseva et al., 2019). The

114 SyntTax server was used for inspecting conservation of gene neighbourhood analysis 115 (Oberto, 2013). As general tools the BLAST suite of programs (Johnson et al., 2008, 116 Altschul et al., 1997) was used for genome comparisons. 


\section{RESULTS}

118 Open issues are organised below under the subsections (3.1), the respiratory chain and

119 oxidative decarboxylation; (3.2), amino acid metabolism; (3.3), heme and cobalamin

120 biosynthesis; (3.4), coenzyme F420; (3.5), tetrahydrofolate as opposed to

121 methanopterin; (3.6), NAD and riboflavin; (3.7), lipid metabolism; (3.8), genetic

122 information processing, and (3.9), stand-alone (miscellaneous) cases.

\subsection{The respiratory chain and oxidative decarboxylation}

In the respiratory chain, coenzymes that have been reduced during catabolism (e.g.

126 glycolysis) are reoxidized, with the energy being saved as an ion gradient. The

127 textbook example of a respiratory chain are the five mitochondrial complexes (Rich

128 and Marechal, 2010, Guo et al., 2018): complex I (NADH dehydrogenase), complex

129 II (succinate dehydrogenase), complex III (cytochrome bc $c_{1}$ complex), complex IV

130 (cytochrome-c oxidase as prototype for a terminal oxidase) and complex V (F-type

131 ATP synthase). In mitochondria, a significant part of the NADH which feeds into the

132 respiratory chain originates from oxidative decarboxylation: conversion of pyruvate to

133 acetyl-CoA by the pyruvate dehydrogenase complex and conversion of alpha-

134 ketoglutarate to succinyl-CoA by the homologous 2-oxoglutarate dehydrogenase

135 complex. While complex I and II transfer reducing elements to a lipid-embedded two-

136 electron carrier (ubiquinone), the $\mathrm{bc}_{1}$ complex transfers the electrons to the one-

137 electron carrier cytochrome-c, a heme (and thus iron) protein, which then transfers

138 electrons to the terminal oxidase.

140 Bacteria like Escherichia coli and Paracoccus have related complexes and enzymes:

141 NADH dehydrogenase (encoded by the nиo operon), succinate dehydrogenase

142 (encoded by $s d h A B C D$ ) and the related fumarate reductase (encoded by frdABCD)

143 (Crofts et al., 2013), several terminal oxidases (e.g. products of $c y o A B C D E, c y d A B C$ ),

144 and an F-type ATP synthase (encoded by atp genes). E. coli lacks a bc complex, $_{1}$

145 which, however, occurs in Paracoccus denitrificans (Kaila and Wikstrom, 2021). E.

146 coli contains the canonical complexes of oxidative decarboxylation (pyruvate

147 dehydrogenase complex, encoded by aceEF+lpdA, and 2-oxoglutarate dehydrogenase

148 complex, encoded by sucAB+lpdA). 
150 The respiratory chain of $H f x$. volcanii and other haloarchaea deviates considerably

151 from those of mitochondria and bacteria such as Paracoccus and E. coli (reviewed by

152 (Schafer et al., 1999)), and a number of questions remain unresolved. We focus on the

153 equivalents of complex I, III and IV, because these have unresolved issues. We also

154 cover some aspects relevant for NADH levels (oxidative decarboxylation enzymes

155 and type II NADH dehydrogenase). We do not cover complexes that have already

156 been studied in haloarchaea: complex II (succinate dehydrogenase) (Scharf et al.,

157 1997, Sreeramulu et al., 1998, Gradin et al., 1985) and complex V (ATP synthase)

158 (Steinert et al., 1997, Nanba and Mukohata, 1987).

159

160 (a) In haloarchaea, oxidative decarboxylation is not linked to reduction of NAD to

161 NADH but to reduction of a ferredoxin (encoded by $f d x$, e.g. OE_4217R, HVO_2995)

162 which has a redox potential similar to that of the NAD/NADH pair (Kerscher and

163 Oesterhelt, 1977). The enzymes for oxidative decarboxylation are pyruvate--

164 ferredoxin oxidoreductase (porAB, e.g. OE_2623R/2622R, HVO_1305/1304) and 2-

165 oxoglutarate--ferredoxin oxidoreductase (korAB, e.g. OE_1711R/1710R,

166 HVO_0888/0887), and these have been characterized from Halobacterium salinarum

167 (Plaga et al., 1992, Kerscher and Oesterhelt, 1981b, Kerscher and Oesterhelt, 1981a).

169 (b) In Hfx. volcanii, ferredoxin Fdx (HVO_2995) plays an essential role in nitrate

170 assimilation (Zafrilla et al., 2011). It may well be involved in additional metabolic

171 processes and it is yet unresolved how ferredoxin Fdx is reoxidised, but this might be

172 achieved by the Nuo complex.

173

174 (c) The nuo cluster of haloarchaea resembles that of E. coli, with genes and gene

175 order highly conserved, and just a few domain fissions and fusions. However,

176 haloarchaea lack NuoEFG (Falb et al., 2005), which is a subcomplex mediating

177 interaction with NADH (Leif et al., 1995, Braun et al., 1998). Thus, the haloarchaeal

178 nио complex is unlikely to function as NADH dehydrogenase, despite its annotation

179 as such in KEGG (as of April 2021). 
181 (d) Other catabolic enzymes generate NADH, which also must be reoxidized. Based

182 on inhibitor studies in Hbt. salinarum, NADH is not reoxidized by a type I but rather

183 by a type II NADH dehydrogenase (Sreeramulu et al., 1998). A gene has been

184 assigned for Natronomonas pharaonis (Falb et al., 2008). However, for reasons

185 detailed in Suppl.Text.S1, this assignment is highly questionable, so that this issue

186 calls for experimental analysis.

187

188 (e) About one-third of the haloarchaea, especially the Natrialbales, do not code for a

189 complex III equivalent (cytochrome $\mathrm{bc}_{1}$ complex encoded by petABC) according to

190 OrthoDB analysis. The $\mathrm{bc}_{1}$ complex is required to transfer electrons from the lipid-

191 embedded two-electron carrier (menaquinone in haloarchaea) to the one-electron

192 carrier associated with terminal oxidases (probably halocyanin). How electrons flow

193 in the absence of a complex III equivalent is currently unresolved.

The haloarchaeal petABC genes resemble those of the chloroplast b6-f complex rather than those of the mitochondrial bc 1 complex (see Suppl.Text S1 Section 1 for more

197 details).

(f) A bc cytochrome has been purified from Nmn. pharaonis, but with an atypical 1:1

200 ratio between the b-type and c-type heme (Scharf et al., 1997). The complex is

201 heterodimeric, with subunits of $18 \mathrm{kDa}$ and $14 \mathrm{kDa}$. The $18 \mathrm{kDa}$ subunit carries the

202 covalently attached heme group (Scharf et al., 1997). An attempt was made to identify

203 the genes coding for these subunits (Mattar, 1996) (for details see Suppl.Text S1

204 Section 1). Two approaches were used to obtain protein sequence data, one being N-

205 terminal protein sequencing of the two subunits extracted from a SDS-polyacrylamide

206 gel. In the other attempt, peptides from the purified complex were separated by

207 HPLC, and a peptide absorbing at $280 \mathrm{~nm}$ (protein) as well as $400 \mathrm{~nm}$ (heme) was

208 isolated. Absorption at $400 \mathrm{~nm}$ clearly indicates covalent attachment of the heme

209 group to the peptide. The sequences from the two approaches overlapped and resulted

210 in a contiguous sequence of 41 aa, with only the penultimate position remaining

211 undefined (Mattar, 1996). Based on this information, a PCR probe was generated 
212 (designated "cyt-C Sonde") that allowed the gene to be identified and sequenced,

213 including its genomic neighbourhood. It turned out that the genes coding for the four

214 subunits of succinate dehydrogenase $(s d h C D B A)$ had been isolated. The obtained

215 protein sequence corresponds to the $\mathrm{N}$-terminal region of $s d h D$ (with the initiator

216 methionine cleaved off) and only 2 sequence discrepancies in addition to the

217 unresolved penultimate residue.

219 In the $\mathrm{PhD}$ thesis (Mattar, 1996), this unambiguous result was rated to be a failure

220 (and the data were never formally published). The reason is that $\mathrm{SdhD}$ is free of

221 cysteine residues, while textbook knowledge states that a pair of cysteines is required

222 for covalent heme attachment (Kletzin et al., 2015). The lack of the required cysteine

223 pair was taken to indicate that the results were incorrect and that the identified genes

224 did not encode the cytochrome bc that the study had been seeking (Mattar, 1996). In

225 contrast, we speculate that the results were completely correct, despite being in

226 conflict with the cysteine pair paradigm. In our view, a paradigm shift is required. The

227 obtained results call for a yet unanticipated novel mode of covalent heme attachment,

228 exemplified by the $18 \mathrm{kDa}$ subunit of Natronomonas succinate dehydrogenase subunit

229 SdhD. It should be noted that the 41 aa protein sequence, which had been obtained,

230 turned out to contain three histidine residues upon translation of the gene, but none of

231 these had been detected upon Edman degradation.

233 In Halobacterium, a small c-type cytochrome was purified (cytochrome c552, 14.1

$234 \mathrm{kDa}$ ) (Sreeramulu, 2003). Heme staining after SDS-PAGE indicated a covalent heme

235 attachment, but no sequence or composition data were reported, so that it is not

236 possible to identify the protein based on the available information. We speculate that

237 the Halobacterium cytochrome c $552_{52}$ also represents $\mathrm{SdhD}$ (as detailed in Suppl.Text

238 S1 Section 1). In that case, the proposed novel type of covalent heme attachment

239 would not be restricted to Nmn. pharaonis but might be a general property of

240 haloarchaea. This would also solve the "Halobacterium paradox" (Kletzin et al.,

241 2015). 
243 (g) The haloarchaeal one-electron carrier is the copper protein halocyanin rather than

244 the iron-containing heme protein cytochrome-c. A halocyanin from Nmn. pharaonis

245 (NP_3954A) has been characterized, including its redox potential (Mattar et al., 1994,

246 Scharf and Engelhard, 1993, Hildebrandt et al., 1994). A gene fusion supports the

247 close connection of a halocyanin with a subunit of a terminal oxidase. For further

248 details see Suppl.Text S1 Section 1.

250 (h) Terminal oxidases are highly diverse in haloarchaea and we restrict our analysis to 251 three species (Nmn. pharaonis, Hfx. volcanii, and Hbt. salinarum) because in each of 252 these at least one terminal oxidase has been experimentally studied (Table 1). Details 253 are described in Suppl. Text S1 Section 1.

255 (i) NAD-dependent oxidative decarboxylation is a canonical reaction to convert 256 pyruvate into acetyl-CoA, and alpha-ketoglutarate into succinyl-CoA. In haloarchaea, 257 the conversion of pyruvate to acetyl-CoA and alpha-ketoglutarate to succinyl-CoA is 258 dependent on ferredoxin, not on NAD (see above). Nevertheless, most haloarchaeal 259 genomes also code for homologs of enzymes catalyzing NAD-dependent oxidative 260 decarboxylation, such as the E. coli pyruvate dehydrogenase complex. In most cases, 261 the substrates could not be identified, an exception being a paralog involved in 262 isoleucine catabolism (Sisignano et al., 2010). In several cases the enzymes were 263 found not to show catalytic activity with pyruvate or alpha-ketoglutarate (see 264 Suppl.Text S1 Section 1 for details). Also, a conditional lethal porAB mutant was 265 unable to grow on glucose or pyruvate, thus excluding that alternative enzymes for 266 conversion of pyruvate to acetyl-CoA exist in Hfx. volcanii (Kuprat et al., 2021). 267 Nonetheless, despite experimental results to the contrary, pyruvate is assigned as 268 substrate for some of the homologs of the pyruvate dehydrogenase complex in KEGG 269 (as of April 2021). 


\begin{tabular}{|c|c|c|c|c|c|c|c|c|c|}
\hline & & & & Gold & Standard Proteir & & & & \\
\hline $\begin{array}{c}\text { Sectio } \\
\mathbf{n}\end{array}$ & Code & Gene & isofunc & \%seq_id & Locus tag & UniProt & Reference & PMID & Comment \\
\hline $1 \mathrm{a}$ & $\begin{array}{l}\text { HVO_1305 } \\
\text { HVO_1304 }\end{array}$ & porAB & yes & $\begin{array}{l}67 \% \\
80 \%\end{array}$ & $\begin{array}{l}\text { OE2623R } \\
\text { OE2622R }\end{array}$ & $\begin{array}{l}\text { B0R4X6 } \\
\text { B0R4X5 }\end{array}$ & $\begin{array}{l}\text { (Plaga et al., 1992) } \\
\text { (Kerscher and Oesterhelt, 1981b) } \\
\text { (Kerscher and Oesterhelt, 1981a) }\end{array}$ & $\begin{array}{l}1555599 \\
6266826 \\
6266827\end{array}$ & \\
\hline $1 \mathrm{a}$ & $\begin{array}{l}\text { HVO_0888 } \\
\text { HVO_0887 }\end{array}$ & korAB & yes & $\begin{array}{l}77 \% \\
77 \%\end{array}$ & \begin{tabular}{|l} 
OE1711R \\
OE1710R
\end{tabular} & $\begin{array}{l}\text { B0R3G0 } \\
\text { B0R3F9 }\end{array}$ & $\begin{array}{l}\text { (Kerscher and Oesterhelt, 1981b) } \\
\text { (Kerscher and Oesterhelt, 1981a) }\end{array}$ & $\begin{array}{l}6266826 \\
6266827\end{array}$ & \\
\hline $1 \mathrm{a} / 1 \mathrm{~b}$ & HVO_2995 & $f d x$ & yes & $88 \%$ & OE4217R & B0R7I9 & $\begin{array}{l}\text { (Kerscher and Oesterhelt, 1976) } \\
\text { (Kerscher et al., 1976) } \\
\text { (Kerscher and Oesterhelt, 1977) }\end{array}$ & $\begin{array}{l}964365 \\
188650 \\
201489\end{array}$ & $\begin{array}{l}\text { role in oxidative } \\
\text { decarboxylation }\end{array}$ \\
\hline $1 \mathrm{a} / 1 \mathrm{~b}$ & $\begin{array}{l}\text { HVO_2995 } \\
\text { (cont.) }\end{array}$ & & & & self & D4GY89 & (Zafrilla et al., 2011) & 22103537 & $\begin{array}{l}\text { role in nitrate } \\
\text { assimilation }\end{array}$ \\
\hline $1 \mathrm{c}$ & $\begin{array}{l}\text { HVO_0979 } \\
\text { (complex) }\end{array}$ & пиов & possibly & $50 \%$ & tlr0705 & Q8DKZ4 & $\begin{array}{l}\text { (Zhang et al., 2005) } \\
\text { (Schuller et al., 2019) } \\
\text { (Pan et al., 2020) }\end{array}$ & $\begin{array}{l}15910282 \\
30573545 \\
32001694\end{array}$ & reoxidizes ferredoxin \\
\hline $1 \mathrm{c}$ & $\begin{array}{l}\begin{array}{l}\text { HVO_0979 } \\
\text { (cont.) }\end{array} \\
\end{array}$ & & no & $48 \%$ & b2287 & P0AFC7 & $\begin{array}{l}\text { (Leif et al., 1995) } \\
\text { (Braun et al., 1998) }\end{array}$ & $\begin{array}{l}7607227 \\
9485311 \\
\end{array}$ & $\begin{array}{l}\text { reoxidizes NADH in } \\
\text { E.coli }\end{array}$ \\
\hline $1 \mathrm{~d}$ & NP_3508A & $n d h 1$ & special & $\begin{array}{l}26 \%(\mathrm{~N}- \\
\text { term } 140 \\
\text { aa) }\end{array}$ & - & Q7ZAG8 & & & $\begin{array}{l}\text { function of Q7ZAG8 } \\
\text { was reassigned (from } \\
\text { ndh1 to sqr) after } \\
\text { annotation transfer }\end{array}$ \\
\hline $1 \mathrm{~d}$ & $\begin{array}{l}\text { NP_3508A } \\
\text { (cont.) }\end{array}$ & & possibly & $30 \%$ & \begin{tabular}{|l|} 
BpOF4_04810 \\
\end{tabular} & A7LKG4 & (Liu et al., 2008) & 18359284 & $\begin{array}{l}\text { type II NADH } \\
\text { dehydrogenase }\end{array}$ \\
\hline $1 \mathrm{e}$ & $\begin{array}{l}\text { HVO_2620 } \\
\text { HVO_0842 } \\
\text { HVO_0841 }\end{array}$ & petABD & yes & $39 \%$ & $\begin{array}{l}\text { SYNPCC7002_ } \\
\text { A0842 }\end{array}$ & P28056 & (Lee et al., 2001) & 11245788 & $\begin{array}{l}\text { HVO_0842(petB) } \\
\text { related to cytochrome } \\
\text { b6 }\end{array}$ \\
\hline 1f & HVO_2810 & $s d h D$ & yes & $66 \%$ & NP_4268A & Q3INS7 & $\begin{array}{l}\text { (Scharf et al., 1997) } \\
\text { (Mattar, 1996) }\end{array}$ & $\begin{array}{l}9109654 \\
\text { PhD_Matt } \\
\text { ar }\end{array}$ & \\
\hline $1 \mathrm{~g}$ & HVO_0943 & $c b a D$ & yes & $57 \%$ & NP_2966A & A0A1U7EWW4 & (Mattar and Engelhard, 1997) & 9428682 & \\
\hline & $\begin{array}{l}\text { HVO_0943 } \\
\text { (cont.) }\end{array}$ & & - & $63 \%$ & $\begin{array}{l}\text { OE_4073R } \\
\text { (C-term) }\end{array}$ & B0R7A9 & & - & $\begin{array}{l}\text { halocyanin/cbaD } \\
\text { fusion protein, } \\
\text { uncharacterized }\end{array}$ \\
\hline
\end{tabular}




\begin{tabular}{|c|c|c|c|c|c|c|c|c|c|}
\hline $1 \mathrm{~g}$ & HVO_2150 & $h c p G$ & - & $44 \%$ & $\begin{array}{l}\text { OE_4073R } \\
(\mathrm{N} \text {-term) }\end{array}$ & B0R7A9 & & - & $\begin{array}{l}\text { halocyanin/cbaD } \\
\text { fusion protein, } \\
\text { uncharacterized }\end{array}$ \\
\hline $1 \mathrm{~h}$ & $\begin{array}{l}\text { HVO_0945 } \\
\text { (complex) }\end{array}$ & $\operatorname{cbaA}$ & yes & $64 \%$ & NP_2966A & A0A1U7EWW4 & (Mattar and Engelhard, 1997) & 9428682 & \\
\hline $1 \mathrm{~h}$ & $\begin{array}{l}\text { HVO_0907 } \\
\text { (complex) }\end{array}$ & $\operatorname{coxAl}$ & & & self & & (Tanaka et al., 2002) & 11790755 & \\
\hline $1 \mathrm{~h}$ & $\begin{array}{l}\text { HVO_0907 } \\
\text { (cont.) }\end{array}$ & & yes & $70 \%$ & $\begin{array}{l}\text { VNG_0657G } \\
\text { (OE_1979R) }\end{array}$ & P33588 & $\begin{array}{l}\text { (Fujiwara et al., 1989) } \\
\text { (Denda et al., 1991) }\end{array}$ & $\begin{array}{l}2542239 \\
1659810\end{array}$ & \\
\hline $1 \mathrm{~h}$ & $\begin{array}{l}\text { HVO_1645 } \\
\text { (complex) }\end{array}$ & $\operatorname{coxAC2}$ & yes & $43 \%$ & APE_0793.1 & Q9YdX6 & (Ishikawa et al., 2002) & 12471503 & \\
\hline $1 \mathrm{~h}$ & $\begin{array}{l}\text { HVO_0462 } \\
\text { HVO_0461 }\end{array}$ & $c y d A B$ & yes & $\begin{array}{l}32 \% \\
24 \% \\
\end{array}$ & $\begin{array}{ll}- \\
-\end{array}$ & $\begin{array}{l}\text { Q09049 } \\
\text { Q05780 } \\
\end{array}$ & (Moshiri et al., 1991) & 1655703 & \\
\hline $1 \mathrm{~h}$ & $\begin{array}{l}\text { HVO_0462 } \\
\text { HVO_0461 } \\
\text { (cont.) }\end{array}$ & & yes & $\begin{array}{l}30 \% \\
27 \%\end{array}$ & $\begin{array}{l}\text { b0733 } \\
\text { b0734 }\end{array}$ & $\begin{array}{l}\text { P0ABJ9 } \\
\text { P0ABK2 }\end{array}$ & (Miller and Gennis, 1983) & 6307994 & \\
\hline $1 \mathrm{~h}$ & $\begin{array}{l}\mathrm{NP} \_4296 \mathrm{~A} \\
\mathrm{NP} \_4294 \mathrm{~A}\end{array}$ & $\begin{array}{l}\operatorname{coxA3} \\
\operatorname{coxB3}\end{array}$ & yes & $\begin{array}{l}28 \% \\
33 \% \\
\end{array}$ & $\begin{array}{l}\text { TTHA1135 } \\
\text { TTHA1134 }\end{array}$ & $\begin{array}{l}\text { Q5SJ79 } \\
\text { Q5SJ80 }\end{array}$ & $\begin{array}{l}\text { (Zimmermann et al., 1988) } \\
\text { (Keightley et al., 1995) }\end{array}$ & $\begin{array}{l}2842747 \\
7657607\end{array}$ & \\
\hline $1 \mathrm{i}$ & $\begin{array}{l}\text { HVO_2958 } \\
\text { HVO_2959 }\end{array}$ & oadhAB1 & & & self & $\begin{array}{l}\text { D4GY15 } \\
\text { D4GY17 }\end{array}$ & (Sisignano et al., 2010) & 19910413 & $\begin{array}{l}\text { Ile indirectly assigned } \\
\text { as substrate }\end{array}$ \\
\hline $1 \mathrm{i}$ & $\begin{array}{l}\text { HVO_2958 } \\
\text { HVO_2959 } \\
\text { (cont.) }\end{array}$ & & & & self & & $\begin{array}{l}\text { (Jolley et al., 2000) } \\
\text { (Al-Mailem et al., 2008) } \\
\text { (van Ooyen and Soppa, 2007) }\end{array}$ & $\begin{array}{l}10832633 \\
17571210 \\
17906130\end{array}$ & $\begin{array}{l}\text { no substrate was } \\
\text { identified;pyruvate and } \\
\text { alphaKG excluded }\end{array}$ \\
\hline $1 \mathrm{i}$ & $\begin{array}{l}\text { HVO_2595 } \\
\text { HVO_2596 }\end{array}$ & oadhAB2 & & & self & & $\begin{array}{l}\text { (Wanner and Soppa, 2002) } \\
\text { (van Ooyen and Soppa, 2007) } \\
\text { (Sisignano et al., 2010) }\end{array}$ & $\begin{array}{l}12003954 \\
17906130 \\
19910413\end{array}$ & $\begin{array}{l}\text { no substrate was } \\
\text { identified;pyruvate and } \\
\text { alphaKG excluded }\end{array}$ \\
\hline $1 \mathrm{i}$ & $\begin{array}{l}\text { HVO_0669 } \\
\text { HVO_0668 }\end{array}$ & oadhAB3 & & & self & & $\begin{array}{l}\text { (van Ooyen and Soppa, 2007) } \\
\text { (Sisignano et al., 2010) }\end{array}$ & $\begin{array}{l}17906130 \\
19910413\end{array}$ & $\begin{array}{l}\text { no substrate was } \\
\text { identified;pyruvate and } \\
\text { alphaKG excluded }\end{array}$ \\
\hline $1 \mathrm{i}$ & HVO_2209 & oadhA4 & & & self & & & & $\begin{array}{l}\text { not yet analyzed } \\
\text { experimentally }\end{array}$ \\
\hline $1 \mathrm{i}$ & $\begin{array}{l}\text { HVO_2958 } \\
\text { HVO_2959 } \\
\text { (cont.) }\end{array}$ & & yes/no & $\begin{array}{l}38 \% \\
52 \%\end{array}$ & $\begin{array}{l}\text { TA1438 } \\
\text { TA1437 }\end{array}$ & $\begin{array}{l}\text { Q9HIA3 } \\
\text { Q9HIA4 }\end{array}$ & (Heath et al., 2007) & 17894823 & $\begin{array}{l}\text { substrates are Ile, Leu, } \\
\text { Val }\end{array}$ \\
\hline
\end{tabular}




\begin{tabular}{|c|c|c|c|c|c|c|c|c|}
\hline $1 \mathrm{i}$ & $\begin{array}{l}\text { HVO_2595 } \\
\text { HVO_2596 } \\
\text { (cont.) }\end{array}$ & no & $\begin{array}{l}41 \% \\
41 \%\end{array}$ & - & $\begin{array}{l}\text { Q57102 } \\
\text { Q57041 }\end{array}$ & (Oppermann et al., 1991) & 1898934 & substrate is acetoin \\
\hline $1 \mathrm{i}$ & $\begin{array}{l}\text { HVO_2595 } \\
\text { HVO_2596 } \\
\text { (cont.) }\end{array}$ & unknown & $\begin{array}{l}40 \% \\
43 \%\end{array}$ & $\begin{array}{l}\text { BSU08060 } \\
\text { BSU08070 }\end{array}$ & $\begin{array}{l}\text { O31404 } \\
\text { O34591 }\end{array}$ & (Huang et al., 1999) & 10368162 & substrate is acetoin \\
\hline $1 \mathrm{i}$ & $\begin{array}{l}\text { HVO_0669 } \\
\text { HVO_0668 } \\
\text { (cont.) }\end{array}$ & unknown & $\begin{array}{l}54 \% \\
47 \%\end{array}$ & $\begin{array}{l}\text { BSU08060 } \\
\text { BSU08070 }\end{array}$ & $\begin{array}{l}\text { O31404 } \\
\text { O34591 }\end{array}$ & (Huang et al., 1999) & 10368162 & substrate is acetoin \\
\hline $1 \mathrm{i}$ & $\begin{array}{l}\text { HVO_0669 } \\
\text { HVO_0668 } \\
\text { (cont.) }\end{array}$ & unknown & $\begin{array}{l}49 \% \\
43 \%\end{array}$ & - & $\begin{array}{l}\text { Q57102 } \\
\text { Q57041 }\end{array}$ & (Oppermann et al., 1991) & 1898934 & substrate is acetoin \\
\hline $1 \mathrm{i}$ & $\begin{array}{l}\text { HVO_2209 } \\
\text { (cont.) }\end{array}$ & unknown & $38 \%$ & TA1438 & Q9HIA3 & (Heath et al., 2007) & 17894823 & $\begin{array}{l}\text { substrates are Ile, Leu, } \\
\text { Val }\end{array}$ \\
\hline
\end{tabular}

Table 1: Proteins with open annotation issues and their Gold Standard Protein homologs (Section 1). The column Section refers to the Table listing the protein and to the section in the Results and in Suppl. Text S1. As an example, 2c covers topic (ㄷ) from the decimal-numbered

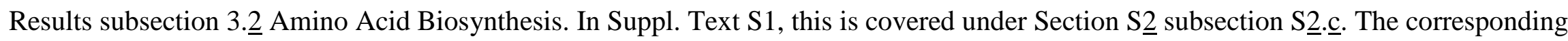
proteins are listed in Table 2. For a few proteins, two sections are indicated (e.g. 1a/1b). The column Code refers to a haloarchaeal protein by its locus tag, which is mainly from Haloferax volcanii (HVO), but also from Halobacterium salinarum (OE), Natronomonas pharaonis (NP) and Halohasta litchfieldiae (halTADL). When the reconstruction of a complete pathway is presented, the unassigned genes are indicated as a "pathway gap". In one case we indicate the absence of a haloarchaeal ortholog by a dash. In the case of a complex, we either list more than one code, or we list only one subunit together with the term (complex). All subunits of these complexes are listed groupwise in Table S10. A protein may be shown in more than one row. From the $2^{\text {nd }}$ row onwards, this is indicated by the term (cont.). The column Gene lists the assigned gene or a dash if no gene has been assigned. The assigned gene is only indicated in the first row of a protein. A set of four columns is used to relate a query protein to an experimentally characterized homolog, a GSP (Gold Standard Protein) (isofunc, \%seq_id, Locus tag, UniProt). The column 
isofunc indicates if the query protein and its Gold Standard Protein homolog are isofunctional. The meaning of the terms used in this column in

284 Tables 1-9 (yes, no, yes/no, probably, possibly, unclear, unknown, prediction, special, “-“) is described at the end of this legend. The column

$285 \%$ seq_id indicates the protein sequence identity between the query protein and the homologous GSP. The column Locus tag contains the locus

286 tag, if assigned. The column UniProt contains the UniProt accession of the GSP. GSPs have been experimentally characterized as described in a

287 publication. The column Reference links to the reference list of the manuscript. The column PMID lists the PubMed ID of the publication, if

288 available. Otherwise, this is indicated as "not in PubMed". Also, one PhD thesis is indicated (PhD_Matter). The column Comment provides

289 various types of additional information. The terms used in the column isofunc in Tables 1-9 have the following meaning: The term "yes"

290 indicates that we consider the two proteins as isofunctional and annotate the query protein accordingly. The term "no" is used when we conclude

291 that the proteins differ in function. Additional terms are used for more difficult cases. The term "yes/no" is used for GSPs which are

292 multifunctional, and we assign only one a subset of these functions to the query protein. The term "probably" is used when we consider

293 isofunctionality likely and annotated the query protein accordingly (with the term probable added to the protein name). The term "possibly" is

294 used when we see a good chance that the proteins are isofunctional, but consider it too speculative to annotate the protein accordingly. The term

295 "unclear" is used when we consider it likely that the same overall reaction is catalyzed, but when reaction details, e.g. the energy-providing

296 compound, is unresolved. The term "unknown" is used when it is not possible to predict the substrate of the query protein. The term "prediction"

297 is used if a function assignment is based on bioinformatic analyses but not yet on an experimentally characterized homologous protein. The term

298 "special" is used when multiple arguments have to be considered with full details provided in the corresponding section of Suppl. Text S1.

299 Finally, a dash (“-“) is used when isofunctionality does not apply, e.g. when a homologous Gold Standard Protein could not be identified. 


\subsection{Amino acid metabolism}

301 While most amino acid biosynthesis and degradation pathways can be reliably reconstructed, a few open issues remain, which are discussed below.

304 (a) The first and last steps of arginine biosynthesis deal with blocking and unblocking

305 of the alpha-amino group of the substrate (glutamate) and a product intermediate

306 (ornithine). As detailed in Suppl. Text S1 Section 2, it is highly likely that glutamate

307 is attached to the gamma-carboxyl group of a carrier protein, and ornithine is released

308 from that carrier protein. This is based on characterized proteins from Thermus

309 thermophilus (Horie et al., 2009), Thermococcus kodakarensis (Yoshida et al., 2016)

310 and Sulfolobus acidocaldarius (Ouchi et al., 2013). The assignment is strongly

311 supported by clustering of the arginine biosynthesis genes. Some of the homologs are

312 bifunctional, being involved in arginine biosynthesis but also in lysine biosynthesis

313 via the prokaryotic variant of the alpha-aminoadipate pathway. This ambiguity is not

314 assumed to occur in haloarchaea, which use the diaminopimelate pathway for Lys

315 biosynthesis (Hochuli et al., 1999) (see Suppl. Text S1 Section 2 for further

316 discussion of this issue).

318 Expanding the above, we provide full details underlying our reconstruction of

319 arginine and lysine biosynthesis in $H f x$, volcanii in Table 2. 


\begin{tabular}{|c|c|c|c|c|c|c|c|c|c|}
\hline & & & & Gold & Standard P & & & & \\
\hline $\begin{array}{l}\text { Sectio } \\
\text { n }\end{array}$ & Code & Gene & isofunc & \%seq_id & Locus tag & UniProt & Reference & PMID & Comment \\
\hline $2 \mathrm{a}$ & HVO_0047 & $\arg W$ & no & $54 \%$ & TT_C1544 & Q72HE5 & (Yoshida et al., 2015) & 25392000 & $\begin{array}{l}\text { for Arg, not for Lys } \\
\text { biosynthesis }\end{array}$ \\
\hline $2 \mathrm{a}$ & $\begin{array}{l}\text { HVO_0047 } \\
\text { (cont.) }\end{array}$ & & yes/no & $39 \%$ & Saci_0753 & Q4JAQ0 & & & $\begin{array}{l}\text { only for Arg, not for } \\
\text { Lys biosynthesis }\end{array}$ \\
\hline $2 \mathrm{a}$ & $\begin{array}{l}\text { HVO_0047 } \\
\text { (cont.) }\end{array}$ & & yes/no & $61 \%$ & TK0279 & Q5JFV9 & (Yoshida et al., 2016) & 27566549 & $\begin{array}{l}\text { only for Arg, not for } \\
\text { Lys biosynthesis }\end{array}$ \\
\hline $2 \mathrm{a}$ & HVO_0046 & $\arg X$ & no & $44 \%$ & TT_C1543 & Q72HE6 & (Horie et al., 2009) & 19620981 & $\begin{array}{l}\text { for Arg, not for Lys } \\
\text { biosynthesis }\end{array}$ \\
\hline $2 \mathrm{a}$ & $\begin{array}{l}\text { HVO_0046 } \\
\text { (cont.) }\end{array}$ & & yes & $30 \%$ & Saci_1621 & Q4J8E7 & & & $\begin{array}{l}\text { only for Arg, not for } \\
\text { Lys biosynthesis }\end{array}$ \\
\hline $2 \mathrm{a}$ & $\begin{array}{l}\text { HVO_0046 } \\
\text { (cont.) }\end{array}$ & & yes/no & $37 \%$ & TK0278 & Q5JFW0 & (Yoshida et al., 2016) & 27566549 & $\begin{array}{l}\text { only for Arg, not for } \\
\text { Lys biosynthesis }\end{array}$ \\
\hline $2 \mathrm{a}$ & HVO_0044 & $\arg B$ & no & $41 \%$ & TT_C1541 & O50147 & $\begin{array}{l}\text { (Horie et al., 2009) } \\
\text { (Yoshida et al., 2015) }\end{array}$ & $\begin{array}{l}19620981 \\
25392000 \\
\end{array}$ & $\begin{array}{l}\text { for Arg, not for Lys } \\
\text { biosynthesis }\end{array}$ \\
\hline $2 \mathrm{a}$ & $\begin{array}{l}\text { HVO_0044 } \\
\text { (cont.) }\end{array}$ & & yes/no & $33 \%$ & Saci_0751 & Q4JAQ2 & (Ouchi et al., 2013) & 23434852 & $\begin{array}{l}\text { only for Arg, not for } \\
\text { Lys biosynthesis }\end{array}$ \\
\hline $2 \mathrm{a}$ & $\begin{array}{l}\text { HVO_0044 } \\
\text { (cont.) }\end{array}$ & & yes/no & $32 \%$ & TK0276 & Q5JFW2 & (Yoshida et al., 2016) & 27566549 & $\begin{array}{l}\text { only for Arg, not for } \\
\text { Lys biosynthesis }\end{array}$ \\
\hline $2 \mathrm{a}$ & HVO_0045 & $\arg C$ & no & $48 \%$ & TT_C1542 & O50146 & $\begin{array}{l}\text { (Horie et al., 2009) } \\
\text { (Shimizu et al., 2016) }\end{array}$ & $\begin{array}{l}19620981 \\
26966182 \\
\end{array}$ & $\begin{array}{l}\text { for Arg, not for Lys } \\
\text { biosynthesis }\end{array}$ \\
\hline $2 a$ & $\begin{array}{l}\text { HVO_0045 } \\
\text { (cont.) }\end{array}$ & & yes/no & $42 \%$ & Saci_0750 & Q4JAQ3 & (Ouchi et al., 2013) & 23434852 & $\begin{array}{l}\text { only for Arg, not for } \\
\text { Lys biosynthesis }\end{array}$ \\
\hline $2 a$ & $\begin{array}{l}\text { HVO_0045 } \\
\text { (cont.) }\end{array}$ & & yes/no & $46 \%$ & TK0277 & Q5JFW1 & (Yoshida et al., 2016) & 27566549 & $\begin{array}{l}\text { only for Arg, not for } \\
\text { Lys biosynthesis }\end{array}$ \\
\hline $2 a$ & HVO_0043 & $\arg D$ & no & $45 \%$ & TT_C1393 & Q93R93 & (Miyazaki et al., 2001) & 11489859 & $\begin{array}{l}\text { for Arg, not for Lys } \\
\text { biosynthesis }\end{array}$ \\
\hline $2 a$ & $\begin{array}{l}\text { HVO_0043 } \\
\text { (cont.) }\end{array}$ & & yes/no & $40 \%$ & Saci_0755 & Q4JAP8 & (Ouchi et al., 2013) & 23434852 & $\begin{array}{l}\text { only for Arg, not for } \\
\text { Lys biosynthesis }\end{array}$ \\
\hline $2 a$ & $\begin{array}{l}\text { HVO_0043 } \\
\text { (cont.) }\end{array}$ & & yes/no & $42 \%$ & TK0275 & Q5JFW3 & (Yoshida et al., 2016) & 27566549 & $\begin{array}{l}\text { only for Arg, not for } \\
\text { Lys biosynthesis }\end{array}$ \\
\hline
\end{tabular}




\begin{tabular}{|c|c|c|c|c|c|c|c|c|c|}
\hline $2 a$ & HVO_0042 & $\arg E$ & no & $36 \%$ & TT_C1396 & Q8VUS5 & $\begin{array}{l}\text { (Horie et al., 2009) } \\
\text { (Fujita et al., 2017) }\end{array}$ & $\begin{array}{l}19620981 \\
28720495 \\
\end{array}$ & $\begin{array}{l}\text { for Arg, not for Lys } \\
\text { biosynthesis }\end{array}$ \\
\hline $2 \mathrm{a}$ & $\begin{array}{l}\text { HVO_0042 } \\
\text { (cont.) }\end{array}$ & & yes/no & $29 \%$ & Saci_0756 & Q4JAP7 & (Ouchi et al., 2013) & 23434852 & $\begin{array}{l}\text { only for Arg, not for } \\
\text { Lys biosynthesis }\end{array}$ \\
\hline $2 \mathrm{a}$ & $\begin{array}{l}\text { HVO_0042 } \\
\text { (cont.) }\end{array}$ & & yes/no & $37 \%$ & TK0274 & Q5JFW4 & (Yoshida et al., 2016) & 27566549 & $\begin{array}{l}\text { only for Arg, not for } \\
\text { Lys biosynthesis }\end{array}$ \\
\hline $2 \mathrm{a}$ & HVO_0041 & $\arg F$ & yes & $50 \%$ & P18186 & BSU11250 & (Issaly and Issaly, 1974) & 4216455 & \\
\hline $2 \mathrm{a}$ & $\begin{array}{l}\text { HVO_0041 } \\
\text { (cont.) }\end{array}$ & & yes & $47 \%$ & OE_5205R & B0R9X3 & (Ruepp et al., 1995) & 7868583 & \\
\hline $2 \mathrm{a}$ & HVO_0049 & $\arg G$ & yes & $35 \%$ & - & P00966 & (Shaheen et al., 1994) & 8792870 & human \\
\hline $2 \mathrm{a}$ & $\begin{array}{l}\text { HVO_0049 } \\
\text { (cont.) }\end{array}$ & & yes & $23 \%$ & b3172 & P0A6E4 & (Lemke et al., 1999) & 10666579 & E. coli \\
\hline $2 \mathrm{a}$ & HVO_0048 & $\operatorname{argH}$ & yes & $38 \%$ & MMP0013 & O74026 & (Cohen-Kupiec et al., 1999) & 10220900 & \\
\hline $2 a$ & HVO_0008 & lys $C$ & yes & $32 \%$ & BSU28470 & P08495 & (Kato et al., 2004) & 15033471 & \\
\hline $2 \mathrm{a}$ & HVO_2487 & asd & yes & $51 \%$ & MJ0205 & Q57658 & (Faehnle et al., 2005) & 16225889 & \\
\hline $2 \mathrm{a} / 9 \mathrm{e}$ & HVO_1101 & $\operatorname{dapA}$ & yes & $45 \%$ & PA1010 & Q9I4W3 & (Kaur et al., 2011) & 21396954 & \\
\hline $2 \mathrm{a}$ & HVO_1100 & $d a p B$ & yes & $33 \%$ & b0031 & P04036 & (Reddy et al., 1995) & 7893644 & \\
\hline $2 \mathrm{a}$ & HVO_1099 & dapD & yes & $32 \%$ & b0166 & P0A9D8 & (Simms et al., 1984) & 6365916 & \\
\hline $2 \mathrm{a}$ & HVO_1096 & dapE & yes & $29 \%$ & b2472 & P0AED7 & (Lin et al., 1988) & 3276674 & $\begin{array}{l}\text { function supported by } \\
\text { gene clustering }\end{array}$ \\
\hline $2 \mathrm{a}$ & HVO_1097 & dapF & yes & $35 \%$ & b3809 & P0A6K1 & (Wiseman and Nichols, 1984) & 6378903 & \\
\hline $2 \mathrm{a}$ & HVO_1098 & lys $A$ & yes & $38 \%$ & b2838 & P00861 & (White and Kelly, 1965) & 14343156 & \\
\hline $2 \mathrm{a}$ & HVO_A0634 & - & unknown & $25 \%$ & b2472 & P0AED7 & (Lin et al., 1988) & 3276674 & $\begin{array}{l}\text { function assigned to } \\
\text { HVO_1096 in dap } \\
\text { cluster }\end{array}$ \\
\hline $2 b$ & HVO_0790 & $f b a 2$ & special & $67 \%$ & OE_1472F & B0R334 & (Gulko et al., 2014) & 25216252 & $\begin{array}{l}\text { EC 2.2.1.10 activity of } \\
\text { OE_1472F not yet } \\
\text { confirmed in vitro }\end{array}$ \\
\hline $2 b$ & $\begin{array}{l}\text { HVO_0790 } \\
\text { (cont.) }\end{array}$ & & special & $45 \%$ & MJ0400 & Q57843 & (White, 2004) & 15182204 & substrate uncertain \\
\hline $2 b$ & HVO_0792 & aroB & yes & $69 \%$ & OE_1475F & B0R336 & (Gulko et al., 2014) & 25216252 & $\begin{array}{l}\text { OE_1475F only } \\
\text { partially characterized }\end{array}$ \\
\hline $2 b$ & $\begin{array}{l}\text { HVO_0792 } \\
\text { (cont.) }\end{array}$ & & yes & $44 \%$ & MJ1249 & Q58646 & (White, 2004) & 15182204 & \\
\hline $2 b$ & HVO_0602 & aroD1 & yes & $44 \%$ & OE_1477R & B0R338 & (Gulko et al., 2014) & 25216252 & \\
\hline
\end{tabular}




\begin{tabular}{|c|c|c|c|c|c|c|c|c|c|}
\hline $2 b$ & $\begin{array}{l}\text { HVO_0602 } \\
\text { (cont.) }\end{array}$ & & yes & $31 \%$ & MMP1394 & Q6LXF7 & (Porat et al., 2004) & 15262931 & \\
\hline $2 c$ & HVO_0009 & $\operatorname{tnaA}$ & yes & $41 \%$ & b3708 & P0A853 & $\begin{array}{l}\text { (Phillips and Gollnick, 1989) } \\
\text { (Newton et al., 1965) }\end{array}$ & $\begin{array}{l}2659590 \\
14284727\end{array}$ & \\
\hline $2 \mathrm{~d}$ & HVO_A0559 & hutH & yes & $42 \%$ & BSU39350 & P10944 & $\begin{array}{l}\text { (Oda et al., 1988) } \\
\text { (Hartwell and Magasanik, 1963) }\end{array}$ & $\begin{array}{l}2454913 \\
14066617\end{array}$ & \\
\hline $2 d$ & HVO_A0562 & hutU & yes & $62 \%$ & BSU39360 & P25503 & (Kaminskas et al., 1970) & 4990470 & \\
\hline $2 d$ & HVO_A0560 & hutI & yes & $42 \%$ & BSU39370 & P42084 & (Yu et al., 2006) & 16990261 & \\
\hline $2 \mathrm{~d}$ & HVO_A0561 & hutG & yes & $33 \%$ & BSU39380 & P42068 & (Kaminskas et al., 1970) & 4990470 & \\
\hline $2 \mathrm{e}$ & HVO_0431 & - & - & & & & & & no GSP available \\
\hline $2 \mathrm{e}$ & HVO_0644 & leuAl & yes/no & $47 \%$ & MJ1392 & Q58787 & (Howell et al., 1999) & 9864346 & $\begin{array}{l}\text { HVO_0644 monofunc } \\
\text { (CimA) or bifunc } \\
\text { (CimA+LeuA); } \\
\text { MJ1392 CimA }\end{array}$ \\
\hline $2 \mathrm{e}$ & $\begin{array}{l}\text { HVO_0644 } \\
\text { (cont.) }\end{array}$ & & unclear & $44 \%$ & MJ1195 & Q58595 & (Howell et al., 1998) & 9665716 & $\begin{array}{l}\text { HVO_0644 monofunc } \\
\text { (CimA) or bifunc } \\
\text { (CimA+LeuA); } \\
\text { MJ1195 LeuA }\end{array}$ \\
\hline $2 \mathrm{e} / 2 \mathrm{f}$ & HVO_1510 & leuA2 & yes & $47 \%$ & MJ1195 & Q58595 & (Howell et al., 1998) & 9665716 & $\begin{array}{l}\text { HVO_1510 LeuA; } \\
\text { MJ1195 LeuA }\end{array}$ \\
\hline $2 \mathrm{e} / 2 \mathrm{f}$ & $\begin{array}{l}\mathrm{HVO}_{1} 1510 \\
\text { (cont.) }\end{array}$ & & no & $41 \%$ & MJ1392 & Q58787 & (Howell et al., 1999) & 9864346 & $\begin{array}{l}\text { HVO_1510 LeuA } \\
\text { MJ1392 CimA }\end{array}$ \\
\hline $2 \mathrm{e}$ & HVO_A0489 & - & no & $31 \%$ & MJ1392 & Q58787 & (Howell et al., 1999) & 9864346 & $\begin{array}{l}\text { HVO_A0489 general } \\
\text { function only; } \\
\text { MJ1392 CimA }\end{array}$ \\
\hline $2 \mathrm{e}$ & $\begin{array}{l}\text { HVO_A0489 } \\
\text { (cont.) }\end{array}$ & & no & $30 \%$ & MJ1195 & Q58595 & (Howell et al., 1998) & 9665716 & $\begin{array}{l}\text { HVO_A0489 general } \\
\text { function only; } \\
\text { MJ1195 LeuA }\end{array}$ \\
\hline $2 \mathrm{e}$ & HVO_1153 & - & - & & & & & & $\begin{array}{l}\text { function unassigned; } \\
\text { no GSP }\end{array}$ \\
\hline
\end{tabular}


324 (b) Archaea use a different precursor for aromatic amino acid biosynthesis than the

325 classical pathway. This has been resolved for Methanocaldococcus jannaschii and for

326 Methanococcus maripaludis (White, 2004, Porat et al., 2006). However, the initial

327 steps may differ from those reported for Methanocaldococcus in that fructose-1,6-

328 disphosphate rather than 6-deoxy-5-ketofructose might be a substrate (Gulko et al.,

329 2014). Up to now, a clean deletion of the corresponding enzymes and confirmation

330 with in vitro assays has not yet been achieved (for details see Suppl. Text S1 Section

$3312)$.

333 (c) The gene for tryptophanase (tpa) is stringently regulated in Haloferax, which is the

334 basis for using its promoter in the toolbox for regulated gene expression (Large et al.,

335 2007). The shutdown of this gene avoids tryptophan degradation when supplies are

336 scarce. Tryptophanase cleaves tryptophan into indole, pyruvate and ammonia. The

337 fate of indole is, however, yet unresolved.

339 (d) A probable histidine utilization cluster exists, based on characterized homologs

340 from Bacillus subtilis, but has not yet been experimentally verified.

342 (e) Among 16 auxotrophic mutants observed in a $H f x$. volcanii transposon insertion

343 library (Kiljunen et al., 2014), some could grow only in the presence of one (or

344 several) supplied amino acids. In many cases, the affected genes were known to be

345 involved in the corresponding pathway, but the others may lead to novel function

346 assignments. One affected gene resulted in histidine auxotrophy and the product of

347 this gene (HVO_0431) is an interesting candidate. The InterPro domain assignment

348 (HAD family hydrolase) fits to the only remaining pathway gap in histidine

349 biosynthesis (histidinol-phosphatase). In this context it should be noted that the

350 enzyme which catalyzes the preceding reaction (encoded by hisC) is part of a highly

351 conserved three-gene operon involved in polar lipid biosynthesis (see below). For

352 details see Suppl. Text S1 Section 2. One affected gene resulted in isoleucine

353 auxotrophy. The product of this gene (HVO_0644) is currently annotated to catalyze

354 two reactions, one being an early step in isoleucine biosynthesis (EC 2.3.1.182), the 
355 other being the first step after leucine biosynthesis branches off from valine

356 biosynthesis (EC 2.3.3.13) (see below, f) (for details see Suppl. Text S1 Section 2).

358 (f) $H f x$. volcanii codes for two paralogs with an attributed function as 2-

359 isopropylmalate synthase (EC 2.3.3.13). This is the first reaction specific to leucine

360 biosynthesis, when the pathway branches off valine biosynthesis. One paralog,

361 HVO_0644, is annotated as bifunctional, also catalyzing a chemically similar reaction

362 which is an early step in isoleucine biosynthesis (EC 2.3.1.182). When the gene

363 encoding HVO_0644 is disrupted by transposon integration, cells cannot grow in the

364 absence of isoleucine. It is unclear if the protein is really bifunctional and is really

365 involved in leucine biosynthesis, catalyzing the reaction of EC 2.3.3.13. The other

366 paralog, HVO_1510, belongs to an ortholog set with major problems concerning start

367 codon assignment. The ortholog set from the 16 genomes listed in Suppl. Table S11

368 were analyzed. When only canonical start codons are considered (ATG, GTG, TTG),

369 then the orthologs from Haloferax mediterranei, Nmn. pharaonis, Natronomonas

370 moolapensis and Halohasta litchfieldiae either lack a long highly conserved N-

371 terminal region, or they are disrupted (pseudogenes), being devoid of a potential start

372 codon. The gene from $H f x$. volcanii has a start codon (GTG) which is consistent to

373 that of Haloferax gibbonsii strain LR2-5 (but a GTA in $H f x$. gibbonsii strain ARA6).

374 In this region, the gene from $H f x$. mediterranei is closely related but has in-frame stop

375 codons. HVO_1510 is considerably longer than the orthologs from Haloquadratum

376 walsbyi, Haloarcula hispanica, and Natrialba magadii. The first alternative start

377 codon for HVO_1510 codes for Met-93. This protein was proteomically identified in

378 three ArcPP datasets (Schulze et al., 2020), and peptides upstream of Met-93 were

379 identified. This gene might be translated from an atypical start codon, either an in-

380 frame CTG, or an out-of-frame ATG, which would require ribosomal slippage (for

381 details see Suppl. Text S1 Section 2). It is tempting to speculate that translation occurs

382 only when leucine is not available.

\subsection{Coenzymes I: cobalamin and heme}

385 The classical heme biosynthesis pathway branches off cobalamin biosynthesis at the 386 level of uroporphyrinogen III. The alternative heme biosynthesis pathway (Bali et al., 387 2011), which is used by haloarchaea, has an additional common step, the conversion 
388 of uroporphyrinogen III to precorrin-2. For heme biosynthesis, precorrin-2 is

389 converted to siroheme. This pathway has been reconstructed (Siddaramappa et al.,

390 2012), except for the iron insertion step. For de novo cobalamin biosynthesis,

391 haloarchaea use the cobalt-early pathway with a cobalt-dependent key reaction being

392 catalyzed by CbiG (Moore et al., 2013). Several aspects of heme and cobalamin

393 biosynthesis in haloarchaea are yet unresolved. This is illustrated in Figure 1.
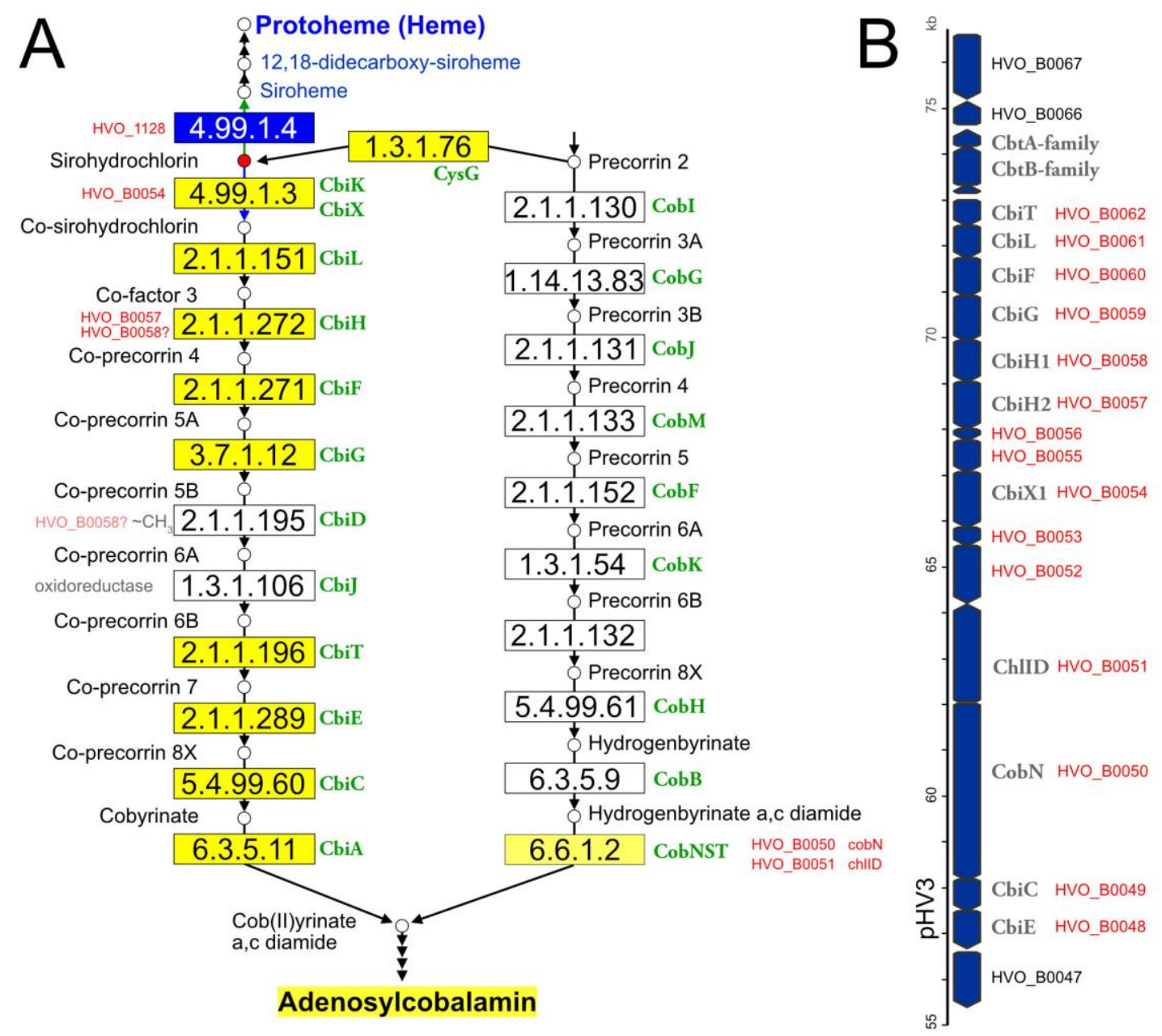

Figure 1. Illustration of the haloarchaeal cobalamin and heme biosynthesis pathways

398 illustration is based on the corresponding KEGG map 00860. Small circles represent pathway

399 intermediates and have their names assigned. Pathway intermediates upstream of Precorrin 2

400 are not displayed. The circle for sirohydrochlorin is highlighted in red as this is the

401 branchpoint for heme and cobalamin biosynthesis in haloarchaea. Enzymatic reactions are

402 shown by arrows, EC numbers being provided in rectangular boxes. Rectangles are colored

403 when the enzyme has been reconstructed for haloarchaea (blue: heme biosynthesis; dark 
404

405

406

407

408

409

410

411

412

413

414

415

416

yellow: de novo cobalamin biosynthesis; light yellow: late cobaltochelatase which may be a salvage reaction). Gene names in green are adopted from KEGG and represent those from bacterial model pathways. Consecutive arrowheads indicate reaction series which are not shown in detail for space reasons. For enzymatic reactions which are considered to be open issues, the $H f x$. volcanii locus tags are provided. For two pathway gaps (white boxes in the cobalt-early pathway), the type of reaction is indicated (oxidoreductase and $\sim \mathrm{CH} 3$, indicating a methylation reaction). The question mark after HVO_B0058 indicates that this protein, currently co-attributed to EC 2.1.1.272, is a candidate for the yet unassigned EC 2.1.1.195 reaction. We note that haloarchaea might use a deviating biosynthesis pathway, e.g. by swapping the methylation and oxidoreductase reactions (not illustrated). (B) The major cobalamin cluster, encoded on megaplasmid pHV3. Arrows are used to indicate the coding strand and are roughly drawn to scale. If assigned, the gene name is provided in addition to the $H f x$. volcanii locus tag. Locus tags in red indicate genes that are part of the cobalamin cluster.

(a) $H f x$. volcanii contains two annotated $c b i X$ genes. For reasons detailed in Suppl.Text S1 Section 3, we predict that one is a cobaltochelatase, involved in cobalamin biosynthesis, while the other is a ferrochelatase, responsible for conversion of precorrin- 2 to siroheme in the alternative heme biosynthesis pathway.

(b) De novo cobalamin biosynthesis has been extensively reconstructed upon curation of the genome annotation (Pfeiffer and Oesterhelt, 2015). All enzymes of the pathway and their associated GSPs are listed in Table 3. Only two pathway gaps remained, and because these are consecutive, it may be possible that the haloarchaeal pathway is non-canonical and proceeds via a novel biosynthetic intermediate. There are only four genes with yet unassigned function in the $H f x$. volcanii cobalamin gene cluster, and their synteny is well conserved in the majority of haloarchaeal genomes. Thus, these genes are obvious candidates for filling the pathway gaps (for details see Suppl.Text

\section{S1 Section 3).}

(c) The cobalamin biosynthesis and salvage reactions (those beyond ligand cobyrinate a,c diamide) involve "adenosylation of the corrin ring, attachment of the aminopropanol arm, and assembly of the nucleotide loop that bridges the lower ligand 
437 dimethylbenzimidazole and the corrin ring" (Rodionov et al., 2003). The enzymes of

438 these branches of cobalamin biosynthesis and their associated GSPs are listed in Table

439 3. Only two pathway gaps remain open. For one of these, a candidate was proposed

440 upon detailed bioinformatic analysis (Rodionov et al., 2003) (for further details see

441 Suppl.Text S1 Section 3).

443 (d) Haloarchaea may code for a late cobaltochelatase of the heterotrimeric type.

444 Distantly related GSPs are either cobalt or magnesium chelatases. A late

445 cobaltochelatase is not required for de novo cobalamin biosynthesis via the cobalt-

446 early pathway. We speculate that it may be involved in cobalamin salvage. The

447 chelatase has a mosaic subunit structure as also reported previously (Rodionov et al.,

448 2003) (see Suppl.Text S1 Section 3 for details).

450 (e) In the alternative heme biosynthesis pathway, siroheme is decarboxylated to

451 12,18-didecarboxysiroheme, which is attributed to the proteins encoded by $a h b A$ and

$452 a h b B$. These are homologous to each other and are organized as two two-domain

453 proteins. It is unclear if $\mathrm{AhbA}$ and $\mathrm{AhbB}$ function independently or if they form a 454 complex. 


\begin{tabular}{|c|c|c|c|c|c|c|c|c|c|}
\hline & & & & Gold & Standard Prot & & & & \\
\hline $\begin{array}{l}\text { Sectio } \\
\text { n }\end{array}$ & Code & Gene & isofunc & \%seq_id & Locus tag & UniProt & Reference & PMID & Comment \\
\hline $3 a$ & HVO_B0054 & cbiX1 & yes & $30 \%$ & - & O87690 & (Raux et al., 2003) & 12408752 & cobaltochelatase \\
\hline $3 a$ & $\begin{array}{l}\text { HVO_B0054 } \\
\text { (cont.) }\end{array}$ & & yes & $27 \%$ & MTH_1397 & $\mathrm{O} 27448$ & (Brindley et al., 2003) & 12686546 & cobaltochelatase \\
\hline $3 \mathrm{a}$ & HVO_1128 & cbiX2 & no & $29 \%$ & AF0721 & O29537 & (Yin et al., 2006) & 16835730 & cobaltochelatase \\
\hline $3 a$ & $\begin{array}{l}\mathrm{HVO}_{1} 1128 \\
\text { (cont.) }\end{array}$ & & no & $28 \%$ & MTH_1397 & $\mathrm{O} 27448$ & (Brindley et al., 2003) & 12686546 & cobaltochelatase \\
\hline $3 a$ & $\begin{array}{l}\text { HVO_1128 } \\
\text { (cont.) }\end{array}$ & & no & $29 \%$ & AF0721 & O29537 & (Yin et al., 2006) & 16835730 & cobaltochelatase \\
\hline $3 a$ & NP_0734A & cbiX3 & - & & & & & & $\begin{array}{l}\text { function unassigned; } \\
\text { no GSP; distantly } \\
\text { related to paralogs }\end{array}$ \\
\hline $3 a$ & HVO_2312 & $\operatorname{sirC}$ & yes/no & $31 \%$ & Mbar_A1461 & Q46CH4 & (Storbeck et al., 2010) & 21197080 & $\begin{array}{l}\text { precorrin-2 } \mathrm{DH} ; \text { no } \\
\text { analysis for } \mathrm{Fe}- \\
\text { chelatase }\end{array}$ \\
\hline $3 a$ & $\begin{array}{l}\text { HVO_2312 } \\
\text { (cont.) }\end{array}$ & & yes/no & $29 \%$ & STM3477 & P25924 & $\begin{array}{l}\text { (Stroupe et al., 2003) } \\
\text { (Pennington et al., 2020) }\end{array}$ & $\begin{array}{l}14595395 \\
32054833\end{array}$ & $\begin{array}{l}\text { matches to the N-term } \\
\text { domain which is } \\
\text { bifunctional as } \\
\text { precorrin-2 DH and Fe- } \\
\text { chelatase }\end{array}$ \\
\hline $3 a$ & $\begin{array}{l}\text { HVO_2312 } \\
\text { (cont.) }\end{array}$ & & yes/no & $29 \%$ & - & P61818 & $\begin{array}{l}\text { (Raux et al., 2003) } \\
\text { (Schubert et al., 2008) }\end{array}$ & $\begin{array}{l}12408752 \\
18588505 \\
\end{array}$ & $\begin{array}{l}\text { precorrin-2 DH; devoid } \\
\text { of Fe-chelatase activity }\end{array}$ \\
\hline $3 b$ & HVO_B0061 & cbiL & no & $32 \%$ & STM2024 & Q05593 & (Roessner et al., 1992) & 1451790 & $\begin{array}{l}\text { equivalent reaction on } \\
\text { cobalt-free substrate }\end{array}$ \\
\hline $3 b$ & HVO_B0057 & cbiH2 & yes & $45 \%$ & - & O87689 & (Moore et al., 2013) & 23922391 & $\begin{array}{l}\text { corresponds to N-term } \\
\text { of O87689 which has a } \\
\text { C-term extension }\end{array}$ \\
\hline $3 b$ & $\begin{array}{l}\text { HVO_B0057 } \\
\text { (cont.) }\end{array}$ & & no & $40 \%$ & STM2027 & Q05590 & $\begin{array}{l}\text { (Santander et al., 1997) } \\
\text { (Santander et al., 2006) }\end{array}$ & $\begin{array}{l}9331403 \\
16198574\end{array}$ & $\begin{array}{l}\text { equivalent reaction on } \\
\text { cobalt-free substrate }\end{array}$ \\
\hline $3 b$ & HVO_B0058 & cbiHl & special & $32 \%$ & - & O87689 & (Moore et al., 2013) & 23922391 & $\begin{array}{l}\text { corresponds to N-term } \\
\text { of O87689 which has a } \\
\text { C-term extension; }\end{array}$ \\
\hline
\end{tabular}




\begin{tabular}{|c|c|c|c|c|c|c|c|c|c|}
\hline & & & & & & & & & $\begin{array}{l}\text { more distant to } \mathrm{O} 87689 \\
\text { than } \mathrm{CbiH} 2\end{array}$ \\
\hline $3 b$ & $\begin{array}{l}\text { HVO_B0058 } \\
\text { (cont.) }\end{array}$ & & no & $30 \%$ & STM2027 & Q05590 & $\begin{array}{l}\text { (Santander et al., 1997) } \\
\text { (Santander et al., 2006) }\end{array}$ & $\begin{array}{l}9331403 \\
16198574\end{array}$ & $\begin{array}{l}\text { equivalent reaction on } \\
\text { cobalt-free substrate }\end{array}$ \\
\hline $3 b$ & HVO_B0060 & $c b i F$ & no & $40 \%$ & STM2029 & P0A2G9 & $\begin{array}{l}\text { (Roessner et al., 1992) } \\
\text { (Kajiwara et al., 2006) }\end{array}$ & $\begin{array}{l}1451790 \\
16866557 \\
\end{array}$ & $\begin{array}{l}\text { equivalent reaction on } \\
\text { cobalt-free substrate }\end{array}$ \\
\hline $3 b$ & $\begin{array}{l}\text { HVO_B0060 } \\
\text { (cont.) }\end{array}$ & & yes & $38 \%$ & - & O87686 & (Moore et al., 2013) & 23922391 & \\
\hline $3 b$ & HVO_B0059 & cbiG & yes & $24 \%$ & - & O87687 & (Moore et al., 2013) & 23922391 & \\
\hline $3 b$ & pathway gap & & & & & & & & EC 2.1.1.195 \\
\hline $3 b$ & pathway gap & & & & & & & & EC 1.3.1.106 \\
\hline $3 b$ & HVO_B0062 & $c b i T$ & yes & $36 \%$ & - & O87694 & (Moore et al., 2013) & 23922391 & $\begin{array}{l}\text { corresponds to the C- } \\
\text { term of bifunctional } \\
\text { O87694 }\end{array}$ \\
\hline $3 b$ & HVO_B0048 & cbiE & yes & $28 \%$ & - & O87694 & (Moore et al., 2013) & 23922391 & $\begin{array}{l}\text { corresponds to the N- } \\
\text { term of bifunctional } \\
\text { O87694 }\end{array}$ \\
\hline $3 b$ & HVO_B0049 & $c b i C$ & yes & $33 \%$ & - & O87692 & (Moore et al., 2013) & 23922391 & \\
\hline $3 b$ & HVO_A0487 & cbiA & no & $37 \%$ & STM2035 & P29946 & (Fresquet et al., 2004) & 15311923 & $\begin{array}{l}\text { equivalent reaction on } \\
\text { cobalt-free substrate }\end{array}$ \\
\hline $3 b$ & HVO_B0052 & - & - & & & & & & $\begin{array}{l}\text { function unassigned; } \\
\text { no GSP }\end{array}$ \\
\hline $3 b$ & HVO_B0053 & - & - & & & & & & $\begin{array}{l}\text { function unassigned; } \\
\text { no GSP }\end{array}$ \\
\hline $3 b$ & HVO_B0055 & - & - & & & & & & $\begin{array}{l}\text { function unassigned; } \\
\text { no GSP }\end{array}$ \\
\hline $3 b$ & HVO_B0056 & - & - & & & & & & $\begin{array}{l}\text { function unassigned; } \\
\text { no GSP }\end{array}$ \\
\hline $3 c$ & HVO_A0488 & $\operatorname{cobA}$ & yes & $31 \%$ & MM_3138 & Q8PSE1 & (Buan et al., 2006) & 16672609 & \\
\hline $3 c$ & $\begin{array}{l}\mathrm{HVO} \_\mathrm{A} 0488 \\
\text { (cont.) }\end{array}$ & & yes & $30 \%$ & STM1718 & P31570 & (Fonseca et al., 2002) & 12080060 & \\
\hline $3 c$ & HVO_2395 & $p d u O$ & yes & $37 \%$ & - & Q9XDN2 & (Johnson et al., 2001) & 11160088 & $\begin{array}{l}\text { PduO and CobA are } \\
\text { isofunctional; } \\
\text { In Q9XDN2, the PduO } \\
\text { domain (N-term) is }\end{array}$ \\
\hline
\end{tabular}




\begin{tabular}{|c|c|c|c|c|c|c|c|c|c|}
\hline & & & & & & & & & $\begin{array}{l}\text { fused to a DUF336 } \\
\text { domain }\end{array}$ \\
\hline $3 c$ & HVO_A0553 & cbiP & yes & $63 \%$ & $\begin{array}{l}\text { VNG_1576G } \\
\text { OE_3246F }\end{array}$ & $\begin{array}{l}\text { Q9HPL5 } \\
\text { B0R5X2 } \\
\end{array}$ & (Woodson et al., 2003b) & 14645280 & \\
\hline $3 \mathrm{c}$ & HVO_0587 & $c b i B$ & yes & $58 \%$ & $\begin{array}{l}\text { VNG_1578H } \\
\text { OE_3253F }\end{array}$ & $\begin{array}{l}\text { Q9HPL3 } \\
\text { B0R5X4 }\end{array}$ & (Woodson et al., 2003b) & 14645280 & \\
\hline $3 \mathrm{c}$ & HVO_0592 & cbiZ & yes & $57 \%$ & $\begin{array}{l}\text { VNG_1583C } \\
\text { OE_3261F }\end{array}$ & $\begin{array}{l}\text { Q9HPL3 } \\
\text { B0R5X8 }\end{array}$ & $\begin{array}{l}\text { (Woodson and Escalante- } \\
\text { Semerena, 2004) }\end{array}$ & 14990804 & \\
\hline $3 \mathrm{c}$ & HVO_0589 & $\operatorname{cobY}$ & yes & $47 \%$ & $\begin{array}{l}\text { VNG_1581C } \\
\text { OE_3257F }\end{array}$ & $\begin{array}{l}\text { Q9HPL1 } \\
\text { B0R5X6 }\end{array}$ & (Woodson et al., 2003a) & 12486068 & \\
\hline $3 \mathrm{c}$ & HVO_0588 & $\operatorname{cobS}$ & yes & $30 \%$ & STM2017 & Q05602 & $\begin{array}{l}\text { (Zayas and Escalante-Semerena, } \\
\text { 2007) }\end{array}$ & 17209023 & \\
\hline $3 c$ & - & & & & STM0643 & P39701 & (O'Toole et al., 1994) & 7929373 & $\begin{array}{l}\text { EC 3.1.3.73; CobC; no } \\
\text { homolog in } \\
\text { haloarchaea }\end{array}$ \\
\hline $3 c$ & HVO_0586 & - & prediction & - & - & - & (Rodionov et al., 2003) & 12869542 & 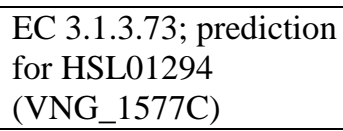 \\
\hline $3 \mathrm{c}$ & pathway gap & & & & & & & & EC 2.7.1.177 \\
\hline $3 \mathrm{c}$ & HVO_0591 & cobDl & yes & $31 \%$ & STM0644 & P97084 & (Brushaber et al., 1998) & 9446573 & \\
\hline $3 \mathrm{c}$ & HVO_0593 & cobD2 & yes & & & & & & $\begin{array}{l}\text { no GSP; } 51 \% \text { seq_id to } \\
\text { HVO_0591 (cobDl) }\end{array}$ \\
\hline $3 c$ & HVO_0590 & $\operatorname{cobT}$ & prediction & & & & (Rodionov et al., 2003) & 12869542 & $\begin{array}{l}\text { prediction for } \\
\text { VNG_1572C }\end{array}$ \\
\hline $3 \mathrm{c}$ & halTADL_3045 & $\operatorname{cobT}$ & yes & $39 \%$ & STM0644 & Q05603 & (Trzebiatowski et al., 1994) & 8206834 & \\
\hline $3 \mathrm{~d}$ & HVO_B0051 & $\operatorname{cobN}$ & yes & $34 \%$ & - & P29929 & (Debussche et al., 1992) & 1429466 & \\
\hline $3 \mathrm{~d}$ & $\begin{array}{l}\text { HVO_B0051 } \\
\text { (cont.) }\end{array}$ & & no & $29 \%$ & - & Q55284 & $\begin{array}{l}\text { (Jensen et al., 1996) } \\
\text { (Jensen et al., 1998) }\end{array}$ & $\begin{array}{l}8663186 \\
9716491 \\
\end{array}$ & Mg chelatase \\
\hline $3 \mathrm{~d}$ & HVO_B0050 & chlID & no & $46 \%$ & slr1030 & P51634 & $\begin{array}{l}\text { (Jensen et al., 1996) } \\
\text { (Jensen et al., 1998) }\end{array}$ & $\begin{array}{l}8663186 \\
9716491 \\
\end{array}$ & $\begin{array}{l}\text { match to N-term; } \\
\text { Mg chelatase }\end{array}$ \\
\hline $3 \mathrm{~d}$ & $\begin{array}{l}\text { HVO_B0050 } \\
\text { (cont.) }\end{array}$ & & no & $33 \%$ & slr1777 & P52772 & $\begin{array}{l}\text { (Jensen et al., 1996) } \\
\text { (Jensen et al., 1998) }\end{array}$ & $\begin{array}{l}8663186 \\
9716491\end{array}$ & $\begin{array}{l}\text { match to complete } \\
\text { sequence, incl distant } \\
\text { match to N-term; } \\
\text { Mg chelatase }\end{array}$ \\
\hline $3 e$ & HVO_1121 & $a h b C$ & yes & $47 \%$ & Mbar_A1793 & Q46BK8 & (Bali et al., 2011) & 21969545 & \\
\hline
\end{tabular}




\begin{tabular}{|c|c|c|c|c|c|c|c|c|c|}
\hline & & & & & & & (Kuhner et al., 2014) & 24669201 & \\
\hline $3 e$ & HVO_2144 & $a h b D$ & yes & $42 \%$ & Mbar_A1458 & Q46CH7 & (Kuhner et al., 2014) & 24669201 & \\
\hline $3 \mathrm{e}$ & HVO_2227 & $a h b A$ & yes & $35 \%$ & - & I6UH61 & (Bali et al., 2011) & 21969545 & \\
\hline $3 \mathrm{e}$ & HVO_2313 & $a h b B$ & yes & $32 \%$ & - & I6UH61 & (Bali et al., 2011) & 21969545 & \\
\hline
\end{tabular}

457 Table 3: Proteins with open annotation issues and their Gold Standard Protein homologs (Section 3). For a description of this table see the 458 legend to Table 1. 
459

460

461

462

463

464

465

466

467

468

469

470

471

472

473

474

475

476

477

478

479

480

481

482

483

484

485

487

488

486 (c) HVO_1937 might be a coenzyme F420-dependent 5,10-methylenetetrahydrofolate

\subsection{Coenzymes II: coenzyme F420}

Even though coenzyme F420 is predominantly associated with methanogenic archaea (Eirich et al., 1979, Jaenchen et al., 1984), it occurs also in bacteria and a small amount of this coenzyme has been detected in non-methanogenic archaea, including halophiles (Lin and White, 1986). The genes required for the biosynthesis of this coenzyme are encoded in haloarchaeal genomes, but the origin and attachment of the phospholactate moiety are not completely resolved (see below). To the best of our knowledge, only a single coenzyme F420 dependent enzymatic reaction has yet been reported for halophilic archaea (de Wit and Eker, 1987). Thus, the importance of this coenzyme in haloarchaeal biology is currently enigmatic and awaits experimental analysis.

(a) The pathway that creates the carbon backbone of this coenzyme has been reconstructed. We list the enzymes with their associated GSPs in Table 4. Coenzyme F420 contains a phospholactate moiety, which was reported to originate from 2phospho-lactate (Grochowski et al., 2008), but this compound is not well connected to the remainder of metabolism. As summarized in Suppl.Text S1 Section 4, there are various new insights regarding this pathway from recent studies in other prokaryotes (Bashiri et al., 2019, Braga et al., 2019). To the best of our knowledge, the haloarchaeal coenzyme F420 biosynthesis pathway has never been experimentally analyzed. .

(b) The prediction of coenzyme F420-specific oxidoreductases in Mycobacterium and actinobacteria has been reported (Selengut and Haft, 2010), leading to patterns and domains that are also found in haloarchaea. Several such enzymes are described in Suppl.Text S1 Section 4. reductase (see also below, C1 metabolism, and Suppl.Text S1 Section 4). 
bioRxiv preprint doi: https://doi.org/10.1101/2021.05.03.442417; this version posted May 16, 2021. The copyright holder for this preprint (which was not certified by peer review) is the author/funder, who has granted bioRxiv a license to display the preprint in perpetuity. It is made available under aCC-BY-NC-ND 4.0 International license.

489

(d) The precursor for coenzyme F420 may be used by a photo-lyase involved in DNA

490 repair. 


\begin{tabular}{|c|c|c|c|c|c|c|c|c|c|}
\hline & & & & Gold & Standard Prot & & & & \\
\hline $\begin{array}{l}\text { Sectio } \\
\text { n }\end{array}$ & Code & Gene & isofunc & \%seq_id & Locus tag & UniProt & Reference & PMID & Comment \\
\hline $4 a$ & HVO_2198 & $\operatorname{cofH}$ & yes & $35 \%$ & MJ1431 & Q58826 & $\begin{array}{l}\text { (Graham et al., 2003) } \\
\text { (Philmus et al., 2015) }\end{array}$ & $\begin{array}{l}14593448 \\
25781338 \\
\end{array}$ & \\
\hline $4 a$ & HVO_2201 & $\operatorname{cof} G$ & yes & $43 \%$ & MJ0446 & Q57888 & $\begin{array}{l}\text { (Graham et al., 2003) } \\
\text { (Decamps et al., 2012) } \\
\text { (Philmus et al., 2015) }\end{array}$ & $\begin{array}{l}14593448 \\
23072415 \\
25781338\end{array}$ & \\
\hline $4 \mathrm{a}$ & HVO_2202 & $\operatorname{cofC}$ & yes & $25 \%$ & MJ0887 & Q58297 & $\begin{array}{l}\text { (Grochowski et al., 2008) } \\
\text { (Bashiri et al., 2019) } \\
\text { (Braga et al., 2019) }\end{array}$ & $\begin{array}{l}18260642 \\
30952857 \\
31469543\end{array}$ & \\
\hline $4 \mathrm{a}$ & HVO_2479 & $\operatorname{cofD}$ & yes & $39 \%$ & MM_1874 & Q8PVT6 & $\begin{array}{l}\text { (Forouhar et al., 2008) } \\
\text { (Braga et al., 2019) }\end{array}$ & $\begin{array}{l}18252724 \\
31469543 \\
\end{array}$ & \\
\hline $4 a$ & $\begin{array}{l}\mathrm{HVO} \_2479 \\
\text { (cont.) }\end{array}$ & & yes & $32 \%$ & MJ1256 & Q58653 & (Graupner et al., 2002a) & 11888293 & \\
\hline $4 \mathrm{a}$ & HVO_1936 & $\operatorname{cof} E$ & yes & $47 \%$ & AF_2256 & O28028 & (Nocek et al., 2007) & 17669425 & \\
\hline $4 a$ & $\begin{array}{l}\text { HVO_1936 } \\
\text { (cont.) }\end{array}$ & & yes & $38 \%$ & MJ0768 & Q58178 & (Li et al., 2003) & 12911320 & \\
\hline $4 \mathrm{~b}$ & HVO_0433 & $n p d G$ & yes & $38 \%$ & AF_0892 & O29370 & (Kunow et al., 1993) & $\begin{array}{l}\text { not in } \\
\text { PubMed }\end{array}$ & \\
\hline $4 \mathrm{~b}$ & HVO_B0113 & - & no & $27 \%$ & Rv0132c & P96809 & $\begin{array}{l}\text { (Purwantini and Mukhopadhyay, } \\
\text { 2013) }\end{array}$ & 24349169 & $\begin{array}{l}\text { too distant to assume } \\
\text { isofunctionality }\end{array}$ \\
\hline $4 \mathrm{~b}$ & HVO_B0342 & - & unknown & $29 \%$ & - & O93734 & $\begin{array}{l}\text { (Klein et al., 1996) } \\
\text { (Aufhammer et al., 2004) }\end{array}$ & $\begin{array}{l}8706724 \\
15016352\end{array}$ & $\begin{array}{l}\text { too distant to assume } \\
\text { isofunctionality }\end{array}$ \\
\hline $4 \mathrm{~b}$ & NP_1902A & - & no & $28 \%$ & - & Q9UXP0 & $\begin{array}{l}\text { (Haase et al., 1992) } \\
\text { (Westenberg et al., 1999) }\end{array}$ & $\begin{array}{l}1735436 \\
9933933\end{array}$ & $\begin{array}{l}\text { too distant to assume } \\
\text { isofunctionality }\end{array}$ \\
\hline $4 \mathrm{~b}$ & NP_4006A & - & no & $27 \%$ & MJ0870 & Q58280 & $\begin{array}{l}\text { (Johnson and Mukhopadhyay, } \\
\text { 2005) }\end{array}$ & 16048999 & $\begin{array}{l}\text { too distant to assume } \\
\text { isofunctionality }\end{array}$ \\
\hline $4 \mathrm{c} / 5 \mathrm{c}$ & HVO_1937 & mer & no & $38 \%$ & MTH_1752 & $\mathrm{O} 27784$ & $\begin{array}{l}\text { (te Brömmelstroet et al., 1990) } \\
\text { (Vaupel and Thauer, 1995) } \\
\text { (Shima et al., 2000) }\end{array}$ & $\begin{array}{l}2298726 \\
7649177 \\
10891279\end{array}$ & \\
\hline $4 \mathrm{~d}$ & HVO_2911 & phr2 & yes & $62 \%$ & $\begin{array}{l}\text { VNG_1335G } \\
\text { OE_2907R }\end{array}$ & $\begin{array}{l}\text { Q9HQ46 } \\
\text { B0R5D6 }\end{array}$ & $\begin{array}{l}\text { (Takao et al., 1989) } \\
\text { (McCready and Marcello, 2003) }\end{array}$ & $\begin{array}{l}2681164 \\
12773185\end{array}$ & \\
\hline
\end{tabular}




\begin{tabular}{|c|c|c|c|c|c|c|c|c|c|}
\hline $4 d$ & HVO_2843 & phrl & no & $45 \%$ & s111629 & P77967 & (Brudler et al., 2003) & 12535521 & $\begin{array}{l}\text { sll1629 implicated in } \\
\text { transcription regulation }\end{array}$ \\
\hline $4 d$ & $\begin{array}{l}\text { HVO_2843 } \\
\text { (cont.) }\end{array}$ & & possibly & $45 \%$ & At5g24850 & Q84KJ5 & $\begin{array}{l}\text { (Kleine et al., 2003) } \\
\text { (Selby and Sancar, 2006) }\end{array}$ & $\begin{array}{l}12834405 \\
17062752\end{array}$ & $\begin{array}{l}\text { mediates photorepair } \\
\text { of ssDNA }\end{array}$ \\
\hline $4 d$ & HVO_1234 & phr3 & possibly & $40 \%$ & Atu4765 & A9CH39 & (Zhang et al., 2013) & 23589886 & \\
\hline
\end{tabular}

493 Table 4: Proteins with open annotation issues and their Gold Standard Protein homologs (Section 4). For a description of this table see the 494 legend to Table 1. 
3.5 Coenzymes III: coenzymes of $\mathrm{C} 1$ metabolism: tetrahydrofolate in haloarchaea, methanopterin in methanogens

497 Halophilic and methanogenic archaea use distinct coenzymes as one-carbon carrier

498 (C1 metabolism): tetrahydrofolate in haloarchaea and methanopterin in methanogens

499 (White, 1988, Maden, 2000). Several characterized methanogenic proteins that act on

500 or with methanopterin have comparably close homologs in haloarchaea (Table 5),

501 which results in misannotation of haloarchaeal proteins (e.g. in SwissProt) as being

502 involved in methanopterin biology. We assume that the haloarchaeal proteins function

503 with the haloarchaeal one-carbon carrier tetrahydrofolate and that this shift in

504 coenzyme specificity is possible due to the structural similarity between

505 methanopterin and tetrahydrofolate (a near-identical core structure consists of a pterin

506 heterocyclic ring linked via a methylene bridge to a phenyl ring; both also have a

507 polyglutamate tail). A detailed review on the many variants of the tetrahydrofolate

508 biosynthetic pathway is available (de Crecy-Lagard, 2014).

510 (a) Folate biosynthesis requires aminobenzoate. We had proposed candidates for a 511 pathway from chorismate to para-aminobenzoate (Falb et al., 2008, Pfeiffer et al., 512 2008b) (for details see Suppl.Text S1 Section 5). However, these predictions have not 513 been adopted by KEGG (accessed April 2021) and without experimental confirmation 514 this is unlikely to ever happen.

516 (b) GTP cyclohydrolase MptA (HVO_2348) catalyzes a reaction in the common part 517 of tetrahydrofolate and methanopterin biosynthesis. The enzymes specific for 518 methanopterin biosynthesis are absent from haloarchaea and thus the assignment of 519 HVO_2348 to the methanopterin biosynthesis pathway in UniProt is invalid (accessed 520 March 2021).

522 The next common pathway step (EC 3.1.4.56) has been resolved in M. jannaschii 523 (MJ0837) but still is a pathway gap in halophilic archaea. MJ0837 is very distantly 524 related to HVO_A0533, which thus is a promising candidate for experimental 525 analysis. 
527 HVO_2628 shows 30\% protein sequence identity to the enzyme catalyzing the first

528 committed step to methanopterin biosynthesis. As detailed in Suppl.Text S1 Section

5295 , we consider it likely that it does not catalyze that reaction.

531 (c) Two enzymes that alter the oxidation level of the coenzyme-attached one-carbon

532 compound probably function with tetrahydrofolate, even though their methanogenic

533 homologs function with methanopterin. In contrast to their assignments in KEGG and

534 UniProt (as of March 2021), their probable functions are thus

535 methenyltetrahydrofolate cyclohydrolase (HVO_2573) and 5,10-

536 methylenetetrahydrofolate reductase (HVO_1937) (see Suppl.Text S1 Section 5) 


\begin{tabular}{|c|c|c|c|c|c|c|c|c|c|}
\hline & & & & Gold & Standard Pro & & & & \\
\hline Sectio & Code & Gene & isofunc & \%seq_id & Locus tag & UniProt & Reference & PMID & Comment \\
\hline $5 \mathrm{a}$ & HVO_0709 & $p a b A$ & no & $47 \%$ & TTHA1843 & P05379 & (Sato et al., 1988) & 2844259 & Trp biosynthesis \\
\hline $5 \mathrm{a}$ & $\begin{array}{l}\mathrm{HVO}_{-} 0709 \\
\text { (cont.) }\end{array}$ & & yes/no & $39 \%$ & BSU00750 & P28819 & (Slock et al., 1990) & 2123867 & $\begin{array}{l}\text { TrpG works with TrpE } \\
\text { and with PabB }\end{array}$ \\
\hline $5 \mathrm{a}$ & HVO_0710 & $p a b B$ & no & $46 \%$ & TTHA1844 & P05378 & (Sato et al., 1988) & 2844259 & Trp biosynthesis \\
\hline $5 \mathrm{a}$ & $\begin{array}{l}\text { HVO_0710 } \\
\text { (cont.) }\end{array}$ & & yes & $44 \%$ & BSU00740 & P28820 & (Schadt et al., 2009) & 19275258 & $\begin{array}{l}\text { PabB; para- } \\
\text { aminobenzoate } \\
\text { biosynthesis }\end{array}$ \\
\hline $5 \mathrm{a}$ & HVO_0708 & $p a b C$ & no & $36 \%$ & AF_0933 & O29329 & (Isupov et al., 2019) & 30733943 & $\begin{array}{l}\text { branched-chain amino } \\
\text { acids }\end{array}$ \\
\hline $5 b$ & HVO_2348 & mptA & & & self & & (El Yacoubi et al., 2009) & 19478918 & $\begin{array}{l}\text { gene deletion } \\
\text { phenotypes }\end{array}$ \\
\hline $5 b$ & $\begin{array}{l}\text { HVO_2348 } \\
\text { (cont.) }\end{array}$ & & yes & $41 \%$ & MJ0775 & Q58185 & (Grochowski et al., 2007) & 17497938 & $\begin{array}{l}\text { common part of } \\
\text { methanopterin and } \\
\text { tetrahydrofolate } \\
\text { biosynthesis }\end{array}$ \\
\hline $5 b$ & HVO_A0533 & - & unknown & $27 \%$ & MJ0837 & Q58247 & (Mashhadi et al., 2009) & 19746965 & $\begin{array}{l}\text { if isofunctional would } \\
\text { resolve a pathway gap }\end{array}$ \\
\hline $5 b$ & HVO_2628 & - & no & $31 \%$ & AF_2089 & $\mathrm{O} 28190$ & (Scott and Rasche, 2002) & 12142414 & $\begin{array}{l}\text { first committed step to } \\
\text { methanopterin } \\
\text { biosynthesis }\end{array}$ \\
\hline $5 b$ & $\begin{array}{l}\text { HVO_2628 } \\
\text { (cont.) }\end{array}$ & & no & $26 \%$ & MJ1427 & Q58822 & (Dumitru and Ragsdale, 2004) & 15262968 & $\begin{array}{l}\text { first committed step to } \\
\text { methanopterin } \\
\text { biosynthesis }\end{array}$ \\
\hline $5 c$ & HVO_2573 & $m c h$ & no & $45 \%$ & MK0625 & P94954 & (Vaupel et al., 1998) & 9676239 & $\begin{array}{l}\text { acts on a one-carbon } \\
\text { attached to } \\
\text { methanopterin }\end{array}$ \\
\hline $4 c / 5 c$ & HVO_1937 & mer & no & $38 \%$ & MTH_1752 & $\mathrm{O} 27784$ & $\begin{array}{l}\text { (te Brömmelstroet et al., 1990) } \\
\text { (Vaupel and Thauer, 1995) } \\
\text { (Shima et al., 2000) }\end{array}$ & $\begin{array}{l}2298726 \\
7649177 \\
10891279\end{array}$ & $\begin{array}{l}\text { acts on a one-carbon } \\
\text { compound attached to } \\
\text { methanopterin }\end{array}$ \\
\hline
\end{tabular}




\section{$541 \quad 3.6$ Coenzymes IV: NAD and FAD (riboflavin)}

542 (a) The energy source for NAD kinase may be ATP or polyphosphate. This is

543 unresolved for the two paralogs of probable NAD kinase (HVO_2363, nadK1,

544 HVO_0837, nadK2). These show only $25 \%$ protein sequence identity to each other

545 (see Suppl. Text S1 Section 6). Polyphosphate was not found in exponentially

546 growing $H f x$. volcanii cells (Zerulla et al., 2014), so that ATP is the more likely

547 energy source.

549 (b) HVO_0782 is an enzyme involved in NAD biosynthesis, which is encoded in most

550 haloarchaeal and archaeal genomes. The adjacent gene, HVO_0781, is encoded in

551 nearly all haloarchaeal genomes according to OrthoDB, and with very strong syntenic

552 coupling revealed by SyntTax analysis. Thus, HVO_0781 is a candidate to also be

553 involved in NAD biosynthesis. Characterized homologs to HVO_0781 decompose S-

554 adenosyl-methionine into methionine and adenosine, a reaction that seems wasteful

555 and might not be expected to be highly conserved with respect to existence and gene

556 clustering (see Suppl. Text S1 Section 6).

557

558 (c) We describe the reconstruction of riboflavin biosynthesis based on a detailed

559 bioinformatic reconstruction (Rodionova et al., 2017). The enzymes and their

560 associated GSPs are listed in Table 6.Three pathway gaps remain, with candidate

561 genes predicted for two of these (Rodionova et al., 2017) (for details see Suppl. Text

562 S1 Section 6). 


\begin{tabular}{|c|c|c|c|c|c|c|c|c|c|}
\hline & & & & Gold & Standard $\mathbf{P}$ & & & & \\
\hline $\begin{array}{l}\text { Sectio } \\
\text { n }\end{array}$ & Code & Gene & isofunc & \%seq_id & Locus tag & UniProt & Reference & PMID & Comment \\
\hline $6 \mathrm{a}$ & HVO_2363 & nadKl & unclear & $37 \%$ & Rv1695 & P9WHV7 & (Kawai et al., 2000) & 11006082 & can use ATP and PP \\
\hline $6 a$ & $\begin{array}{l}\mathrm{HVO \_ 2363} \\
\text { (cont.) }\end{array}$ & & unclear & $31 \%$ & AF_2373 & O30297 & & & $\begin{array}{l}\text { ATP or PP usage } \\
\text { unresolved }\end{array}$ \\
\hline $6 \mathrm{a}$ & HVO_0837 & nadK2 & unclear & $28 \%$ & Rv1695 & P9WHV7 & & & can use ATP and PP \\
\hline $6 a$ & $\begin{array}{l}\mathrm{HVO \_} 0837 \\
\text { (cont.) }\end{array}$ & & unclear & partial & AF_2373 & O30297 & & & $\begin{array}{l}\text { ATP or PP usage } \\
\text { unresolved }\end{array}$ \\
\hline $6 \mathrm{~b}$ & HVO_0782 & nadM & yes & $53 \%$ & MJ0541 & Q57961 & $\begin{array}{l}\text { (Raffaelli et al., 1997) } \\
\text { (Raffaelli et al., 1999) }\end{array}$ & $\begin{array}{l}9401030 \\
10331644\end{array}$ & \\
\hline $6 \mathrm{~b}$ & HVO_0781 & - & unknown & $42 \%$ & Sare_1364 & A8M783 & (Eustaquio et al., 2008) & 18720493 & \\
\hline $6 \mathrm{~b}$ & $\begin{array}{l}\mathrm{HVO} \_0781 \\
\text { (cont.) }\end{array}$ & & unknown & $35 \%$ & PH0463 & O58212 & (Deng et al., 2008) & 18551689 & \\
\hline $6 \mathrm{~b}$ & HVO_0327 & $r i b B$ & yes & $43 \%$ & MJ0055 & Q60364 & (Fischer et al., 2002) & 12200440 & \\
\hline $6 \mathrm{~b}$ & HVO_0974 & ribH & yes & $45 \%$ & MJ0303 & Q57751 & (Haase et al., 2003) & 12603336 & \\
\hline $6 \mathrm{~b}$ & HVO_1284 & $\operatorname{arfA}$ & & self & & & (Phillips et al., 2012) & 21999246 & $\begin{array}{l}\text { gene deletion leads to } \\
\text { riboflavin auxotrophy }\end{array}$ \\
\hline $6 \mathrm{~b}$ & $\begin{array}{l}\text { HVO_1284 } \\
\text { (cont.) }\end{array}$ & & yes & $44 \%$ & MJ0145 & Q57609 & (Graham et al., 2002) & 12475257 & \\
\hline $6 \mathrm{~b}$ & HVO_1235 & - & prediction & & & & (Rodionova et al., 2017) & 28073944 & arfB candidate \\
\hline $6 \mathrm{~b}$ & HVO_1341 & $\operatorname{arfC}$ & yes & $36 \%$ & MJ0671 & Q58085 & $\begin{array}{l}\text { (Graupner et al., 2002b) } \\
\text { (Romisch-Margl et al., 2008) }\end{array}$ & $\begin{array}{l}11889103 \\
18671734\end{array}$ & \\
\hline $6 \mathrm{~b}$ & HVO_2483 & - & prediction & $34 \%$ & MJ0699 & Q58110 & (Rodionova et al., 2017) & 28073944 & $\begin{array}{l}\text { predicted also for } \\
\text { MJ0699 }\end{array}$ \\
\hline $6 \mathrm{~b}$ & pathway gap & & & & & & & & EC 3.1.3.104 \\
\hline $6 \mathrm{~b}$ & HVO_0326 & $r b k R$ & yes & $37 \%$ & TA1064 & Q9HJA6 & (Rodionova et al., 2017) & 28073944 & $\begin{array}{l}\text { bifunctional as gene } \\
\text { regulator and enzyme }\end{array}$ \\
\hline $6 \mathrm{~b}$ & $\begin{array}{l}\text { HVO_0326 } \\
\text { (cont.) }\end{array}$ & & yes/no & $32 \%$ & MJ0056 & Q60365 & (Ammelburg et al., 2007) & 18073108 & $\begin{array}{l}\text { enzyme only; lacks an } \\
\text { N-terminal HTH } \\
\text { domain }\end{array}$ \\
\hline $6 \mathrm{~b}$ & HVO_1015 & $r i b L$ & yes & $50 \%$ & MJ1179 & Q58579 & (Mashhadi et al., 2010) & 20822113 & \\
\hline
\end{tabular}


565 Table 6: Proteins with open annotation issues and their Gold Standard Protein homologs (Section 6). For a description of this table see the 566 legend to Table 1. 


\subsection{Biosynthesis of membrane lipids, bacterioruberin and menaquinone}

568 Archaeal membrane lipids contain ether-linked isoprenoid side chains (see (Caforio and Driessen, 2017) and references cited therein). The isoprenoid precursor isopentenyl diphosphate is synthesized in haloarchaea by a modified version of the mevalonate pathway (Vannice et al., 2014). Isoprenoid units are then linearly condensed to the $\mathrm{C} 20$ compound geranylgeranyl diphosphate. The haloarchaeal core lipid, archaeol, consists of 2,3-sn-glycerol with two C20 isoprenoid side chains attached by ether linkages. In some archaea, especially alkaliphiles, C25 isoprenoids are also found (see e.g. (De and Gambacorta, 1988, Dawson et al., 2012)). Also, a number of distinct headgroups are found in polar lipids (phospholipids) (reviewed in (Caforio and Driessen, 2017)). Even though polar lipids are used as important taxonomic markers (Oren et al., 1997) their biosynthetic pathways are not completely resolved.

Haloarchaea typically have a red color, which is due to carotenoids, mainly the C50

582 carotenoid bacterioruberin (Oren, 2002, Kushwaha et al., 1975, Yang et al., 2015).

583 For carotenoid biosynthesis, two molecules of geranylgeranyl diphosphate, a C20

584 compound, are linked head to head to generate phytoene, which is desaturated to

585 lycopene (Falb et al., 2008, Giani et al., 2020). The pathway from lycopene to the C50 586 compound bacterioruberin has been experimentally characterized (Dummer et al., 587 2011, Yang et al., 2015).

589 (a) We assigned HVO_2725 (idsA1, paralog of NP_3696A) and HVO_0303 (idsA2, 590 paralog of NP_0604A) for the linear isoprenoid condensation reactions resulting in a 591 C20 isoprenoid (EC 2.5.1.10, 2.5.29, short chain isoprenyl diphosphate synthase) (see 592 also Suppl.Text S1 Section 7). Some archaea, mainly haloalkaliphiles, also contain 593 C25 isoprenoid side chains. Geranylfarnesyl diphosphate synthase, the enzyme which 594 generates the C25 isoprenoids, has been purified and enzymatically characterized 595 from Nmn. pharaonis (Tachibana, 1994), but data that allow the assignment to a 596 specific gene have not been collected. Three paralogous genes from Nmn. pharaonis 597 are candidates for this function (NP_0604A, NP_3696A, and NP_4556A). Because 598 NP_0604A and NP_3696A have orthologs in Hfx. volcanii, a species devoid of C25 
599 lipids, we assign the synthesis of C25 isoprenoids (geranylfarnesyl diphosphate

600 synthase activity) to the third paralog, NP_4556A. UniProt assigns C25 biosynthesis

601 activity to NP_3696A for undescribed reasons (as of April 2021) and KEGG does not

602 make this assignment for any of the three paralogs (as of April 2021). Our

603 assignments are supported by analysis of key residues which determine the length of

604 the isoprenoid chain (Bale et al., 2019). These authors label the cluster containing

605 NP_3696A (WP011323557.1) as "C15/C20" and the cluster containing NP_4556A

606 (WP011323984.1) as “C20->C25->C30?”.

607

608 (b) Typical polar lipids in haloarchaea are phosphatidylglycerophosphate methyl ester

609 (PGP-Me) and phosphatidylglycerol (PG), but also phosphatidylglycerosulfate (PGS)

610 (Kates, 1993, Kates et al., 1993, Bale et al., 2019). Other polar lipids are

611 archaetidylserine and its decarboxylation product archaetidylethanolamine, both of

612 which are found in rather low quantities in Haloferax (Kellermann et al., 2016). A

613 third group of polar lipids has a headgroup derived from myo-inositol. The

614 biosynthetic pathway of the head groups is only partially resolved. One CDP-archaeol

615 1-archaetidyltransferase that belongs to a highly conserved three-gene operon may

616 attach either glycerol phosphate or myo-inositol phosphate. In Suppl. Text S1 Section

6177 we summarize arguments in favor of each of these candidates, but the true function

618 can only be decided by experimental analysis.

620 (c) Carotenoid biosynthesis involves the head-to-head condensation of the C20

621 isoprenoid geranylgeranyl diphosphate to phytoene, which is desaturated to lycopene

622 (Falb et al., 2008, Giani et al., 2020). The crtB gene product (e.g. HVO_2524)

623 catalyzes the head-to-head condensation. It is yet uncertain which gene product is

624 responsible for the desaturation of phytoene to lycopene. The further pathway from

625 lycopene to bacterioruberin has been experimentally characterized in Haloarcula

626 japonica (Yang et al., 2015). A three gene cluster (crtD-lyeJ-cruF) codes for the three

627 enzymes of this pathway. The synteny of this three gene cluster is strongly conserved

628 according to SyntTax analysis. Several genes which are certainly or possibly involved

629 in carotenoid biosynthesis are encoded in the vicinity of this cluster (for details see

630 Suppl. Text S1 Section 7). 
bioRxiv preprint doi: https://doi.org/10.1101/2021.05.03.442417; this version posted May $16,2021$. The copyright holder for this preprint

(which was not certified by peer review) is the author/funder, who has granted bioRxiv a license to display the preprint in perpetuity. It is made available under aCC-BY-NC-ND 4.0 International license.

632 (d) Halophilic archaea contain menaquinone as a lipid based two electron carrier of

633 the respiratory chain (Elling et al., 2016, Kellermann et al., 2016). We describe the

634 reconstruction of the menaquinone biosynthesis pathway (Table 7), with two pathway

635 gaps remaining open (see Suppl.Text S1 Section 7 for details). 


\begin{tabular}{|c|c|c|c|c|c|c|c|c|c|}
\hline & & & & Gold & Standard Prot & & & & \\
\hline $\begin{array}{l}\text { Sectio } \\
\text { n }\end{array}$ & Code & Gene & isofunc & \%seq_id & Locus tag & UniProt & Reference & PMID & Comment \\
\hline $7 \mathrm{a}$ & NP_0604A & idsA2 & yes & $32 \%$ & GACE_1337 & A0A0A7GEY4 & (Petrova et al., 2018) & 30062607 & $\begin{array}{l}\text { ortholog of } \mathrm{HVO} \_0303 \\
\text { (66\%); produces a C20 } \\
\text { isoprenoid (same } \\
\text { assignment for } \\
\text { NP_0604A) }\end{array}$ \\
\hline $7 \mathrm{a}$ & $\begin{array}{l}\text { NP_0604A } \\
\text { (cont.) }\end{array}$ & $i d s A 2$ & no & $30 \%$ & APE_1764 & $\begin{array}{l}\text { Q9YB31 } \\
\text { Q9UWR6 }\end{array}$ & (Tachibana et al., 2000) & 10632701 & $\begin{array}{l}\text { produces a C25 } \\
\text { isoprenoid (C20 } \\
\text { assigned to } \\
\text { NP_0604A) }\end{array}$ \\
\hline $7 a$ & NP_3996A & idsA3 & yes & $44 \%$ & GACE_1337 & A0A0A7GEY4 & (Petrova et al., 2018) & 30062607 & $\begin{array}{l}\text { ortholog of HVO_2725 } \\
\text { (67\%); produces a C20 } \\
\text { isoprenoid (same } \\
\text { assignment for } \\
\text { NP_3996A) }\end{array}$ \\
\hline $7 \mathrm{a}$ & $\begin{array}{l}\text { NP_3996A } \\
\text { (cont.) }\end{array}$ & idsA2 & no & $36 \%$ & APE_1764 & $\begin{array}{l}\text { Q9YB31 } \\
\text { Q9UWR6 }\end{array}$ & (Tachibana et al., 2000) & 10632701 & $\begin{array}{l}\text { produces a C25 } \\
\text { isoprenoid (C20 } \\
\text { assigned to } \\
\text { NP_3996A) }\end{array}$ \\
\hline $7 \mathrm{a}$ & NP_4556A & idsAl & no & $34 \%$ & GACE_1337 & A0A0A7GEY4 & (Petrova et al., 2018) & 30062607 & $\begin{array}{l}\text { no ortholog in } H f x . \\
\text { volcanii; produces a } \\
\text { C20 isoprenoid (C25 } \\
\text { assigned to } \\
\text { NP_4556A) }\end{array}$ \\
\hline $7 \mathrm{a}$ & $\begin{array}{l}\text { NP_4556A } \\
\text { (cont.) }\end{array}$ & idsAl & yes & $29 \%$ & APE_1764 & $\begin{array}{l}\text { Q9YB31 } \\
\text { Q9UWR6 }\end{array}$ & (Tachibana et al., 2000) & 10632701 & $\begin{array}{l}\text { produces a C25 } \\
\text { isoprenoid (same } \\
\text { assignment for } \\
\text { NP_4556A) } \\
\end{array}$ \\
\hline $7 \mathrm{~b}$ & HVO_0332 & $\operatorname{carS}$ & yes & $45 \%$ & AF_1740 & $\mathrm{O} 28537$ & (Jain et al., 2014) & 25219966 & \\
\hline $7 \mathrm{~b}$ & HVO_1143 & assA & yes & $32 \%$ & MTH_1027 & O27106 & (Morii and Koga, 2003) & 12562787 & gene synonym: $p g s A 3$ \\
\hline $7 \mathrm{~b}$ & HVO_1297 & aisA & yes & $25 \%$ & MTH_1691 & O27726 & (Morii et al., 2009) & 19740749 & gene synonym: $p g s A 2$ \\
\hline
\end{tabular}




\begin{tabular}{|c|c|c|c|c|c|c|c|c|c|}
\hline $7 \mathrm{~b}$ & HVO_1136 & pgsAl & - & & & & & & $\begin{array}{l}\text { only distant partial } \\
\text { matches to GSPs }\end{array}$ \\
\hline $7 \mathrm{~b}$ & HVO_1971 & pgsA4 & unclear & $26 \%$ & MTH_1027 & O27106 & (Morii and Koga, 2003) & 12562787 & $\begin{array}{l}\text { MTH_1027 is less } \\
\text { distant to HVO_1143 }\end{array}$ \\
\hline $7 \mathrm{~b}$ & HVO_0146 & asd & no & $39 \%$ & SMc00551 & Q9FDI9 & (Vences-Guzman et al., 2008) & 18708506 & $\begin{array}{l}\text { equivalent function for } \\
\text { the bacterial lipid }\end{array}$ \\
\hline $7 \mathrm{~b}$ & HVO_1295 & hisC & & self & & & (Conover and Doolittle, 1990) & 2345144 & $\begin{array}{l}\text { complements a His } \\
\text { auxotrophy mutant }\end{array}$ \\
\hline $7 \mathrm{~b}$ & $\begin{array}{l}\text { HVO_1295 } \\
\text { (cont.) }\end{array}$ & & yes & $31 \%$ & b2021 & P06986 & (Grisolia et al., 1985) & 2999081 & weak support, see text \\
\hline $7 \mathrm{~b}$ & HVO_1296 & $a d k 2$ & unclear & $34 \%$ & PAB0757 & Q9UZK4 & (Loc'h et al., 2014) & 24823650 & $\begin{array}{l}\text { Pyrococcus: involved } \\
\text { in ribosome biogenesis }\end{array}$ \\
\hline $7 \mathrm{~b}$ & $\begin{array}{l}\text { HVO_1296 } \\
\text { (cont.) }\end{array}$ & & unclear & $32 \%$ & - & Q9Y3D8 & (Ren et al., 2005) & 15630091 & $\begin{array}{l}\text { human: adenylate } \\
\text { kinase; HVO_1296 } \\
\text { may be inositol kinase }\end{array}$ \\
\hline $7 b$ & HVO_2496 & $a d k 1$ & yes & $45 \%$ & BSU01370 & P16304 & (Moon et al., 2019) & 31111079 & $\begin{array}{l}\text { Bacillus: adenylate } \\
\text { kinase }\end{array}$ \\
\hline $7 b$ & HVO_B0213 & - & yes & $43 \%$ & AF_1794 & $\mathrm{O} 28480$ & $\begin{array}{l}\text { (Chen et al., 2000) } \\
\text { (Neelon et al., 2011) }\end{array}$ & $\begin{array}{l}11015222 \\
22261071\end{array}$ & $\begin{array}{l}\text { Archaeoglobus: } \\
\text { adenylate kinase }\end{array}$ \\
\hline $7 b$ & HVO_1135 & - & - & & & & & & $\begin{array}{l}\text { a SAM-dependent } \\
\text { methyltransferase }\end{array}$ \\
\hline $7 \mathrm{c}$ & HVO_2524 & $c r t B$ & & self & & & $\begin{array}{l}\text { (Kiljunen et al., 2014) } \\
\text { (Maurer et al., 2018) }\end{array}$ & $\begin{array}{l}25488358 \\
29038254\end{array}$ & $\begin{array}{l}\text { crtB mutants are } \\
\text { colorless }\end{array}$ \\
\hline $7 \mathrm{c}$ & $\begin{array}{l}\text { HVO_2524 } \\
\text { (cont.) }\end{array}$ & & yes & $32 \%$ & $\begin{array}{l}\text { Synpcc7942 } \\
\text { _1984 }\end{array}$ & P37269 & (Chamovitz et al., 1992) & 1537409 & \\
\hline $7 \mathrm{c}$ & HVO_2527 & lyeJ & & self & & & (Dummer et al., 2011) & 21840984 & \\
\hline $7 \mathrm{c}$ & $\begin{array}{l}\text { HVO_2527 } \\
\text { (cont.) }\end{array}$ & & yes & $65 \%$ & $\begin{array}{l}\text { VNG_1682C } \\
\text { OE_3380R }\end{array}$ & $\begin{array}{l}\text { Q9HPD9 } \\
\text { B0R651 }\end{array}$ & (Dummer et al., 2011) & 21840984 & \\
\hline $7 \mathrm{c}$ & $\begin{array}{l}\text { HVO_2527 } \\
\text { (cont.) }\end{array}$ & & yes & $61 \%$ & C444_12922 & M0L7V9 & (Yang et al., 2015) & 25712483 & \\
\hline $7 \mathrm{c}$ & HVO_2528 & $c r t D$ & & self & & & (Maurer et al., 2018) & 29038254 & $\begin{array}{l}\text { a HVO_2528 mutant } \\
\text { was white }\end{array}$ \\
\hline $7 \mathrm{c}$ & $\begin{array}{l}\text { HVO_2528 } \\
\text { (cont.) }\end{array}$ & & yes & $71 \%$ & C444_12917 & A0A0A1GKA2 & (Yang et al., 2015) & 25712483 & \\
\hline $7 \mathrm{c}$ & HVO_2526 & cruF & yes & $59 \%$ & C444_12927 & A0A0A1GNF2 & (Yang et al., 2015) & 25712483 & \\
\hline
\end{tabular}




\begin{tabular}{|c|c|c|c|c|c|c|c|c|c|}
\hline $7 d$ & HVO_1470 & menF & yes & $38 \%$ & PA4231 & Q51508 & (Serino et al., 1995) & 7500944 & \\
\hline $7 d$ & HVO_1469 & menD & yes & $37 \%$ & BSU30820 & P23970 & (Dawson et al., 2010) & 20600129 & \\
\hline $7 d$ & pathway gap & & & & & & & & EC 4.2.99.20 \\
\hline $7 \mathrm{~d}$ & HVO_1461 & menC & no & $29 \%$ & BSU12980 & O34508 & (Schmidt et al., 2001) & 11747447 & Ala/Glu epimerase \\
\hline $7 d$ & $\begin{array}{l}\mathrm{HVO}_{\text {(cont. }} \text { ) } \\
\text { (461 }\end{array}$ & & yes & $24 \%$ & BSU30780 & $\mathrm{O} 34514$ & (Palmer et al., 1999) & 10194342 & $\begin{array}{l}\text { o-succinylbenzoate } \\
\text { synthase }\end{array}$ \\
\hline $7 d$ & HVO_1375 & menE & yes & $36 \%$ & BSU30790 & P23971 & (Chen et al., 2016) & 27933791 & \\
\hline $7 d$ & HVO_1465 & menB & yes & $66 \%$ & Rv0548c & P9WNP5 & (Jiang et al., 2010) & 20643650 & \\
\hline $7 d$ & pathway gap & & & & & & & & EC 3.1.2.28 \\
\hline $7 d$ & HVO_1462 & menA & yes & $37 \%$ & b3930 & P32166 & (Suvarna et al., 1998) & 9573170 & \\
\hline $7 d$ & HVO_0309 & menG & yes/no & $44 \%$ & At3g63410 & Q9LY74 & (Cheng et al., 2003) & 14508009 & $\begin{array}{l}\text { A.thaliana enzyme also } \\
\text { involved in tocopherol } \\
\text { biosynthesis }\end{array}$ \\
\hline $7 d$ & $\begin{array}{l}\text { HVO_0309 } \\
\text { (cont.) }\end{array}$ & & yes & $27 \%$ & - & O86169 & (Koike-Takeshita et al., 1997) & 9139683 & \\
\hline
\end{tabular}

637

638 Table 7: Proteins with open annotation issues and their Gold Standard Protein homologs (Section 7). For a description of this table see the

639 legend to Table 1. 
$640 \quad 3.8$ Issues concerning RNA polymerase, protein translation components and

641 signal peptide degradation

642 (a) Haloarchaeal RNA polymerase consists of a set of canonical subunits (encoded by 643 rpoA1A2B1B2DEFHKLNP). Hbt. salinarum and a subset of other haloarchaea 644 contain an additional subunit called epsilon (Leffers et al., 1989, Madon and Zillig, 645 1983). Purified RNA polymerase containing the epsilon subunit transcribes native 646 templates efficiently, in contrast to RNA polymerase devoid of this subunit (Madon 647 and Zillig, 1983). The biological relevance of this subunit is enigmatic (see 648 Suppl.Text S1 Section 8). (b) Two distant paralogs are found for haloarchaeal ribosomal protein $\mathrm{S} 10$ (uS10) in 651 nearly all haloarchaeal genomes. It is uncertain if both occur in the ribosome, whether 652 they occur together or are mutually exclusive. The latter distribution would result in 653 heterogeneity of the ribosomes. Alternatively, one of the paralogs may exclusively 654 have a non-ribosomal function.

In a subset of archaea, two distant paralogs are found for haloarchaeal ribosomal 657 protein S14 (uS14) (ca 20\% of the genomes, e.g. in Nmn. pharaonis). For more details see Suppl.Text S1 Section 8.

660 (c) The ribosomal protein L43e (eL43) shows heterogeneity with respect to the 661 present of C2-C2 type zinc finger motif. This zinc finger is found in L43e from all 662 Halobacteriales and all euryarchaeal proteins outside the order Halobacteria, but is 663 not found in Haloferacales and very rare in Natrialbales, . Eukaryotic orthologs (e.g. 664 from rat and yeast) contain this zinc finger and its biological importance has been 665 experimentally shown for the yeast protein (Rivlin et al., 1999) (for details see 666 Suppl.Text S1 Section 8).

668 (d) Diphthamide is a complex covalent modification of a histidine residue of 669 translation elongation factor a-EF2. The pathway has been reconstructed (Table 8), 670 based on distant homologs (enzymes encoded by $d p h 2, d p h 5)$ and by detailed 
671 bioinformatic analysis (enzyme encoded by dph6) (de Crecy-Lagard et al., 2012) (for

672 details see Suppl.Text S1 Section 8). These uncertain function assignments await

673 experimental confirmation.

674

675 (e) N-terminal signal sequences target proteins to the secretion machinery.

676 Subsequent to membrane insertion or transmembrane transfer, the signal sequence is

677 cleaved off by signal peptidase. After cleavage, the signal peptide must be degraded

678 to avoid clogging of the membrane. Degradation is catalyzed by signal peptide

679 peptidase. Candidates for this activity have been predicted from two protein families

680 (Ng et al., 2007, Raut et al., 2021) (for details see Suppl.Text S1 Section 8). 


\begin{tabular}{|c|c|c|c|c|c|c|c|c|c|}
\hline & & & & Gold & Standard Prot & & & & \\
\hline $\begin{array}{l}\text { Sectio } \\
\text { n }\end{array}$ & Code & Gene & isofunc & \%seq_id & Locus tag & UniProt & Reference & PMID & Comment \\
\hline $8 \mathrm{a}$ & OE_1279R & rpoeps & & self & & & $\begin{array}{l}\text { (Leffers et al., 1989) } \\
\text { (Madon and Zillig, 1983) }\end{array}$ & $\begin{array}{l}2495365 \\
6852054 \\
\end{array}$ & \\
\hline $8 \mathrm{~b}$ & HVO_0360 & rps10a & yes & $94 \%$ & rrnAC2405 & P23357 & (Arndt et al., 1991) & 1764513 & \\
\hline $8 \mathrm{~b}$ & HVO_1392 & $r p s 10 b$ & - & & & & & & $\begin{array}{l}\text { no GSP; } 24 \% \text { seq_id to } \\
\text { HVO_0360 (rpsiOa) }\end{array}$ \\
\hline $8 b$ & NP_4882A & $r p s 14 a$ & yes & $72 \%$ & rrnAC1597.1 & P26816 & (Scholzen and Arndt, 1991) & 1832208 & $\begin{array}{l}\text { full-length similarity; } \\
\text { Haloarcula } \\
\text { protein was not } \\
\text { isolated or } \\
\text { characterized }\end{array}$ \\
\hline $8 \mathrm{~b}$ & $\begin{array}{l}\text { NP_4882A } \\
\text { (cont.) }\end{array}$ & & yes & $57 \%$ & YDL061C & $\mathrm{P} 41058$ & (Otaka et al., 1984) & 18782943 & $\begin{array}{l}\text { yeast YS29B; } \\
\text { N-term } 20 \text { aa divergent }\end{array}$ \\
\hline $8 \mathrm{~b}$ & NP_1768A & $r p s 14 b$ & unclear & $80 \%$ & rrnAC1597.1 & P26816 & (Scholzen and Arndt, 1991) & 1832208 & N-term 20 aa divergent \\
\hline $8 \mathrm{c}$ & OE_1373R & rpl43e & yes & $69 \%$ & rrnAC1669 & P60619 & (Ban et al., 2000) & \begin{tabular}{|l|}
10937989 \\
\end{tabular} & \\
\hline $8 \mathrm{c}$ & $\begin{array}{l}\text { OE_1373R } \\
\text { (cont.) }\end{array}$ & & yes & $39 \%$ & YPR043W & P0CX25 & $\begin{array}{l}\text { (Rivlin et al., 1999) } \\
\text { (Dresios et al., 2002) }\end{array}$ & \begin{tabular}{|l|}
10588896 \\
11866512 \\
\end{tabular} & \\
\hline $8 \mathrm{c}$ & HVO_0654 & rpl43e & yes & $54 \%$ & rrnAC1669 & P60619 & (Ban et al., 2000) & 10937989 & $\begin{array}{l}\text { Haloarcula: has zinc } \\
\text { finger; } \\
\text { Haloferax; lacks zinc } \\
\text { finger }\end{array}$ \\
\hline $8 \mathrm{~d}$ & HVO_1631 & $d p h 2$ & yes & $35 \%$ & PH1105 & O58832 & (Zhu et al., 2011) & 20931132 & \\
\hline $8 \mathrm{~d}$ & HVO_0916 & $d p h 5$ & yes & $39 \%$ & PH0725 & O58456 & (Zhu et al., 2010) & 20873788 & \\
\hline $8 \mathrm{~d}$ & HVO_1077 & $d p h 6$ & yes & $31 \%$ & YLR143W & Q12429 & $\begin{array}{l}\text { (Su et al., 2012) } \\
\text { (Uthman et al., 2013) }\end{array}$ & \begin{tabular}{|l|}
23169644 \\
234686600
\end{tabular} & \\
\hline $8 \mathrm{e}$ & HVO_0881 & sppA1 & yes & $33 \%$ & BSU19530 & O34525 & $\begin{array}{l}\text { (Bolhuis et al., 1999) } \\
\text { (Nam et al., 2012) } \\
\end{array}$ & \begin{tabular}{|l|}
10455123 \\
22472423 \\
\end{tabular} & \\
\hline $8 \mathrm{e}$ & HVO_1987 & sppA2 & probably & $23 \%$ & BSU19530 & O34525 & $\begin{array}{l}\text { (Bolhuis et al., 1999) } \\
\text { (Nam et al., 2012) }\end{array}$ & \begin{tabular}{|l|}
10455123 \\
22472423 \\
\end{tabular} & \\
\hline $8 \mathrm{e}$ & HVO_1107 & - & prediction & & & & & & no GSP \\
\hline
\end{tabular}


685

686

687

688

689

690

691

692

693

694

695

696

697

698

699

700

701

702

703

704

705

706

707

708

709

\subsection{Miscellaneous metabolic enzymes and proteins with other functions}

Here, we list a few other enzymatic or non-enzymatic functions for which candidate genes have been assigned, but without experimental validation.

(a) Ketohexokinase from Haloarcula vallismortis has been experimentally

characterized (Rangaswamy and Altekar, 1994). However, the activity was not assigned to a gene. Detailed bioinformatic analyses have been made (Anderson et al., 2011, Williams et al., 2019) and point to a small set of orthologs represented by Hmuk_2662, the ortholog of HVO_1812 (for further details see Suppl. Text S1 Section 9).

(b) The assignment of fructokinase activity to the Hht. litchfieldiae candidate gene halTADL_1913 (UniProt:A0A1H6QYL4) is based on differential proteomic analysis (Williams et al., 2019) (see Suppl. Text S1 Section 9 for details). Very close homologs are rare in haloarchaea. For this protein family (carbohydrate kinase) it is unclear if more distant homologs (with about $50 \%$ protein sequence identity) are isofunctional.

(c) A candidate gene for glucoamylase is HVO_1711 for reasons described in Suppl. Text S1 Section 9. The enyzme from Halorubrum sodomense has been characterized (Chaga et al., 1993) but the activity was not yet assigned to a gene.

(d) A strong candidate for having glucose-6-phosphate isomerase activity is $H f x$. volcanii (HVO_1967, pgi), based on 36\% protein sequence identity to the characterized enzyme from M. jannaschii (MJ1605) (Rudolph et al., 2004) (Table 9). 


\begin{tabular}{|c|c|c|c|c|c|c|c|c|c|}
\hline & & & & Gold & Standard Pro & & & & \\
\hline $\begin{array}{l}\text { Sectio } \\
\text { n }\end{array}$ & Code & Gene & isofunc & \%seq_id & Locus tag & UniProt & Reference & PMID & Comment \\
\hline $9 \mathrm{a}$ & HVO_1812 & - & prediction & & & & & & no GSP \\
\hline $9 \mathrm{~b}$ & halTADL_1913 & - & yes & $37 \%$ & - & P26984 & (Aulkemeyer et al., 1991) & 1809835 & \\
\hline $9 \mathrm{~b}$ & $\begin{array}{l}\text { halTADL_1913 } \\
\text { (cont.) }\end{array}$ & - & yes & $31 \%$ & OCC_03567 & $\begin{array}{l}\text { Q7LYW8 } \\
\text { H3ZP68 }\end{array}$ & (Qu et al., 2004) & 15138858 & \\
\hline $9 \mathrm{c}$ & HVO_1711 & - & probably & $33 \%$ & - & P29761 & (Ohnishi et al., 1992) & 1633799 & $\begin{array}{l}\text { P29761 matches to C- } \\
\text { term half of } \\
\text { HVO_1711 }\end{array}$ \\
\hline $9 \mathrm{c}$ & $\begin{array}{l}\text { HVO_1711 } \\
\text { (cont.) }\end{array}$ & - & probably & $51 \%$ & \begin{tabular}{|l} 
SAMN \\
04487937 \\
2677
\end{tabular} & A0A1I6HD35 & (Chaga et al., 1993) & 8305855 & $\begin{array}{l}\text { correlation between } \\
\text { PMID:8305855 and } \\
\text { A0A1I6HD35 likely } \\
\text { (see text) }\end{array}$ \\
\hline $9 \mathrm{~d}$ & HVO_1967 & $p g i$ & yes & $36 \%$ & MJ1605 & Q59000 & (Rudolph et al., 2004) & 14655001 & \\
\hline $9 \mathrm{e}$ & OE_1665R & $k d g A$ & no & $31 \%$ & PA1010 & Q9I4W3 & (Kaur et al., 2011) & 21396954 & $\begin{array}{l}\text { GSP for dapA (see } \\
\text { under } 2 \mathrm{a} \text { ) }\end{array}$ \\
\hline $9 \mathrm{e}$ & $\begin{array}{l}\text { OE_1665R } \\
\text { (cont.) }\end{array}$ & & probably & $30 \%$ & $\begin{array}{l}\text { TTX_1156.1 } \\
\text { TTX_1156a }\end{array}$ & G4RJQ2 & (Ahmed et al., 2005) & 15869466 & \\
\hline $9 \mathrm{e}$ & $\begin{array}{l}\text { OE_1665R } \\
\text { (cont.) }\end{array}$ & & probably & $25 \%$ & SSO3197 & Q97U28 & (Ahmed et al., 2005) & 15869466 & \\
\hline 9f & HVO_1692 & $\operatorname{ludB}$ & & self & & & (Reinhardt et al., 2019) & 30707467 & \\
\hline $9 \mathrm{f}$ & 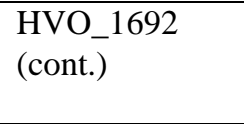 & & probably & $35 \%$ & BSU34040 & O07021 & (Chai et al., 2009) & 19201793 & $\begin{array}{l}\text { matches up to } \\
\text { HVO_1692 pos } 490 \text { of } \\
733\end{array}$ \\
\hline $9 \mathrm{f}$ & $\begin{array}{l}\text { HVO_1692 } \\
\text { (cont.) }\end{array}$ & & probably & $35 \%$ & PST_3338 & O4VPR6 & (Gao et al., 2015) & 25917905 & $\begin{array}{l}\text { matches up to } \\
\text { HVO_1692 pos } 400 \text { of } \\
733\end{array}$ \\
\hline $9 \mathrm{f}$ & HVO_1693 & ludC & & self & & & (Reinhardt et al., 2019) & 30707467 & \\
\hline $9 \mathrm{f}$ & $\begin{array}{l}\text { HVO_1693 } \\
\text { (cont.) }\end{array}$ & & probably & $30 \%$ & BSU34030 & O32259 & (Chai et al., 2009) & 19201793 & \\
\hline $9 \mathrm{f}$ & $\begin{array}{l}\text { HVO_1693 } \\
\text { (cont.) }\end{array}$ & & probably & $33 \%$ & PST_3339 & O4VPR7 & (Gao et al., 2015) & 25917905 & partial match \\
\hline 9f & HVO_1697 & - & unclear & $24 \%$ & PST_3340 & O4VPR8 & (Gao et al., 2015) & 25917905 & \\
\hline
\end{tabular}




\begin{tabular}{|c|c|c|c|c|c|c|c|c|c|}
\hline 9f & HVO_1696 & lctP & probably & $44 \%$ & PST_3336 & O4VPR4 & (Gao et al., 2015) & 25917905 & \\
\hline $9 g$ & HVO_B0300 & pucLl & yes & $49 \%$ & BSU32450 & O32141 & (Pfrimer et al., 2010) & 20168977 & $\begin{array}{l}\text { Bacillus: bifunctional, } \\
\text { matches to C-term }\end{array}$ \\
\hline $9 g$ & HVO_B0299 & pucM & yes & $43 \%$ & BSU32460 & O32142 & (Lee et al., 2005) & 16098976 & \\
\hline $9 g$ & HVO_B0301 & pucL2 & yes & $43 \%$ & BSU32450 & O32141 & (Kim et al., 2007) & 17567580 & $\begin{array}{l}\text { Bacillus: bifunctional, } \\
\text { matches to N-term }\end{array}$ \\
\hline $9 g$ & HVO_B0302 & pucHl & no & $33 \%$ & - & Q8VTT5 & (Xu et al., 2002) & 12148274 & $\begin{array}{l}\text { paper in Chinese, } \\
\text { abstract in English; } \\
\text { pyrimidine degradation }\end{array}$ \\
\hline $9 g$ & $\begin{array}{l}\text { HVO_B0302 } \\
\text { (cont.) }\end{array}$ & & yes & $30 \%$ & STM0523 & Q7CR08 & (Ho et al., 2013) & 23287969 & purine degradation \\
\hline $9 g$ & $\begin{array}{l}\text { HVO_B0302 } \\
\text { (cont.) }\end{array}$ & & yes & $29 \%$ & BSU32410 & O32137 & (Schultz et al., 2001) & 11344136 & purine degradation \\
\hline $9 g$ & HVO_B0306 & amaB4 & no & $39 \%$ & - & Q53389 & (Martinez-Rodriguez et al., 2012) & 22904279 & $\begin{array}{l}\text { carbamoyl-AA } \\
\text { hydrolysis }\end{array}$ \\
\hline $9 g$ & $\begin{array}{l}\text { HVO_B0306 } \\
\text { (cont.) }\end{array}$ & & yes & $34 \%$ & At5g43600 & Q8VXY9 & $\begin{array}{l}\text { (Werner et al., 2010) } \\
\text { (Werner et al., 2013) }\end{array}$ & $\begin{array}{l}19935661 \\
23940254 \\
\end{array}$ & purine degradation \\
\hline $9 g$ & HVO_B0308 & $\operatorname{coxS}$ & no & $46 \%$ & Saci_2270 & Q4J6M5 & (Kardinahl et al., 1999) & 10095793 & GAPDH \\
\hline $9 g$ & $\begin{array}{l}\text { HVO_B0308 } \\
\text { (cont.) }\end{array}$ & & no & $41 \%$ & - & P19915 & (Kang and Kim, 1999) & 10482497 & CO-DH \\
\hline $9 g$ & $\begin{array}{l}\text { HVO_B0308 } \\
\text { (cont.) }\end{array}$ & & yes & $39 \%$ & b2868 & Q46801 & (Xi et al., 2000) & 10986234 & xanthine DH \\
\hline $9 g$ & HVO_B0309 & $\operatorname{cox} L$ & yes & $33 \%$ & b2866 & Q46799 & (Xi et al., 2000) & 10986234 & xanthine DH \\
\hline $9 g$ & $\begin{array}{l}\text { HVO_B0309 } \\
\text { (cont.) }\end{array}$ & & no & $28 \%$ & - & P19913 & (Kang and Kim, 1999) & 10482497 & CO-DH \\
\hline $9 g$ & $\begin{array}{l}\text { HVO_B0309 } \\
\text { (cont.) }\end{array}$ & & no & $26 \%$ & Saci_2271 & Q4J6M3 & (Kardinahl et al., 1999) & 10095793 & GAPDH \\
\hline $9 g$ & HVO_B0310 & $\operatorname{cox} M$ & no & $31 \%$ & Saci_2269 & Q4J6M6 & (Kardinahl et al., 1999) & 10095793 & GAPDH \\
\hline $9 g$ & $\begin{array}{l}\text { HVO_B0310 } \\
\text { (cont.) }\end{array}$ & & no & $31 \%$ & - & P19914 & (Kang and Kim, 1999) & 10482497 & CO-DH \\
\hline $9 g$ & $\begin{array}{l}\text { HVO_B0310 } \\
\text { (cont.) }\end{array}$ & & yes & $25 \%$ & b2867 & Q46800 & (Xi et al., 2000) & 10986234 & xanthine DH \\
\hline $9 g$ & HVO_B0303 & uraA4 & yes & $38 \%$ & b3654 & P0AGM9 & (Karatza and Frillingos, 2005) & 16096267 & \\
\hline $9 \mathrm{~h}$ & HVO_0197 & - & possibly & $39 \%$ & lp_0105 & F9UST0 & (Desguin et al., 2016) & 27114550 & LarB family protein \\
\hline $9 \mathrm{~h}$ & HVO_2381 & - & possibly & $31 \%$ & lp_0106/ & F9UST1 & (Desguin et al., 2016) & 27114550 & LarC family protein \\
\hline
\end{tabular}




\begin{tabular}{|c|c|c|c|c|c|c|c|c|c|}
\hline & & & & & lp_0107 & & & & \\
\hline $9 \mathrm{~h}$ & HVO_0190 & - & possibly & $34 \%$ & lp_0109 & F9UST4 & (Desguin et al., 2016) & 27114550 & LarE family protein \\
\hline $9 \mathrm{i}$ & HVO_1660 & dacZ & & self & & & (Braun et al., 2019) & 30884174 & \\
\hline $9 \mathrm{i}$ & HVO_0756 & - & prediction & & & & (He et al., 2020) & 32095817 & \\
\hline $9 \mathrm{i}$ & HVO_0990 & - & prediction & & & & (He et al., 2020) & 32095817 & \\
\hline $9 \mathrm{i}$ & HVO_1690 & - & prediction & & & & (He et al., 2020) & 32095817 & \\
\hline $9 \mathrm{j}$ & HVO_2763 & - & & self & & & & 22350204 & $\begin{array}{l}\text { no function could be } \\
\text { assigned }\end{array}$ \\
\hline $9 \mathrm{j}$ & $\begin{array}{l}\text { HVO_2763 } \\
\text { (cont.) }\end{array}$ & & no & $27 \%$ & HVO_0144 & D4GZ88 & (Spath et al., 2008) & 18437358 & Rnase Z \\
\hline $9 \mathrm{k}$ & HVO_2410 & $d a b A$ & yes & $33 \%$ & Hneap_0211 & D0KWS7 & (Desmarais et al., 2019) & 31406332 & \\
\hline $9 \mathrm{k}$ & HVO_2411 & $d a b B$ & yes & $31 \%$ & Hneap_0212 & D0KWS8 & (Desmarais et al., 2019) & 31406332 & \\
\hline
\end{tabular}

712 Table 9: Proteins with open annotation issues and their Gold Standard Protein homologs (Section 9). For a description of this table see the

713 legend to Table 1. 
714 (e) A candidate gene for specifying an enzyme with 2-dehydro-3-deoxy-

715 (phospho)gluconate aldolase activity is Hbt. salinarum $k d g A$ (OE_1665R). It is rather

716 closely related (36\% protein sequence) to $H f x$, volcanii $\mathrm{HVO} \_1101$ (encoded by

$717 \operatorname{dapA}$ ), which is involved in lysine biosynthesis, a biosynthetic pathway that is absent

718 from Hbt. salinarum. The function assignment is based on distant homologs from

719 Saccharolobus (Sulfolobus) solfataricus and Thermoproteus tenax which have been

720 characterized (Ahmed et al., 2005) (for details see Suppl. Text S1 Section 9).

722 (f) Haloarchaea may contain an NAD-independent L-lactate dehydrogenase, LudBC

723 (HVO_1692 and HVO_1693). Deletion of this gene pair impairs growth on rhamnose,

724 which is catabolized to pyruvate and lactate (Reinhardt et al., 2019). There is a very

725 distant relationship (for details see Suppl.Text S1 Section 9) to the LldABC subunits

726 of the characterized L-lactate dehydrogenase from Pseudomonas stutzeri A1501 (Gao

727 et al., 2015) and to the LutABC proteins from B. subtilis, which have been shown to

728 be involved in lactose utilization (Chai et al., 2009).

730 (g) $H f x$. volcanii may be able to convert urate to allantoin, using the gene cluster

731 HVO_B0299-HVO_B0302. This could be part of a complete degradation pathway for

732 purines, which, however, has to be considered highly speculative (see Suppl.Text S1

733 Section 9).

735 (h) $H f x$. volcanii may contain an enzyme having a "nickel-pincer cofactor". The

736 biogenesis of this cofactor may be catalyzed by larBCE (as detailed in Suppl. Text S1

737 Section 9).

739 (i) cyclic diguanylate hydrolysis

740 Cyclic di-AMP (c-di-AMP) is an important nucleotide signalling molecule in bacteria

741 and archaea. It is generated from two molecules of ATP by diadenylate cyclase

742 (encoded by dacZ) and is degraded to pApA by phosphodiesterases (Corrigan and

743 Grundling, 2013). The level of this signalling molecule is strictly controlled

744 (Gundlach et al., 2015, Commichau et al., 2019), thus requiring a sophisticated

745 interplay of cyclase and phosphodiesterase. DacZ from $H f x$. volcanii has been 
746 characterized and it was shown that c-di-AMP levels must be tightly regulated (Braun

747 et al., 2019). The degrading enzyme, however, has not yet been identified in

748 Haloferax but candidates have been proposed (Corrigan and Grundling, 2013, He et

749 al., 2020, Yin et al., 2020) (see Suppl. Text S1 Section 9).

751 (j) homolog to RNaseZ

752 HVO_2763 is distantly related to RNase Z (HVO_0144, rnz). The experimental 753 characterization of HVO_2763 (Fischer et al., 2012) excluded activity as exonuclease

754 but did not reveal its physiological function. Upon transcriptome analysis, the

755 downregulation of several genes was detected. Several of these were uncharacterized

756 at the time of the experiment but have since been shown to be involved in the minor

$757 \mathrm{~N}$-glycosylation pathway that was initially detected under low salt conditions (see

758 Suppl. Text S1 Section 9 for further details) .

760 (k) A pair of genes $\left(\right.$ dabAB) is predicted to function as $\mathrm{CO}_{2}$ transporter.

761 HVO_2410 and HVO_2411 probably function as carbon dioxide transporter, based on 762 the identification of such transporters in Halothiobacillus neapolitanus (Desmarais et 763 al., 2019). Being a member of the proton-conducting membrane transporter family, 764 this protein may be misannotated as a subunit of the nuo or mrp complex (see Suppl.

765 Text S1 Section 9 for further details).

\section{Conclusion}

768 We describe a large number of cases where protein function cannot be correctly 769 predicted when restricting considerations to computational analyses without taking 770 the biological context into account. An example is the switch from methanopterin to 771 tetrahydrofolate as $\mathrm{C} 1$ carrier in haloarchaea. Homologous enzymes, inherited from 772 the common ancestor, have adapted to the new $\mathrm{C} 1$ carrier, rather being replaced by 773 non-homologous proteins. Function prediction tools may misannotate haloarchaeal 774 proteins to work with methanopterin. Another example is the nио complex and its 775 misannotation as a type I NADH dehydrogenase. In other cases, even distant sequence 776 similarity may allow a valid function prediction if additional evidence (e.g. from gene 
777 neighbourhood analysis or from detailed evaluation of metabolic pathway gaps) is

778 taken into account. Examples include cobalamin cluster proteins, which probably

779 close the two residual pathway gaps, and the predicted degradation pathway for

780 purines. In all these cases, we have presented reasonable hypotheses based on current

781 knowledge, and in many cases these are so well supported as to be compelling, but to

782 be certain, experimental data are required. With this overview, we attempt to arouse

783 the curiosity of colleagues, hoping that they will confirm or disprove our speculations

784 and thus advance the knowledge about haloarchaeal biology. $H f x$. volcanii is a model

785 species for halophilic archaea, and the more complete and correctly its genome is

786 annotated, the higher will be its value for systems biology analyses (modelling) and

787 for synthetic biology (metabolic engineering) and biotechnology. 
788

789

790

791

792

793

794

801 This research received no specific grant from any funding agency in the public,

802 commercial, or non-for-profit sectors.

\section{Acknowledgments}

We thank all members of the Haloferax community for more than a decade of fruitful cooperation and for sharing their deep knowledge about the biology of this model species. We thank our colleagues for kindly reading and providing thoughtful comments on the manuscript before submission: Sonja-Verena Albers, Thorsten Allers, Maria Jose Bonete, Rosana de Castro, Sebastien Ferreira-Cerca, Anita Marchfelder, Mechthild Pohlschroder, Joerg Soppa. We thank Birgit Scharf for insightful discussions on the Natronomonas respiratory chain.

803

804 Authors contribution

805 Conceptualization, F.P.

806 Data curation, F.P.

807 Project administration, F.P.

808 Formal analysis, F.P., M.D-S.

809 Investigation F.P., M.D-S.

810 Validation, F.P., M.D-S.

811 Visualization, F.P., M.D-S.

812 Writing - original draft, F.P., M.D-S.;

813 Writing - review \& editing, F.P., M.D-S.

\section{Conflict of interest}

$816 \quad$ None declared. 
bioRxiv preprint doi: https://doi.org/10.1101/2021.05.03.442417; this version posted May 16, 2021. The copyright holder for this preprint (which was not certified by peer review) is the author/funder, who has granted bioRxiv a license to display the preprint in perpetuity. It is made available under aCC-BY-NC-ND 4.0 International license.

817

\section{$818 \quad$ Ethics statement}

819 Not applicable 


\section{REFERENCES}

ABDUL HALIM, M. F., PFEIFFER, F., ZOU, J., FRISCH, A., HAFT, D., WU, S., TOLIC, N., BREWER, H., PAYNE, S. H., PASA-TOLIC, L. \& POHLSCHRODER, M. 2013. Haloferax volcanii archaeosortase is required for motility, mating, and C-terminal processing of the S-layer glycoprotein. Mol Microbiol, 88, 1164-75.

ABDUL HALIM, M. F., RODRIGUEZ, R., STOLTZFUS, J. D., DUGGIN, I. G. \& POHLSCHRODER, M. 2018. Conserved residues are critical for Haloferax volcanii archaeosortase catalytic activity: Implications for convergent evolution of the catalytic mechanisms of non-homologous sortases from archaea and bacteria. Mol Microbiol, 108, 276-87.

ABDUL-HALIM, M. F., SCHULZE, S., DILUCIDO, A., PFEIFFER, F., BISSON FILHO, A. W. \& POHLSCHRODER, M. 2020. Lipid anchoring of archaeosortase substrates and midcell growth in haloarchaea. mBio, 11, e00349-20.

AHMED, H., ETTEMA, T. J., TJADEN, B., GEERLING, A. C., VAN DER OOST, J. \& SIEBERS, B. 2005. The semi-phosphorylative Entner-Doudoroff pathway in hyperthermophilic archaea: a re-evaluation. Biochem J, 390, 529-40.

AL-MAILEM, D. M., HOUGH, D. W. \& DANSON, M. J. 2008. The 2-oxoacid dehydrogenase multienzyme complex of Haloferax volcanii. Extremophiles, 12, 89-96.

ALLERS, T., BARAK, S., LIDDELL, S., WARDELL, K. \& MEVARECH, M. 2010. Improved strains and plasmid vectors for conditional overexpression of Histagged proteins in Haloferax volcanii. Appl Environ Microbiol, 76, 1759-69.

ALLERS, T. \& MEVARECH, M. 2005. Archaeal genetics - the third way. Nat. Rev. Genet., 6, 58-73.

ALTSCHUL, S. F., MADDEN, T. L., SCHAFFER, A. A., ZHANG, J., ZHANG, Z., MILLER, W. \& LIPMAN, D. J. 1997. Gapped BLAST and PSI-BLAST: a new generation of protein database search programs. Nucleic Acids Res, 25, 3389-402.

AMMElBuRG, M., haRTMANN, M. D., DJURANOVIC, S., ALVA, V., KORETKE, K. K., MARTIN, J., SAUER, G., TRUFFAULT, V., ZETH, K., LUPAS, A. N. \& COLES, M. 2007. A CTP-dependent archaeal riboflavin kinase forms a bridge in the evolution of cradle-loop barrels. Structure, 15, 1577-90.

ANDERSON, I., SCHEUNER, C., GOKER, M., MAVROMATIS, K., HOOPER, S. D., PORAT, I., KLENK, H. P., IVANOVA, N. \& KYRPIDES, N. 2011. Novel 
857

858

859

860

861

862

863

864

865

866

867

868

869

870

871

872

873

874

875

876

877

878

879

880

881

882

883

884

885

886

887

888

889

890

891

892

insights into the diversity of catabolic metabolism from ten haloarchaeal genomes. PLoS One, 6, e20237.

ARNDT, E., SCHOLZEN, T., KROMER, W., HATAKEYAMA, T. \& KIMURA, M. 1991. Primary structures of ribosomal proteins from the archaebacterium Halobacterium marismortui and the eubacterium Bacillus stearothermophilus. Biochimie, 73, 657-68.

AUFHAMMER, S. W., WARKENTIN, E., BERK, H., SHIMA, S., THAUER, R. K. \& ERMLER, U. 2004. Coenzyme binding in F420-dependent secondary alcohol dehydrogenase, a member of the bacterial luciferase family. Structure, 12, 361-70.

AULKEMEYER, P., EBNER, R., HEILENMANN, G., JAHREIS, K., SCHMID, K., WRIEDEN, S. \& LENGELER, J. W. 1991. Molecular analysis of two fructokinases involved in sucrose metabolism of enteric bacteria. $\mathrm{Mol}$ Microbiol, 5, 2913-22.

BABSKI, J., MAIER, L. K., HEYER, R., JASCHINSKI, K., PRASSE, D., JAGER, D., RANDAU, L., SCHMITZ, R. A., MARCHFELDER, A. \& SOPPA, J. 2014. Small regulatory RNAs in Archaea. RNA Biol, 11, 484-93.

BALE, N. J., SOROKIN, D. Y., HOPMANS, E. C., KOENEN, M., RIJPSTRA, W. I. C., VILLANUEVA, L., WIENK, H. \& SINNINGHE DAMSTE, J. S. 2019. New insights into the polar lipid composition of extremely halo(alkali)philic euryarchaea from hypersaline lakes. Front Microbiol, 10, 377.

BALI, S., LAWRENCE, A. D., LOBO, S. A., SARAIVA, L. M., GOLDING, B. T., PALMER, D. J., HOWARD, M. J., FERGUSON, S. J. \& WARREN, M. J. 2011. Molecular hijacking of siroheme for the synthesis of heme and $\mathrm{d} 1$ heme. Proc Natl Acad Sci U S A, 108, 18260-5.

BAN, N., NISSEN, P., HANSEN, J., MOORE, P. B. \& STEITZ, T. A. 2000. The complete atomic structure of the large ribosomal subunit at $2.4 \mathrm{~A}$ resolution. Science, 289, 905-20.

BASHIRI, G., ANTONEY, J., JIRGIS, E. N. M., SHAH, M. V., NEY, B., COPP, J., STUTELEY, S. M., SREEBHAVAN, S., PALMER, B., MIDDLEDITCH, M., TOKURIKI, N., GREENING, C., SCOTT, C., BAKER, E. N. \& JACKSON, C. J. 2019. A revised biosynthetic pathway for the cofactor F420 in prokaryotes. Nat Commun, 10, 1558.

BOLHUIS, A., MATZEN, A., HYYRYLAINEN, H. L., KONTINEN, V. P., MEIMA, R., CHAPUIS, J., VENEMA, G., BRON, S., FREUDL, R. \& VAN DIJL, J. M. 1999. Signal peptide peptidase- and ClpP-like proteins of Bacillus subtilis required 
893

894

895

896

897

898

899

900

901

902

903

904

905

906

907

908

909

910

911

912

913

914

915

916

917

918

919

920

921

922

923

924

925

926

927

928

for efficient translocation and processing of secretory proteins. J Biol Chem, 274, 24585-92.

BRAGA, D., LAST, D., HASAN, M., GUO, H., LEICHNITZ, D., UZUM, Z., RICHTER, I., SCHALK, F., BEEMELMANNS, C., HERTWECK, C. \& LACKNER, G. 2019. Metabolic pathway rerouting in Paraburkholderia rhizoxinica evolved long-overlooked derivatives of coenzyme F420. ACS Chem Biol, 14, 2088-94.

BRASEN, C. \& SCHONHEIT, P. 2001. Mechanisms of acetate formation and acetate activation in halophilic archaea. Arch Microbiol, 175, 360-8.

BRAUN, F., THOMALLA, L., VAN DER DOES, C., QUAX, T. E. F., ALLERS, T., KAEVER, V. \& ALBERS, S. V. 2019. Cyclic nucleotides in archaea: Cyclic diAMP in the archaeon Haloferax volcanii and its putative role. Microbiologyopen, 8, e00829.

BRAUN, M., BUNGERT, S. \& FRIEDRICH, T. 1998. Characterization of the overproduced NADH dehydrogenase fragment of the NADH:ubiquinone oxidoreductase (complex I) from Escherichia coli. Biochemistry, 37, 1861-7.

BRINDLEY, A. A., RAUX, E., LEECH, H. K., SCHUBERT, H. L. \& WARREN, M. J. 2003. A story of chelatase evolution: identification and characterization of a small 13-15-kDa "ancestral" cobaltochelatase (CbiXS) in the archaea. J Biol Chem, 278, 22388-95.

BRUDLER, R., HITOMI, K., DAIYASU, H., TOH, H., KUCHO, K.-I., ISHIURA, M., KANEHISA, M., ROBERTS, V. A., TODO, T., TAINER, J. A. \& GETZOFF, E. D. 2003. Identification of a new cryptochrome class. Molecular Cell, 11, 5967.

BRUSHABER, K. R., O'TOOLE, G. A. \& ESCALANTE-SEMERENA, J. C. 1998. CobD, a novel enzyme with L-threonine-O-3-phosphate decarboxylase activity, is responsible for the synthesis of (R)-1-amino-2-propanol O-2phosphate, a proposed new intermediate in cobalamin biosynthesis in Salmonella typhimurium LT2. J Biol Chem, 273, 2684-91.

BUAN, N. R., REHFELD, K. \& ESCALANTE-SEMERENA, J. C. 2006. Studies of the CobA-type ATP:Co(I)rrinoid adenosyltransferase enzyme of Methanosarcina mazei strain Go1. J Bacteriol, 188, 3543-50.

CAFORIO, A. \& DRIESSEN, A. J. M. 2017. Archaeal phospholipids: Structural properties and biosynthesis. Biochim Biophys Acta Mol Cell Biol Lipids, 1862, 1325-39.

CAO, S., HEPOWIT, N. \& MAUPIN-FURLOW, J. A. 2015. Ubiquitin-like protein SAMP1 and JAMM/MPN+ metalloprotease HvJAMM1 constitute a system for 
reversible regulation of metabolic enzyme activity in Archaea. PLoS One, 10, e0128399.

CERLETTI, M., MARTINEZ, M. J., GIMENEZ, M. I., SASTRE, D. E., PAGGI, R. A. \& DE CASTRO, R. E. 2014. The LonB protease controls membrane lipids composition and is essential for viability in the extremophilic haloarchaeon Haloferax volcanii. Environ Microbiol, 16, 1779-92.

CERletTI, M., PAGGI, R., TROETSCHEL, C., FERRARI, M. C., GUEVARA, C. R., ALBAUM, S., POETSCH, A. \& DE CASTRO, R. 2018. LonB protease is a novel regulator of carotenogenesis controlling degradation of phytoene synthase in Haloferax volcanii. J Proteome Res, 17, 1158-71.

CHAGA, G., PORATH, J. \& ILLENI, T. 1993. Isolation and purification of amyloglucosidase from Halobacterium sodomense. Biomed Chromatogr, 7, 256-61.

CHAI, Y., KOLTER, R. \& LOSICK, R. 2009. A widely conserved gene cluster required for lactate utilization in Bacillus subtilis and its involvement in biofilm formation. J Bacteriol, 191, 2423-30.

CHAMOVITZ, D., MISAWA, N., SANDMANN, G. \& HIRSCHBERG, J. 1992. Molecular cloning and expression in Escherichia coli of a cyanobacterial gene coding for phytoene synthase, a carotenoid biosynthesis enzyme. FEBS Letters, 296, 305-10.

CHEN, L., ZHOU, C., YANG, H. \& ROBERTS, M. F. 2000. Inositol-1-phosphate synthase from Archaeoglobus fulgidus is a class II aldolase. Biochemistry, 39, 12415-23.

CHEN, Y., JIANG, Y. \& GUO, Z. 2016. Mechanistic insights from the crystal structure of Bacillus subtilis o-succinylbenzoyl-CoA synthetase complexed with the adenylate intermediate. Biochemistry, 55, 6685-95.

CHENG, Z., SATTLER, S., MAEDA, H., SAKURAGI, Y., BRYANT, D. A. \& DELLAPENNA, D. 2003. Highly divergent methyltransferases catalyze a conserved reaction in tocopherol and plastoquinone synthesis in cyanobacteria and photosynthetic eukaryotes. Plant Cell, 15, 2343-56.

COHEN-KUPIEC, R., KUPIEC, M., SANDBECK, K. \& LEIGH, J. A. 1999. Functional conservation between the argininosuccinate lyase of the archaeon Methanococcus maripaludis and the corresponding bacterial and eukaryal genes. FEMS Microbiol Lett, 173, 231-8.

COLLINS, M., AFOLAYAN, S., IGIRANEZA, A. B., SCHILLER, H., KRESPAN, E., BEITING, D. P., DYALL-SMITH, M., PFEIFFER, F. \& POHLSCHRODER, M. 2020. Mutations affecting HVO_1357 or HVO_2248 cause hypermotility in 
966

967

968

969

970

971

972

973

974

975

976

977

978

979

980

981

982

983

984

985

986

987

988

989

990

991

992

993

994

995

996

997

998

999

1000

1001

1002

Haloferax volcanii, suggesting roles in motility regulation. Genes (Basel), 12, 58.

COMMICHAU, F. M., HEIDEMANN, J. L., FICNER, R. \& STULKE, J. 2019. Making and breaking of an essential poison: the cyclases and phosphodiesterases that produce and degrade the essential second messenger cyclic di-AMP in bacteria. J Bacteriol, 201, e00462-18.

CONOVER, R. K. \& DOOLITTLE, W. F. 1990. Characterization of a gene involved in histidine biosynthesis in Halobacterium (Haloferax) volcanii: isolation and rapid mapping by transformation of an auxotroph with cosmid DNA. $J$ Bacteriol, 172, 3244-9.

CORRIGAN, R. M. \& GRUNDLING, A. 2013. Cyclic di-AMP: another second messenger enters the fray. Nat Rev Microbiol, 11, 513-24.

COSTA, M. I., CERLETTI, M., PAGGI, R. A., TROTSCHEL, C., DE CASTRO, R. E., POETSCH, A. \& GIMENEZ, M. I. 2018. Haloferax volcanii proteome response to deletion of a rhomboid protease gene. J Proteome Res, 17, 961-77.

CROFTS, A. R., HONG, S., WILSON, C., BURTON, R., VICTORIA, D., HARRISON, C. \& SCHULTEN, K. 2013. The mechanism of ubihydroquinone oxidation at the Qo-site of the cytochrome bc1 complex. Biochim Biophys Acta, 1827, 1362-77.

DANCHIN, A., OUZOUNIS, C., TOKUYASU, T. \& ZUCKER, J. D. 2018. No wisdom in the crowd: genome annotation in the era of big data - current status and future prospects. Microb Biotechnol, 11, 588-605.

DAWSON, A., CHEN, M., FYFE, P. K., GUO, Z. \& HUNTER, W. N. 2010. Structure and reactivity of Bacillus subtilis MenD catalyzing the first committed step in menaquinone biosynthesis. $J$ Mol Biol, 401, 253-64.

DAWSON, K. S., FREEMAN, K. H. \& MACALADY, J. L. 2012. Molecular characterization of core lipids from halophilic archaea grown under different salinity conditions. Organic Geochemistry, 48, 1-8.

DE CRECY-LAGARD, V. 2014. Variations in metabolic pathways create challenges for automated metabolic reconstructions: Examples from the tetrahydrofolate synthesis pathway. Comput Struct Biotechnol J, 10, 41-50.

DE CRECY-LAGARD, V., FOROUHAR, F., BROCHIER-ARMANET, C., TONG, L. \& HUNT, J. F. 2012. Comparative genomic analysis of the DUF71/COG2102 family predicts roles in diphthamide biosynthesis and B12 salvage. Biol Direct, 7, 32.

DE, R. M. \& GAMBACORTA, A. 1988. The lipids of archaebacteria. Prog Lipid Res, 27, 153-75. 
1003

1004

1005

1006

1007

1008

1009

1010

1011

1012

1013

1014

1015

1016

1017

1018

1019

1020

1021

1022

1023

1024

1025

1026

1027

1028

1029

1030

1031

1032

1033

1034

1035

1036

1037

1038

1039

DE SILVA, R. T., ABDUL-HALIM, M. F., PITTRICH, D. A., BROWN, H. J., POHLSCHRODER, M. \& DUGGIN, I. G. 2021. Improved growth and morphological plasticity of Haloferax volcanii. Microbiology (Reading), 167.

DE WIT, L. E. A. \& EKER, A. P. M. 1987. 8-Hydroxy-5-deazaflavin-dependent electron transfer in the extreme halophile Halobacterium cutirubrum. FEMS Microbiology Letters, 48, 121-25.

DEBUSSCHE, L., COUDER, M., THIBAUT, D., CAMERON, B., CROUZET, J. \& BLANCHE, F. 1992. Assay, purification, and characterization of cobaltochelatase, a unique complex enzyme catalyzing cobalt insertion in hydrogenobyrinic acid a,c-diamide during coenzyme B12 biosynthesis in Pseudomonas denitrificans. J Bacteriol, 174, 7445-51.

DECAMPS, L., PHILMUS, B., BENJDIA, A., WHITE, R., BEGLEY, T. P. \& BERTEAU, O. 2012. Biosynthesis of F0, precursor of the F420 cofactor, requires a unique two radical-SAM domain enzyme and tyrosine as substrate. J Am Chem Soc, 134, 18173-6.

DENDA, K., FUJIWARA, T., SEKI, M., YOSHIDA, M., FUKUMORI, Y. \& YAMANAKA, T. 1991. Molecular cloning of the cytochrome aa3 gene from the archaeon (Archaebacterium) Halobacterium halobium. Biochem Biophys Res Commun, 181, 316-22.

DENG, H., BOTTING, C. H., HAMILTON, J. T., RUSSELL, R. J. \& O'HAGAN, D. 2008. S-adenosyl-L-methionine:hydroxide adenosyltransferase: a SAM enzyme. Angew Chem Int Ed Engl, 47, 5357-61.

DESGUIN, B., SOUMILLION, P., HOLS, P. \& HAUSINGER, R. P. 2016. Nickelpincer cofactor biosynthesis involves LarB-catalyzed pyridinium carboxylation and LarE-dependent sacrificial sulfur insertion. Proc Natl Acad Sci U S A, 113, 5598-603.

DESMARAIS, J. J., FLAMHOLZ, A. I., BLIKSTAD, C., DUGAN, E. J., LAUGHLIN, T. G., OLTROGGE, L. M., CHEN, A. W., WETMORE, K., DIAMOND, S., WANG, J. Y. \& SAVAGE, D. F. 2019. DABs are inorganic carbon pumps found throughout prokaryotic phyla. Nat Microbiol, 4, 2204-15.

DRESIOS, J., CHAN, Y. L. \& WOOL, I. G. 2002. The role of the zinc finger motif and of the residues at the amino terminus in the function of yeast ribosomal protein YL37a. J Mol Biol, 316, 475-88.

DUGGIN, I. G., AYLETT, C. H., WALSH, J. C., MICHIE, K. A., WANG, Q., TURNBULL, L., DAWSON, E. M., HARRY, E. J., WHITCHURCH, C. B., AMOS, L. A. \& LOWE, J. 2015. CetZ tubulin-like proteins control archaeal cell shape. Nature, 519, 362-5. 
1040

1041

1042

1043

1044

1045

1046

1047

1048

1049

1050

1051

1052

1053

1054

1055

1056

1057

1058

1059

1060

1061

1062

1063

1064

1065

1066

1067

1068

1069

1070

1071

1072

1073

1074

1075

1076

DUMITRU, R. V. \& RAGSDALE, S. W. 2004. Mechanism of 4-(beta-Dribofuranosyl)aminobenzene 5'-phosphate synthase, a key enzyme in the methanopterin biosynthetic pathway. J Biol Chem, 279, 39389-95.

DUMMER, A. M., BONSALL, J. C., CIHLA, J. B., LAWRY, S. M., JOHNSON, G. C. \& PECK, R. F. 2011. Bacterioopsin-mediated regulation of bacterioruberin biosynthesis in Halobacterium salinarum. J Bacteriol, 193, 5658-67.

EL YACOUBI, B., PHILLIPS, G., BLABY, I. K., HAAS, C. E., CRUZ, Y., GREENBERG, J. \& DE CRECY-LAGARD, V. 2009. A Gateway platform for functional genomics in Haloferax volcanii: deletion of three tRNA modification genes. Archaea, 2, 211-9.

ELLING, F. J., BECKER, K. W., KONNEKE, M., SCHRODER, J. M., KELLERMANN, M. Y., THOMM, M. \& HINRICHS, K. U. 2016. Respiratory quinones in Archaea: phylogenetic distribution and application as biomarkers in the marine environment. Environ Microbiol, 18, 692-707.

EUSTAQUIO, A. S., HARLE, J., NOEL, J. P. \& MOORE, B. S. 2008. S-Adenosyl-Lmethionine hydrolase (adenosine-forming), a conserved bacterial and archaeal protein related to SAM-dependent halogenases. Chembiochem, 9, 2215-9.

FAEHNLE, C. R., OHREN, J. F. \& VIOLA, R. E. 2005. A new branch in the family: structure of aspartate-beta-semialdehyde dehydrogenase from Methanococcus jannaschii. J Mol Biol, 353, 1055-68.

FALB, M., MULLER, K., KONIGSMAIER, L., OBERWINKLER, T., HORN, P., VON GRONAU, S., GONZALEZ, O., PFEIFFER, F., BORNBERG-BAUER, E. \& OESTERHELT, D. 2008. Metabolism of halophilic archaea. Extremophiles, 12, 177-96.

FALB, M., PFEIFFER, F., PALM, P., RODEWALD, K., HICKMANN, V., TITTOR, J. \& OESTERHELT, D. 2005. Living with two extremes: conclusions from the genome sequence of Natronomonas pharaonis. Genome Res, 15, 1336-43.

FISCHER, M., ROMISCH, W., SCHIFFMANN, S., KELLY, M., OSCHKINAT, H., STEINBACHER, S., HUBER, R., EISENREICH, W., RICHTER, G. \& BACHER, A. 2002. Biosynthesis of riboflavin in archaea studies on the mechanism of 3,4-dihydroxy-2-butanone-4-phosphate synthase of Methanococcus jannaschii. J Biol Chem, 277, 41410-6.

FISCHER, S., JOHN VON FREYEND, S., SABAG-DAIGLE, A., DANIELS, C. J., ALLERS, T. \& MARCHFELDER, A. 2012. Assigning a function to a conserved archaeal metallo-beta-lactamase from Haloferax volcanii. Extremophiles, 16, 333-43. 
1077

1078

1079

1080

1081

1082

1083

1084

1085

1086

1087

1088

1089

1090

1091

1092

1093

1094

1095

1096

1097

1098

1099

1100

1101

1102

1103

1104

1105

1106

1107

1108

1109

1110

1111

1112

FONSECA, M. V., BUAN, N. R., HORSWILL, A. R., RAYMENT, I. \& ESCALANTESEMERENA, J. C. 2002. The ATP:Co(I)rrinoid adenosyltransferase (CobA) enzyme of Salmonella enterica requires the 2'-OH group of ATP for function and yields inorganic triphosphate as its reaction byproduct. J Biol Chem, 277, 33127-31.

FOROUHAR, F., ABASHIDZE, M., XU, H., GROCHOWSKI, L. L., SEETHARAMAN, J., HUSSAIN, M., KUZIN, A., CHEN, Y., ZHOU, W., XIAO, R., ACTON, T. B., MONTELIONE, G. T., GALINIER, A., WHITE, R. H. \& TONG, L. 2008. Molecular insights into the biosynthesis of the F420 coenzyme. J Biol Chem, 283, $11832-40$.

FRESQUET, V., WILLIAMS, L. \& RAUSHEL, F. M. 2004. Mechanism of cobyrinic acid a,c-diamide synthetase from Salmonella typhimurium LT2. Biochemistry, 43, 10619-27.

FUJITA, S., CHO, S. H., YOSHIDA, A., HASEBE, F., TOMITA, T., KUZUYAMA, T. \& NISHIYAMA, M. 2017. Crystal structure of LysK, an enzyme catalyzing the last step of lysine biosynthesis in Thermus thermophilus, in complex with lysine: Insight into the mechanism for recognition of the amino-group carrier protein, LysW. Biochem Biophys Res Commun, 491, 409-15.

FUJIWARA, T., FUKUMORI, Y. \& YAMANAKA, T. 1989. Purification and properties of Halobacterium halobium "cytochrome aa3" which lacks CuA and CuB. J Biochem (Tokyo), 105, 287-92.

GAO, C., WANG, Y., ZHANG, Y., LV, M., DOU, P., XU, P. \& MA, C. 2015. NADindependent $L$-lactate dehydrogenase required for L-lactate utilization in Pseudomonas stutzeri A1501. J Bacteriol, 197, 2239-47.

GIANI, M., MIRALLES-ROBLEDILLO, J. M., PEIRO, G., PIRE, C. \& MARTINEZESPINOSA, R. M. 2020. Deciphering pathways for carotenogenesis in haloarchaea. Molecules, 25, 1197.

GRADIN, C. H., HEDERSTEDT, L. \& BALTSCHEFFSKY, H. 1985. Soluble succinate dehydrogenase from the halophilic archaebacterium, Halobacterium halobium. Arch Biochem Biophys, 239, 200-5.

GRAHAM, D. E., XU, H. \& WHITE, R. H. 2002. A member of a new class of GTP cyclohydrolases produces formylaminopyrimidine nucleotide monophosphates. Biochemistry, 41, 15074-84.

GRAHAM, D. E., XU, H. \& WHITE, R. H. 2003. Identification of the 7,8-didemethyl-8hydroxy-5-deazariboflavin synthase required for coenzyme $F(420)$ biosynthesis. Arch Microbiol, 180, 455-64. 
1113

1114

1115

1116

1117

1118

1119

1120

1121

1122

1123

1124

1125

1126

1127

1128

1129

1130

1131

1132

1133

1134

1135

1136

1137

1138

1139

1140

1141

1142

1143

1144

1145

1146

1147

1148

GRAUPNER, M., XU, H. \& WHITE, R. H. 2002a. Characterization of the 2-phosphoL-lactate transferase enzyme involved in coenzyme $\mathrm{F}(420)$ biosynthesis in Methanococcus jannaschii. Biochemistry, 41, 3754-61.

GRAUPNER, M., XU, H. \& WHITE, R. H. 2002b. The pyrimidine nucleotide reductase step in riboflavin and $F(420)$ biosynthesis in archaea proceeds by the eukaryotic route to riboflavin. J Bacteriol, 184, 1952-7.

GRISOLIA, V., CARLOMAGNO, M. S., NAPPO, A. G. \& BRUNI, C. B. 1985. Cloning, structure, and expression of the Escherichia coli K-12 hisC gene. J Bacteriol, 164, 1317-23.

GROCHOWSKI, L. L., XU, H., LEUNG, K. \& WHITE, R. H. 2007. Characterization of an Fe(2+)-dependent archaeal-specific GTP cyclohydrolase, MptA, from Methanocaldococcus jannaschii. Biochemistry, 46, 6658-67.

GROCHOWSKI, L. L., XU, H. \& WHITE, R. H. 2008. Identification and characterization of the 2-phospho-L-lactate guanylyltransferase involved in coenzyme F420 biosynthesis. Biochemistry, 47, 3033-7.

GULKO, M. K., DYALL-SMITH, M., GONZALEZ, O. \& OESTERHELT, D. 2014. How do haloarchaea synthesize aromatic amino acids? PLoS One, 9, e107475.

GUNDLACH, J., MEHNE, F. M., HERZBERG, C., KAMPF, J., VALERIUS, O., KAEVER, V. \& STULKE, J. 2015. An essential poison: synthesis and degradation of cyclic di-AMP in Bacillus subtilis. J Bacteriol, 197, 3265-74.

GUO, R., GU, J., ZONG, S., WU, M. \& YANG, M. 2018. Structure and mechanism of mitochondrial electron transport chain. Biomed J, 41, 9-20.

HAASE, I., MORTL, S., KOHLER, P., BACHER, A. \& FISCHER, M. 2003.

Biosynthesis of riboflavin in archaea. 6,7-dimethyl-8-ribityllumazine synthase of Methanococcus jannaschii. Eur J Biochem, 270, 1025-32.

HAASE, P., DEPPENMEIER, U., BLAUT, M. \& GOTTSCHALK, G. 1992. Purification and characterization of $\mathrm{F} 42 \mathrm{OH} 2$-dehydrogenase from Methanolobus tindarius. Eur J Biochem, 203, 527-31.

HAQUE, R. U., PARADISI, F. \& ALLERS, T. 2020. Haloferax volcanii for biotechnology applications: challenges, current state and perspectives. Appl Microbiol Biotechnol, 104, 1371-82.

HARTMAN, A. L., NORAIS, C., BADGER, J. H., DELMAS, S., HALDENBY, S., MADUPU, R., ROBINSON, J., KHOURI, H., REN, Q., LOWE, T. M., MAUPIN-FURLOW, J., POHLSCHRODER, M., DANIELS, C., PFEIFFER, F., ALLERS, T. \& EISEN, J. A. 2010. The complete genome sequence of Haloferax volcanii DS2, a model archaeon. PLoS One, 5, e9605. 
1149

HARTWELL, L. H. \& MAGASANIK, B. 1963. The molecular basis of histidase induction in Bacillus subtilis. J Mol Biol, 7, 401-20.

HATTORI, T., SHIBA, H., ASHIKI, K., ARAKI, T., NAGASHIMA, Y. K., YOSHIMATSU, K. \& FUJIWARA, T. 2016. Anaerobic growth of haloarchaeon Haloferax volcanii by denitrification is controlled by the transcription regulator NarO. J Bacteriol, 198, 1077-86.

HE, J., YIN, W., GALPERIN, M. Y. \& CHOU, S. H. 2020. Cyclic di-AMP, a second messenger of primary importance: tertiary structures and binding mechanisms. Nucleic Acids Res, 48, 2807-29.

HEATH, C., POSNER, M. G., AASS, H. C., UPADHYAY, A., SCOTT, D. J., HOUGH, D. W. \& DANSON, M. J. 2007. The 2-oxoacid dehydrogenase multi-enzyme complex of the archaeon Thermoplasma acidophilum - recombinant expression, assembly and characterization. FEBS J, 274, 5406-15.

HEYER, R., DORR, M., JELLEN-RITTER, A., SPATH, B., BABSKI, J., JASCHINSKI, K., SOPPA, J. \& MARCHFELDER, A. 2012. High throughput sequencing reveals a plethora of small RNAs including tRNA derived fragments in Haloferax volcanii. RNA biology, 9, 1011-8.

HILDEBRANDT, P., MATYSIK, J., SCHRADER, B., SCHARF, B. \& ENGELHARD, M. 1994. Raman spectroscopic study of the blue copper protein halocyanin from Natronobacterium pharaonis. Biochemistry, 33, 11426-31.

HO, Y. Y., HUANG, Y. H. \& HUANG, C. Y. 2013. Chemical rescue of the posttranslationally carboxylated lysine mutant of allantoinase and dihydroorotase by metal ions and short-chain carboxylic acids. Amino Acids, 44, 1181-91.

HOCHULI, M., PATZELT, H., OESTERHELT, D., WUTHRICH, K. \& SZYPERSKI, T. 1999. Amino acid biosynthesis in the halophilic archaeon Haloarcula hispanica. J Bacteriol, 181, 3226-37.

HORIE, A., TOMITA, T., SAIKI, A., KONO, H., TAKA, H., MINEKI, R., FUJIMURA, T., NISHIYAMA, C., KUZUYAMA, T. \& NISHIYAMA, M. 2009. Discovery of proteinaceous $\mathrm{N}$-modification in lysine biosynthesis of Thermus thermophilus. Nat Chem Biol, 5, 673-9.

HOWELL, D. M., HARICH, K., XU, H. M. \& WHITE, R. H. 1998. Alpha-keto acid chain elongation reactions involved in the biosynthesis of coenzyme $b$ (7mercaptoheptanoyl threonine phosphate) in methanogenic archaea. Biochemistry, 37, 10108-17.

HOWELL, D. M., XU, H. \& WHITE, R. H. 1999. (R)-citramalate synthase in methanogenic archaea. $J$ Bacteriol, 181, 331-3. 
1185

1186

1187

1188

1189

1190

1191

1192

1193

1194

1195

1196

1197

1198

1199

1200

1201

1202

1203

1204

1205

1206

1207

1208

1209

1210

1211

1212

1213

1214

1215

1216

1217

1218

1219

1220

HUANG, M., OPPERMANN-SANIO, F. B. \& STEINBUCHEL, A. 1999. Biochemical and molecular characterization of the Bacillus subtilis acetoin catabolic pathway. J Bacteriol, 181, 3837-41.

HUNTER, S., APWEILER, R., ATTWOOD, T. K., BAIROCH, A., BATEMAN, A., BINNS, D., BORK, P., DAS, U., DAUGHERTY, L., DUQUENNE, L., FINN, R. D., GOUGH, J., HAFT, D., HULO, N., KAHN, D., KELLY, E., LAUGRAUD, A., LETUNIC, I., LONSDALE, D., LOPEZ, R., MADERA, M., MASLEN, J., MCANULLA, C., MCDOWALL, J., MISTRY, J., MITCHELL, A., MULDER, N., NATALE, D., ORENGO, C., QUINN, A. F., SELENGUT, J. D., SIGRIST, C. J., THIMMA, M., THOMAS, P. D., VALENTIN, F., WILSON, D., WU, C. H. \& YEATS, C. 2009. InterPro: the integrative protein signature database. Nucleic Acids Res, 37, D211-5.

HWANG, S., CORDOVA, B., ABDO, M., PFEIFFER, F. \& MAUPIN-FURLOW, J. A. 2017. ThiN as a versatile domain of transcriptional repressors and catalytic enzymes of thiamine biosynthesis. J Bacteriol, 199, e00810-16.

ISHIKAWA, R., ISHIDO, Y., TACHIKAWA, A., KAWASAKI, H., MATSUZAWA, H. \& WAKAGI, T. 2002. Aeropyrum pernix K1, a strictly aerobic and hyperthermophilic archaeon, has two terminal oxidases, cytochrome ba3 and cytochrome aa3. Arch Microbiol, 179, 42-9.

ISSALY, I. M. \& ISSALY, A. S. 1974. Control of ornithine carbamoyltransferase activityby arginase in Bacillus subtilis. Eur J Biochem, 49, 485-95.

ISUPOV, M. N., BOYKO, K. M., SUTTER, J. M., JAMES, P., SAYER, C., SCHMIDT, M., SCHONHEIT, P., NIKOLAEVA, A. Y., STEKHANOVA, T. N., MARDANOV, A. V., RAVIN, N. V., BEZSUDNOVA, E. Y., POPOV, V. O. \& LITTLECHILD, J. A. 2019. Thermostable branched-chain amino acid transaminases from the archaea Geoglobus acetivorans and Archaeoglobus fulgidus: biochemical and structural characterization. Front Bioeng Biotechnol, $7,7$.

JAIN, S., CAFORIO, A., FODRAN, P., LOLKEMA, J. S., MINNAARD, A. J. \& DRIESSEN, A. J. M. 2014. Identification of CDP-archaeol synthase, a missing link of ether lipid biosynthesis in Archaea. Chem Biol, 21, 1392-401.

JENSEN, P. E., GIBSON, L. C., HENNINGSEN, K. W. \& HUNTER, C. N. 1996.

Expression of the chll, chID, and chlH genes from the Cyanobacterium Synechocystis PCC6803 in Escherichia coli and demonstration that the three cognate proteins are required for magnesium-protoporphyrin chelatase activity. J Biol Chem, 271, 16662-7. 
1221

1222

1223

1224

1225

1226

1228

1229

1230

1231

1232

1233

1234

1235

1236

1237

1238

1239

1240

1241

1242

1243

1244

1245

1246

1247

1248

1249

1250

1251

1252

1253

1254

1255

1256

JENSEN, P. E., GIBSON, L. C. \& HUNTER, C. N. 1998. Determinants of catalytic activity with the use of purified I, D and $\mathrm{H}$ subunits of the magnesium protoporphyrin IX chelatase from Synechocystis PCC6803. Biochem J, 334 ( Pt 2), 335-44.

JIANG, M., CHEN, M., GUO, Z. F. \& GUO, Z. 2010. A bicarbonate cofactor modulates 1,4-dihydroxy-2-naphthoyl-coenzyme a synthase in menaquinone biosynthesis of Escherichia coli. J Biol Chem, 285, 30159-69.

JOHNSEN, U., DAMBECK, M., ZAISS, H., FUHRER, T., SOPPA, J., SAUER, U. \& SCHONHEIT, P. 2009. D-xylose degradation pathway in the halophilic archaeon Haloferax volcanii. J Biol Chem, 284, 27290-303.

JOHNSEN, U., SUTTER, J. M., SCHULZ, A. C., TASTENSEN, J. B. \& SCHONHEIT, P. 2015. XacR - a novel transcriptional regulator of D-xylose and L-arabinose catabolism in the haloarchaeon Haloferax volcanii. Environ Microbiol, 17, 1663-76.

JOHNSON, C. L., PECHONICK, E., PARK, S. D., HAVEMANN, G. D., LEAL, N. A. \& BOBIK, T. A. 2001. Functional genomic, biochemical, and genetic characterization of the Salmonella pduO gene, an ATP:cob(I)alamin adenosyltransferase gene. J Bacteriol, 183, 1577-84.

JOHNSON, E. F. \& MUKHOPADHYAY, B. 2005. A new type of sulfite reductase, a novel coenzyme F420-dependent enzyme, from the methanarchaeon Methanocaldococcus jannaschii. J Biol Chem, 280, 38776-86.

JOHNSON, M., ZARETSKAYA, I., RAYTSELIS, Y., MEREZHUK, Y., MCGINNIS, S. \& MADDEN, T. L. 2008. NCBI BLAST: a better web interface. Nucleic Acids Res, 36, W5-9.

JOLLEY, K. A., MADDOCKS, D. G., GYLES, S. L., MULLAN, Z., TANG, S. L., DYALL-SMITH, M. L., HOUGH, D. W. \& DANSON, M. J. 2000. 2-Oxoacid dehydrogenase multienzyme complexes in the halophilic Archaea? Gene sequences and protein structural predictions. Microbiology (Reading), 146 ( Pt 5), 1061-69.

KAILA, V. R. I. \& WIKSTROM, M. 2021. Architecture of bacterial respiratory chains. Nat Rev Microbiol, 19, 319-30.

KAJIWARA, Y., SANTANDER, P. J., ROESSNER, C. A., PEREZ, L. M. \& SCOTT, A. I. 2006. Genetically engineered synthesis and structural characterization of cobalt-precorrin $5 \mathrm{~A}$ and $-5 \mathrm{~B}$, two new intermediates on the anaerobic pathway to vitamin B12: definition of the roles of the CbiF and CbiG enzymes. $J \mathrm{Am}$ Chem Soc, 128, 9971-8. 
KAMINSKAS, E., KIMHI, Y. \& MAGASANIK, B. 1970. Urocanase and N-formimino-Lglutamate formiminohydrolase of Bacillus subtilis, two enzymes of the histidine degradation pathway. J Biol Chem, 245, 3536-44.

KAMINSKI, L. \& EICHLER, J. 2014. Haloferax volcanii N-glycosylation: delineating the pathway of dTDP-rhamnose biosynthesis. PLoS One, 9, e97441.

KANDIBA, L., LIN, C. W., AEBI, M., EICHLER, J. \& GUERARDEL, Y. 2016. Structural characterization of the $\mathrm{N}$-linked pentasaccharide decorating glycoproteins of the halophilic archaeon Haloferax volcanii. Glycobiology, 26, 745-56.

KANEHISA, M., SATO, Y., FURUMICHI, M., MORISHIMA, K. \& TANABE, M. 2019. New approach for understanding genome variations in KEGG. Nucleic Acids Res, 47, D590-D95.

KANG, B. S. \& KIM, Y. M. 1999. Cloning and molecular characterization of the genes for carbon monoxide dehydrogenase and localization of molybdopterin, flavin adenine dinucleotide, and iron-sulfur centers in the enzyme of Hydrogenophaga pseudoflava. J Bacteriol, 181, 5581-90.

KARATZA, P. \& FRILLINGOS, S. 2005. Cloning and functional characterization of two bacterial members of the NAT/NCS2 family in Escherichia coli. Mol Membr Biol, 22, 251-61.

KARDINAHL, S., SCHMIDT, C. L., HANSEN, T., ANEMULLER, S., PETERSEN, A. \& SCHAFER, G. 1999. The strict molybdate-dependence of glucosedegradation by the thermoacidophile Sulfolobus acidocaldarius reveals the first crenarchaeotic molybdenum containing enzyme - an aldehyde oxidoreductase. European Journal of Biochemistry, 260, 540-48.

KATES, M. 1993. Biology of halophilic bacteria, Part II. Membrane lipids of extreme halophiles: biosynthesis, function and evolutionary significance. Experientia, 49, 1027-36.

KATES, M., MOLDOVEANU, N. \& STEWART, L. C. 1993. On the revised structure of the major phospholipid of Halobacterium salinarium. Biochim Biophys Acta, 1169, 46-53.

KATO, C., KURIHARA, T., KOBASHI, N., YAMANE, H. \& NISHIYAMA, M. 2004. Conversion of feedback regulation in aspartate kinase by domain exchange. Biochem Biophys Res Commun, 316, 802-8.

KAUR, N., GAUTAM, A., KUMAR, S., SINGH, A., SINGH, N., SHARMA, S., SHARMA, R., TEWARI, R. \& SINGH, T. P. 2011. Biochemical studies and crystal structure determination of dihydrodipicolinate synthase from Pseudomonas aeruginosa. Int J Biol Macromol, 48, 779-87. 
1294

KAWAI, S., MORI, S., MUKAI, T., SUZUKI, S., YAMADA, T., HASHIMOTO, W. \& MURATA, K. 2000. Inorganic Polyphosphate/ATP-NAD kinase of Micrococcus flavus and Mycobacterium tuberculosis H37Rv. Biochem Biophys Res Commun, 276, 57-63.

KEIGHTLEY, J. A., ZIMMERMANN, B. H., MATHER, M. W., SPRINGER, P., PASTUSZYN, A., LAWRENCE, D. M. \& FEE, J. A. 1995. Molecular genetic and protein chemical characterization of the cytochrome ba3 from Thermus thermophilus HB8. J Biol Chem, 270, 20345-58.

KELLERMANN, M. Y., YOSHINAGA, M. Y., VALENTINE, R. C., WORMER, L. \& VALENTINE, D. L. 2016. Important roles for membrane lipids in haloarchaeal bioenergetics. Biochim Biophys Acta, 1858, 2940-56.

KERSCHER, L. \& OESTERHELT, D. 1976. A ferredoxin from halobacteria. FEBS Letters, 67, 320-22.

KERSCHER, L. \& OESTERHELT, D. 1977. Ferredoxin is the coenzyme of $\alpha-$ ketoacid oxidoreductases in Halobacterium halobium. FEBS Letters, 83, 197201.

KERSCHER, L. \& OESTERHELT, D. 1981a. The catalytic mechanism of 2oxoacid:ferredoxin oxidoreductases from Halobacterium halobium. Oneelectron transfer at two distinct steps of the catalytic cycle. Eur J Biochem, $116,595-600$.

KERSCHER, L. \& OESTERHELT, D. 1981b. Purification and properties of two 2oxoacid:ferredoxin oxidoreductases from Halobacterium halobium. Eur $J$ Biochem, 116, 587-94.

KERSCHER, L., OESTERHELT, D., CAMMACK, R. \& HALL, D. O. 1976. A new plant-type ferredoxin from halobacteria. Eur J Biochem, 71, 101-7.

KILJUNEN, S., PAJUNEN, M. I., DILKS, K., STORF, S., POHLSCHRODER, M. \& SAVILAHTI, H. 2014. Generation of comprehensive transposon insertion mutant library for the model archaeon, Haloferax volcanii, and its use for gene discovery. BMC Biol, 12, 103.

KIM, K., PARK, J. \& RHEE, S. 2007. Structural and functional basis for (S)-allantoin formation in the ureide pathway. $J$ Biol Chem, 282, 23457-64.

KLEIN, A. R., BERK, H., PURWANTINI, E., DANIELS, L. \& THAUER, R. K. 1996. Siface stereospecificity at C5 of coenzyme F420 for F420-dependent glucose-6phosphate dehydrogenase from Mycobacterium smegmatis and F420dependent alcohol dehydrogenase from Methanoculleus thermophilicus. Eur J Biochem, 239, 93-7. 
1330

1331

1332

1333

1334

1335

1336

1337

1338

1339

1340

1341

1342

1343

1344

1346

1347

1348

1349

1350

1351

1352

1353

1354

1355

1356

1357

1358

1359

1360

1361

1362

1363

1364

1365

1366

KLEINE, T., LOCKHART, P. \& BATSCHAUER, A. 2003. An Arabidopsis protein closely related to Synechocystis cryptochrome is targeted to organelles. Plant $J, 35,93-103$.

KLETZIN, A., HEIMERL, T., FLECHSLER, J., VAN NIFTRIK, L., RACHEL, R. \& KLINGL, A. 2015. Cytochromes $\mathrm{C}$ in Archaea: distribution, maturation, cell architecture, and the special case of Ignicoccus hospitalis. Front Microbiol, 6, 439.

KOIKE-TAKESHITA, A., KOYAMA, T. \& OGURA, K. 1997. Identification of a novel gene cluster participating in menaquinone (vitamin K2) biosynthesis. Cloning and sequence determination of the 2-heptaprenyl-1,4-naphthoquinone methyltransferase gene of Bacillus stearothermophilus. J Biol Chem, 272, 12380-3.

KRIVENTSEVA, E. V., KUZNETSOV, D., TEGENFELDT, F., MANNI, M., DIAS, R., SIMAO, F. A. \& ZDOBNOV, E. M. 2019. OrthoDB v10: sampling the diversity of animal, plant, fungal, protist, bacterial and viral genomes for evolutionary and functional annotations of orthologs. Nucleic Acids Res, 47, D807-D11.

KUBATOVA, N., JONKER, H. R. A., SAXENA, K., RICHTER, C., VOGEL, V., SCHREIBER, S., MARCHFELDER, A. \& SCHWALBE, H. 2020. Solution Structure and Dynamics of the Small Protein HVO_2922 from Haloferax volcanii. Chembiochem, 21, 149-56.

KUHNER, M., HAUFSCHILDT, K., NEUMANN, A., STORBECK, S., STREIF, J. \& LAYER, G. 2014. The alternative route to heme in the methanogenic archaeon Methanosarcina barkeri. Archaea, 2014, Article ID 327637.

KUNOW, J., SCHWOËRER, B., STETTER, K. O. \& THAUER, R. K. 1993. A F420dependent NADP reductase in the extremely thermophilic sulfate-reducing Archaeoglobus fulgidus. Archives of Microbiology, 160, 199-205.

KUPRAT, T., JOHNSEN, U., ORTJOHANN, M. \& SCHONHEIT, P. 2020. Acetate metabolism in Archaea: characterization of an acetate transporter and of enzymes involved in acetate activation and gluconeogenesis in Haloferax volcanii. Front Microbiol, 11, 604926.

KUPRAT, T., ORTJOHANN, M., JOHNSEN, U. \& SCHONHEIT, P. 2021. Glucose metabolism and acetate switch in Archaea: the enzymes in Haloferax volcanii. J Bacteriol, 203, e00690-20.

KUSHWAHA, S. C., KRAMER, J. K. G. \& KATES, M. 1975. Isolation and characterization of $\mathrm{C} 50$-carotenoid pigments and other polar isoprenoids from Halobacterium cutirubrum. Biochimica et Biophysica Acta (BBA) - Lipids and Lipid Metabolism, 398, 303-14. 
1367

1368

1369

1370

1371

1372

1373

1374

1375

1376

1377

1378

1379

1380

1381

1382

1383

1384

1385

1386

1387

1388

1389

1390

1392

1393

1394

1395

1396

1397

1398

1399

1400

1401

1402

LARGE, A., STAMME, C., LANGE, C., DUAN, Z., ALLERS, T., SOPPA, J. \& LUND, P. A. 2007. Characterization of a tightly controlled promoter of the halophilic archaeon Haloferax volcanii and its use in the analysis of the essential cct1 gene. Mol Microbiol, 66, 1092-106.

LEE, T.-X., METZGER, S. U., CHO, Y. S., WHITMARSH, J. \& KALLAS, T. 2001. Modification of inhibitor binding sites in the cytochrome bf complex by directed mutagenesis of cytochrome b6 in Synechococcus sp. PCC 7002. Biochimica et Biophysica Acta (BBA) - Bioenergetics, 1504, 235-47.

LEE, Y., LEE, D. H., KHO, C. W., LEE, A. Y., JANG, M., CHO, S., LEE, C. H., LEE, J. S., MYUNG, P. K., PARK, B. C. \& PARK, S. G. 2005. Transthyretin-related proteins function to facilitate the hydrolysis of 5-hydroxyisourate, the end product of the uricase reaction. FEBS Lett, 579, 4769-74.

LEFFERS, H., GROPP, F., LOTTSPEICH, F., ZILLIG, W. \& GARRETT, R. A. 1989. Sequence, organization, transcription and evolution of RNA polymerase subunit genes from the archaebacterial extreme halophiles Halobacterium halobium and Halococcus morrhuae. J Mol Biol, 206, 1-17.

LEIF, H., SLED, V. D., OHNISHI, T., WEISS, H. \& FRIEDRICH, T. 1995. Isolation and characterization of the proton-translocating NADH: ubiquinone oxidoreductase from Escherichia coli. Eur J Biochem, 230, 538-48.

LEIGH, J. A., ALBERS, S. V., ATOMI, H. \& ALLERS, T. 2011. Model organisms for genetics in the domain Archaea: methanogens, halophiles, Thermococcales and Sulfolobales. FEMS Microbiol Rev, 35, 577-608.

LEMKE, C., YEUNG, M. \& HOWELL, P. L. 1999. Expression, purification, crystallization and preliminary X-ray analysis of Escherichia coli argininosuccinate synthetase. Acta Crystallogr D Biol Crystallogr, 55, 202830.

LI, H., GRAUPNER, M., XU, H. \& WHITE, R. H. 2003. CofE catalyzes the addition of two glutamates to F420-0 in F420 coenzyme biosynthesis in Methanococcus jannaschii. Biochemistry, 42, 9771-8.

LI, Z., RODRIGUEZ-FRANCO, M., ALBERS, S. V. \& QUAX, T. E. F. 2020. The switch complex ArICDE connects the chemotaxis system and the archaellum. Mol Microbiol, 114, 468-79.

LIAO, Y., ITHURBIDE, S., EVENHUIS, C., LOWE, J. \& DUGGIN, I. G. 2021. Cell division in the archaeon Haloferax volcanii relies on two FtsZ proteins with distinct functions in division ring assembly and constriction. Nat Microbiol, 6, 594-605. 
1403

1404

1405

1406

1407

1408

1409

1410

1411

1412

1413

1414

1415

1416

1417

1418

1419

1420

1421

1422

1423

1424

1425

1426

1427

1428

1429

1430

1431

1432

1433

1434

1438

LIN, X. L. \& WHITE, R. H. 1986. Occurrence of coenzyme F420 and its gammamonoglutamyl derivative in nonmethanogenic archaebacteria. J Bacteriol, 168, 444-8.

LIN, Y. K., MYHRMAN, R., SCHRAG, M. L. \& GELB, M. H. 1988. Bacterial Nsuccinyl-L-diaminopimelic acid desuccinylase. Purification, partial characterization, and substrate specificity. J Biol Chem, 263, 1622-7.

LIU, J., KRULWICH, T. A. \& HICKS, D. B. 2008. Purification of two putative type II NADH dehydrogenases with different substrate specificities from alkaliphilic Bacillus pseudofirmus OF4. Biochim Biophys Acta, 1777, 453-61.

LOC'H, J., BLAUD, M., RETY, S., LEBARON, S., DESCHAMPS, P., BAREILLE, J., JOMBART, J., ROBERT-PAGANIN, J., DELBOS, L., CHARDON, F., ZHANG, E., CHARENTON, C., TOLLERVEY, D. \& LEULLIOT, N. 2014. RNA mimicry by the fap7 adenylate kinase in ribosome biogenesis. PLoS Biol, 12, e1001860.

MADEN, B. E. 2000. Tetrahydrofolate and tetrahydromethanopterin compared: functionally distinct carriers in C1 metabolism. Biochem J, 350 Pt 3, 609-29.

MADON, J. \& ZILLIG, W. 1983. A form of the DNA-dependent RNA polymerase of Halobacterium halobium, containing an additional component, is able to transcribe native DNA. Eur J Biochem, 133, 471-4.

MAIER, L. K., STACHLER, A. E., BRENDEL, J., STOLL, B., FISCHER, S., HAAS, K. A., SCHWARZ, T. S., ALKHNBASHI, O. S., SHARMA, K., URLAUB, H., BACKOFEN, R., GOPHNA, U. \& MARCHFELDER, A. 2019. The nuts and bolts of the Haloferax CRISPR-Cas system I-B. RNA Biol, 16, 469-80.

MARTINEZ-RODRIGUEZ, S., GARCIA-PINO, A., LAS HERAS-VAZQUEZ, F. J., CLEMENTE-JIMENEZ, J. M., RODRIGUEZ-VICO, F., GARCIA-RUIZ, J. M., LORIS, R. \& GAVIRA, J. A. 2012. Mutational and structural analysis of L-Ncarbamoylase reveals new insights into a peptidase M20/M25/M40 family member. J Bacteriol, 194, 5759-68.

MASHHADI, Z., XU, H., GROCHOWSKI, L. L. \& WHITE, R. H. 2010. Archaeal RibL: a new FAD synthetase that is air sensitive. Biochemistry, 49, 8748-55.

MASHHADI, Z., XU, H. \& WHITE, R. H. 2009. An Fe ${ }^{2+}$-dependent cyclic phosphodiesterase catalyzes the hydrolysis of 7,8-dihydro-D-neopterin 2',3'cyclic phosphate in methanopterin biosynthesis. Biochemistry, 48, 9384-92.

MATTAR, S. 1996. Molekularbiologische und Biochemische Charakterisierung zweier Komplexe der Atmungskette von Natronobacterium pharaonis. Ph.D., Ruhr-Universität Bochum. 
1439

1440

1441

1442

1443

1444

1446

1447

1448

1449

1450

1451

1452

1453

1454

1455

1456

1457

1458

1459

1460

1461

1462

1463

1464

1465

1466

1467

1468

1469

1470

1471

1472

1473

MATTAR, S. \& ENGELHARD, M. 1997. Cytochrome ba3 from Natronobacterium pharaonis--an archaeal four-subunit cytochrome-c-type oxidase. Eur $J$ Biochem, 250, 332-41.

MATTAR, S., SCHARF, B., KENT, S. B., RODEWALD, K., OESTERHELT, D. \& ENGELHARD, M. 1994. The primary structure of halocyanin, an archaeal blue copper protein, predicts a lipid anchor for membrane fixation. Journal of Biological Chemistry, 269, 14939-45.

MAURER, S., LUDT, K. \& SOPPA, J. 2018. Characterization of copy number control of two Haloferax volcanii replication origins using deletion mutants and haloarchaeal artificial chromosomes. J Bacteriol, 200.

MCCREADY, S. \& MARCELLO, L. 2003. Repair of UV damage in Halobacterium salinarum. Biochem Soc Trans, 31, 694-8.

MILLER, M. J. \& GENNIS, R. B. 1983. The purification and characterization of the cytochrome d terminal oxidase complex of the Escherichia coli aerobic respiratory chain. J Biol Chem, 258, 9159-65.

MIYAZAKI, J., KOBASHI, N., NISHIYAMA, M. \& YAMANE, H. 2001. Functional and evolutionary relationship between arginine biosynthesis and prokaryotic lysine biosynthesis through alpha-aminoadipate. J Bacteriol, 183, 5067-73.

MOON, S., KIM, J., KOO, J. \& BAE, E. 2019. Structural and mutational analyses of psychrophilic and mesophilic adenylate kinases highlight the role of hydrophobic interactions in protein thermal stability. Struct Dyn, 6, 024702.

MOORE, S. J., LAWRENCE, A. D., BIEDENDIECK, R., DEERY, E., FRANK, S., HOWARD, M. J., RIGBY, S. E. \& WARREN, M. J. 2013. Elucidation of the anaerobic pathway for the corrin component of cobalamin (vitamin B12). Proc Natl Acad Sci U S A, 110, 14906-11.

MORII, H., KIYONARI, S., ISHINO, Y. \& KOGA, Y. 2009. A novel biosynthetic pathway of archaetidyl-myo-inositol via archaetidyl-myo-inositol phosphate from CDP-archaeol and D-glucose 6-phosphate in methanoarchaeon Methanothermobacter thermautotrophicus cells. J Biol Chem, 284, 30766-74.

MORII, H. \& KOGA, Y. 2003. CDP-2,3-Di-O-geranylgeranyl-sn-glycerol:L-serine Oarchaetidyltransferase (archaetidylserine synthase) in the methanogenic archaeon Methanothermobacter thermautotrophicus. J Bacteriol, 185, 1181-9.

MOSHIRI, F., CHAWLA, A. \& MAIER, R. J. 1991. Cloning, characterization, and expression in Escherichia coli of the genes encoding the cytochrome d oxidase complex from Azotobacter vinelandii. J Bacteriol, 173, 6230-41. 
1474

1475

1476

1477

1478

1479

1480

1481

1482

1483

1484

1485

1486

1487

1488

1489

1490

1491

1492

1493

1494

1495

1496

1498

1499

1500

1501

1502

1503

1504

1505

1506

1507

1508

1509

NAGEL, C., MACHULLA, A., ZAHN, S. \& SOPPA, J. 2019. Several one-domain zinc finger micro-proteins of Haloferax volcanii are important for stress adaptation, biofilm formation, and swarming. Genes (Basel), 10, 361.

NAM, S. E., KIM, A. C. \& PAETZEL, M. 2012. Crystal structure of Bacillus subtilis signal peptide peptidase A. J Mol Biol, 419, 347-58.

NANBA, T. \& MUKOHATA, Y. 1987. A membrane-bound ATPase from Halobacterium halobium: purification and characterization. J Biochem (Tokyo), 102, 591-8.

NEELON, K., ROBERTS, M. F. \& STEC, B. 2011. Crystal structure of a trapped catalytic intermediate suggests that forced atomic proximity drives the catalysis of mIPS. Biophys J, 101, 2816-24.

NEWTON, W. A., MORINO, Y. \& SNELL, E. E. 1965. Properties of crystalline tryptophanase. J Biol Chem, 240, 1211-8.

NG, S. Y., CHABAN, B., VANDYKE, D. J. \& JARRELL, K. F. 2007. Archaeal signal peptidases. Microbiology (Reading), 153, 305-14.

NOCEK, B., EVDOKIMOVA, E., PROUDFOOT, M., KUDRITSKA, M., GROCHOWSKI, L. L., WHITE, R. H., SAVCHENKO, A., YAKUNIN, A. F., EDWARDS, A. \& JOACHIMIAK, A. 2007. Structure of an amide bond forming F(420):gamma-glutamyl ligase from Archaeoglobus fulgidus -- a member of a new family of non-ribosomal peptide synthases. J Mol Biol, 372, 456-69.

NUSSBAUM, P., ITHURBIDE, S., WALSH, J. C., PATRO, M., DELPECH, F., RODRIGUEZ-FRANCO, M., CURMI, P. M. G., DUGGIN, I. G., QUAX, T. E. F. \& ALBERS, S. V. 2020. An oscillating MinD protein determines the cellular positioning of the motility machinery in Archaea. Curr Biol, 30, 4956-72 e4.

O'TOOLE, G. A., TRZEBIATOWSKI, J. R. \& ESCALANTE-SEMERENA, J. C. 1994. The cobC gene of Salmonella typhimurium codes for a novel phosphatase involved in the assembly of the nucleotide loop of cobalamin. Journal of Biological Chemistry, 269, 26503-11.

OBERTO, J. 2013. SyntTax: a web server linking synteny to prokaryotic taxonomy. BMC Bioinformatics, 14, 4.

ODA, M., SUGISHITA, A. \& FURUKAWA, K. 1988. Cloning and nucleotide sequences of histidase and regulatory genes in the Bacillus subtilis hut operon and positive regulation of the operon. J Bacteriol, 170, 3199-205.

OHNISHI, H., KITAMURA, H., MINOWA, T., SAKAI, H. \& OHTA, T. 1992. Molecular cloning of a glucoamylase gene from a thermophilic Clostridium and kinetics of the cloned enzyme. Eur J Biochem, 207, 413-8. 
1510

1511

1512

1513

1514

1515

1516

1517

1518

1519

1520

1521

1522

1523

1524

1525

1526

1527

1528

1530

1531

1532

1533

1534

1535

1536

1537

1538

1539

1540

1541

1542

1543

1544

1545

1546

OPPERMANN, F. B., SCHMIDT, B. \& STEINBUCHEL, A. 1991. Purification and characterization of acetoin:2,6-dichlorophenolindophenol oxidoreductase, dihydrolipoamide dehydrogenase, and dihydrolipoamide acetyltransferase of the Pelobacter carbinolicus acetoin dehydrogenase enzyme system. $J$ Bacteriol, 173, 757-67.

OREN, A. 2002. Molecular ecology of extremely halophilic Archaea and Bacteria. FEMS Microbiol. Ecol., 39, 1-7.

OREN, A., VENTOSA, A. \& GRANT, W. D. 1997. Proposed minimal standards for description of new taxa in the order Halobacteriales. International Journal of Systematic Bacteriology, 47, 233-38.

OTAKA, E., HIGO, K. \& ITOH, T. 1984. Yeast ribosomal proteins. VIII. Isolation of two proteins and sequence characterization of twenty-four proteins from cytoplasmic ribosomes. Mol Gen Genet, 195, 544-6.

OUCHI, T., TOMITA, T., HORIE, A., YOSHIDA, A., TAKAHASHI, K., NISHIDA, H., LASSAK, K., TAKA, H., MINEKI, R., FUJIMURA, T., KOSONO, S., NISHIYAMA, C., MASUI, R., KURAMITSU, S., ALBERS, S. V., KUZUYAMA, T. \& NISHIYAMA, M. 2013. Lysine and arginine biosyntheses mediated by a common carrier protein in Sulfolobus. Nat Chem Biol, 9, 277-83.

PALMER, D. R., GARRETT, J. B., SHARMA, V., MEGANATHAN, R., BABBITT, P. C. \& GERLT, J. A. 1999. Unexpected divergence of enzyme function and sequence: " $\mathrm{N}$-acylamino acid racemase" is o-succinylbenzoate synthase. Biochemistry, 38, 4252-8.

PAN, X., CAO, D., XIE, F., XU, F., SU, X., MI, H., ZHANG, X. \& LI, M. 2020. Structural basis for electron transport mechanism of complex I-like photosynthetic $\mathrm{NAD}(\mathrm{P}) \mathrm{H}$ dehydrogenase. Nat Commun, 11, 610.

PENNINGTON, J. M., KEMP, M., MCGARRY, L., CHEN, Y. \& STROUPE, M. E. 2020. Siroheme synthase orients substrates for dehydrogenase and chelatase activities in a common active site. Nat Commun, 11, 864.

PEREZ-ARNAIZ, P., DATTANI, A., SMITH, V. \& ALLERS, T. 2020. Haloferax volcanii-a model archaeon for studying DNA replication and repair. Open Biol, 10, 200293.

PETROVA, T. E., BOYKO, K. M., NIKOLAEVA, A. Y., STEKHANOVA, T. N., GRUZDEV, E. V., MARDANOV, A. V., STROILOV, V. S., LITTLECHILD, J. A., POPOV, V. O. \& BEZSUDNOVA, E. Y. 2018. Structural characterization of geranylgeranyl pyrophosphate synthase GACE1337 from the hyperthermophilic archaeon Geoglobus acetivorans. Extremophiles, 22, 877 88. 
PFEIFFER, F., BROICHER, A., GILLICH, T., KLEE, K., MEJIA, J., RAMPP, M. \& OESTERHELT, D. 2008a. Genome information management and integrated data analysis with HaloLex. Arch Microbiol, 190, 281-99.

PFEIFFER, F., LOSENSKY, G., MARCHFELDER, A., HABERMANN, B. \& DYALLSMITH, M. 2020. Whole-genome comparison between the type strain of Halobacterium salinarum (DSM 3754(T) ) and the laboratory strains R1 and NRC-1. Microbiologyopen, 9, e974.

PFEIFFER, F. \& OESTERHELT, D. 2015. A manual curation strategy to improve genome annotation: application to a set of haloarchael genomes. Life (Basel), $5,1427-44$.

PFEIFFER, F., SCHUSTER, S. C., BROICHER, A., FALB, M., PALM, P., RODEWALD, K., RUEPP, A., SOPPA, J., TITTOR, J. \& OESTERHELT, D. 2008b. Evolution in the laboratory: the genome of Halobacterium salinarum strain R1 compared to that of strain NRC-1. Genomics, 91, 335-46.

PFRIMER, P., DE MORAES, L. M., GALDINO, A. S., SALLES, L. P., REIS, V. C., DE MARCO, J. L., PRATES, M. V., BLOCH, C., JR. \& TORRES, F. A. 2010. Cloning, purification, and partial characterization of Bacillus subtilis urate oxidase expressed in Escherichia coli. J Biomed Biotechnol, 2010, 674908. PHILLIPS, G., GROCHOWSKI, L. L., BONNETT, S., XU, H., BAILLY, M., BLABYHAAS, C., EL YACOUBI, B., IWATA-REUYL, D., WHITE, R. H. \& DE CRECY-LAGARD, V. 2012. Functional promiscuity of the COG0720 family. ACS Chem Biol, 7, 197-209.

PHILLIPS, R. S. \& GOLLNICK, P. D. 1989. Evidence that cysteine 298 Is in the active site of tryptophan indole-lyase. Journal of Biological Chemistry, 264, 10627-32.

PHILMUS, B., DECAMPS, L., BERTEAU, O. \& BEGLEY, T. P. 2015. Biosynthetic versatility and coordinated action of 5'-deoxyadenosyl radicals in deazaflavin biosynthesis. J Am Chem Soc, 137, 5406-13.

PICKL, A., JOHNSEN, U. \& SCHONHEIT, P. 2012. Fructose degradation in the haloarchaeon Haloferax volcanii involves a bacterial type phosphoenolpyruvate-dependent phosphotransferase system, fructose-1phosphate kinase, and class II fructose-1,6-bisphosphate aldolase. Journal of bacteriology, 194, 3088-97.

PLAGA, W., LOTTSPEICH, F. \& OESTERHELT, D. 1992. Improved purification, crystallization and primary structure of pyruvate:ferredoxin oxidoreductase from Halobacterium halobium. Eur J Biochem, 205, 391-7. 
1583

1584

1585

1586

1587

1588

1589

1590

1591

1592

1593

1594

1595

1596

1597

1598

1599

1600

1601

1602

1603

1604

1605

1606

1607

1608

1609

1610

1611

1612

1613

1614

1615

1616

1617

1618

POHLSCHRODER, M. \& ESQUIVEL, R. N. 2015. Archaeal type IV pili and their involvement in biofilm formation. Front Microbiol, 6, 190.

PORAT, I., SIEPRAWSKA-LUPA, M., TENG, Q., BOHANON, F. J., WHITE, R. H. \& WHITMAN, W. B. 2006. Biochemical and genetic characterization of an early step in a novel pathway for the biosynthesis of aromatic amino acids and $p$ aminobenzoic acid in the archaeon Methanococcus maripaludis. Mol Microbiol, 62, 1117-31.

PORAT, I., WATERS, B. W., TENG, Q. \& WHITMAN, W. B. 2004. Two biosynthetic pathways for aromatic amino acids in the archaeon Methanococcus maripaludis. J Bacteriol, 186, 4940-50.

PROMPONAS, V. J., ILIOPOULOS, I. \& OUZOUNIS, C. A. 2015. Annotation inconsistencies beyond sequence similarity-based function prediction phylogeny and genome structure. Stand Genomic Sci, 10, 108.

PRUNETTI, L., REUTER, C. J., HEPOWIT, N. L., WU, Y., BARRUETO, L., MIRANDA, H. V., KELLY, K. \& MAUPIN-FURLOW, J. A. 2014. Structural and biochemical properties of an extreme 'salt-loving' proteasome activating nucleotidase from the archaeon Haloferax volcanii. Extremophiles, 18, 28393.

PURWANTINI, E. \& MUKHOPADHYAY, B. 2013. Rv0132c of Mycobacterium tuberculosis encodes a coenzyme F420-dependent hydroxymycolic acid dehydrogenase. PLoS One, 8, e81985.

QI, Q., ITO, Y., YOSHIMATSU, K. \& FUJIWARA, T. 2016. Transcriptional regulation of dimethyl sulfoxide respiration in a haloarchaeon, Haloferax volcanii. Extremophiles, 20, 27-36.

QU, Q., LEE, S. J. \& BOOS, W. 2004. Molecular and biochemical characterization of a fructose-6-phosphate-forming and ATP-dependent fructokinase of the hyperthermophilic archaeon Thermococcus litoralis. Extremophiles, 8, 301-8.

QUAX, T. E. F., ALTEGOER, F., ROSSI, F., LI, Z., RODRIGUEZ-FRANCO, M., KRAUS, F., BANGE, G. \& ALBERS, S. V. 2018. Structure and function of the archaeal response regulator CheY. Proc Natl Acad Sci U S A, 115, E1259E68.

RAFFAELLI, N., EMANUELLI, M., PISANI, F. M., AMICI, A., LORENZI, T., RUGGIERI, S. \& MAGNI, G. 1999. Identification of the archaeal NMN adenylyltransferase gene. Molecular \& Cellular Biochemistry, 193, 99-102.

RAFFAELLI, N., PISANI, F. M., LORENZI, T., EMANUELLI, M., AMICI, A., RUGGIERI, S. \& MAGNI, G. 1997. Characterization of nicotinamide 
1619 mononucleotide adenylyltransferase from thermophilic archaea. J Bacteriol, 179, 7718-23.

RANGASWAMY, V. \& ALTEKAR, W. 1994. Ketohexokinase (ATP:D-fructose 1phosphotransferase) from a halophilic archaebacterium, Haloarcula vallismortis: purification and properties. J Bacteriol, 176, 5505-12.

RAUT, P., GLASS, J. B. \& LIEBERMAN, R. L. 2021. Archaeal roots of intramembrane aspartyl protease siblings signal peptide peptidase and presenilin. Proteins, 89, 232-41.

RAUX, E., LEECH, H. K., BECK, R., SCHUBERT, H. L., SANTANDER, P. J., ROESSNER, C. A., SCOTT, A. I., MARTENS, J. H., JAHN, D., THERMES, C., RAMBACH, A. \& WARREN, M. J. 2003. Identification and functional analysis of enzymes required for precorrin-2 dehydrogenation and metal ion insertion in the biosynthesis of sirohaem and cobalamin in Bacillus megaterium. Biochem J, 370, 505-16.

RAWLS, K. S., YACOVONE, S. K. \& MAUPIN-FURLOW, J. A. 2010. GlpR represses fructose and glucose metabolic enzymes at the level of transcription in the haloarchaeon Haloferax volcanii. J Bacteriol, 192, 6251-60.

REDDY, S. G., SACCHETTINI, J. C. \& BLANCHARD, J. S. 1995. Expression, purification, and characterization of Escherichia coli dihydrodipicolinate reductase. Biochemistry, 34, 3492-501.

REINHARDT, A., JOHNSEN, U. \& SCHONHEIT, P. 2019. L-Rhamnose catabolism in archaea. Mol Microbiol, 111, 1093-108.

REN, H., WANG, L., BENNETT, M., LIANG, Y., ZHENG, X., LU, F., LI, L., NAN, J., LUO, M., ERIKSSON, S., ZHANG, C. \& SU, X. D. 2005. The crystal structure of human adenylate kinase 6 : An adenylate kinase localized to the cell nucleus. Proc Natl Acad Sci U S A, 102, 303-8.

REUTER, C. J. \& MAUPIN-FURLOW, J. A. 2004. Analysis of proteasome-dependent proteolysis in Haloferax volcanii cells, using short-lived green fluorescent proteins. Appl. Environ. Microbiol., 70, 7530-38.

REUTER, C. J., UTHANDI, S., PUENTES, J. A. \& MAUPIN-FURLOW, J. A. 2010. Hydrophobic carboxy-terminal residues dramatically reduce protein levels in the haloarchaeon Haloferax volcanii. Microbiology (Reading), 156, 248-55.

RICH, P. R. \& MARECHAL, A. 2010. The mitochondrial respiratory chain. Essays Biochem, 47, 1-23.

RIVLIN, A. A., CHAN, Y. L. \& WOOL, I. G. 1999. The contribution of a zinc finger motif to the function of yeast ribosomal protein YL37a. J Mol Biol, 294, 90919. 
1656

1657

1658

1659

1660

1661

1662

1663

1664

1665

1666

1667

1668

1669

1670

1671

1672

1673

1674

1675

1676

1677

1678

1679

1680

1681

1682

1683

1684

1685

1686

1687

1688

1689

1690

1691

RODIONOV, D. A., VITRESCHAK, A. G., MIRONOV, A. A. \& GELFAND, M. S. 2003. Comparative genomics of the vitamin B12 metabolism and regulation in prokaryotes. J Biol Chem, 278, 41148-59.

RODiONOVA, I. A., VETTING, M. W., LI, X., ALMO, S. C., OSTERMAN, A. L. \& RODIONOV, D. A. 2017. A novel bifunctional transcriptional regulator of riboflavin metabolism in Archaea. Nucleic Acids Res, 45, 3785-99.

ROESSNER, C. A., WARREN, M. J., SANTANDER, P. J., ATSHAVES, B. P., OZAKI, S.-I., STOLOWICH, N. J., IIDA, K. \& SCOTT, A. I. 1992. Expression of 9 Salmonella typhimurium enzymes for cobinamide synthesis. Identification of the 11-methyl and 20-methyl transferases of corrin biosynthesis. FEBS Letters, 301, 73-78.

ROMISCH-MARGL, W., EISENREICH, W., HAASE, I., BACHER, A. \& FISCHER, M. 2008. 2,5-diamino-6-ribitylamino-4(3H)-pyrimidinone 5'-phosphate synthases of fungi and archaea. FEBS J, 275, 4403-14.

RUDOLPH, B., HANSEN, T. \& SCHONHEIT, P. 2004. Glucose-6-phosphate isomerase from the hyperthermophilic archaeon Methanococcus jannaschii: characterization of the first archaeal member of the phosphoglucose isomerase superfamily. Arch Microbiol, 181, 82-7.

RUEPP, A., MULLER, H. N., LOTTSPEICH, F. \& SOPPA, J. 1995. Catabolic ornithine transcarbamylase of halobacterium halobium (salinarium) purification, characterization, sequence determination, and evolution. Journal of Bacteriology, 177, 1129-36.

SANTANDER, P. J., KAJIWARA, Y., WILLIAMS, H. J. \& SCOTT, A. I. 2006. Structural characterization of novel cobalt corrinoids synthesized by enzymes of the vitamin B12 anaerobic pathway. Bioorg Med Chem, 14, 724-31.

SANTANDER, P. J., ROESSNER, C. A., STOLOWICH, N. J., HOLDERMAN, M. T. \& SCOTT, A. I. 1997. How corrinoids are synthesized without oxygen: nature's first pathway to vitamin B12. Chemistry \& Biology, 4, 659-66.

SATO, S., NAKADA, Y., KANAYA, S. \& TANAKA, T. 1988. Molecular cloning and nucleotide sequence of Thermus thermophilus HB8 trpE and trpG. Biochimica et Biophysica Acta (BBA) - Gene Structure and Expression, 950, 303-12.

SCHADT, H. S., SCHADT, S., OLDACH, F. \& SUSSMUTH, R. D. 2009. 2-Amino-2deoxyisochorismate is a key intermediate in Bacillus subtilis p-aminobenzoic acid biosynthesis. J Am Chem Soc, 131, 3481-3.

SCHAFER, G., ENGELHARD, M. \& MULLER, V. 1999. Bioenergetics of the Archaea. Microbiol Mol Biol Rev, 63, 570-620. 
1692

1693

1694

1695

1696

1697

1698

1699

1700

1701

1702

1703

1704

1705

1706

1707

1708

1709

1710

1711

1712

1713

1714

1715

1716

1717

1718

1719

1720

1721

1722

1723

1724

1725

1726

1727

SCHARF, B. \& ENGELHARD, M. 1993. Halocyanin, an archaebacterial blue copper protein (type I) from Natronobacterium pharaonis. Biochemistry, 32, 12894900.

SCHARF, B., WITTENBERG, R. \& ENGELHARD, M. 1997. Electron transfer proteins from the haloalkaliphilic archaeon Natronobacterium pharaonis: possible components of the respiratory chain include cytochrome bc and a terminal oxidase cytochrome ba3. Biochemistry, 36, 4471-9.

SCHILLER, H., SCHULZE, S., MUTAN, Z., DE VAULX, C., RUNCIE, C., SCHWARTZ, J., RADOS, T., BISSON FILHO, A. W. \& POHLSCHRODER, M. 2020. Haloferax volcanii immersed liquid biofilms develop independently of known biofilm machineries and exhibit rapid honeycomb pattern formation. mSphere, 5, e00976-20.

SCHMIDT, D. M., HUBBARD, B. K. \& GERLT, J. A. 2001. Evolution of enzymatic activities in the enolase superfamily: functional assignment of unknown proteins in Bacillus subtilis and Escherichia coli as L-Ala-D/L-Glu epimerases. Biochemistry, 40, 15707-15.

SCHNOES, A. M., BROWN, S. D., DODEVSKI, I. \& BABBITT, P. C. 2009. Annotation error in public databases: misannotation of molecular function in enzyme superfamilies. PLoS Comput Biol, 5, e1000605.

SCHOLZEN, T. \& ARNDT, E. 1991. Organization and nucleotide sequence of ten ribosomal protein genes from the region equivalent to the spectinomycin operon in the archaebacterium Halobacterium marismortui. Mol Gen Genet, 228, 70-80.

SCHUBERT, H. L., ROSE, R. S., LEECH, H. K., BRINDLEY, A. A., HILL, C. P., RIGBY, S. E. \& WARREN, M. J. 2008. Structure and function of SirC from Bacillus megaterium: a metal-binding precorrin-2 dehydrogenase. Biochem $\mathrm{J}$, 415, 257-63.

SCHULLER, J. M., BIRRELL, J. A., TANAKA, H., KONUMA, T., WULFHORST, H., COX, N., SCHULLER, S. K., THIEMANN, J., LUBITZ, W., SETIF, P., IKEGAMI, T., ENGEL, B. D., KURISU, G. \& NOWACZYK, M. M. 2019. Structural adaptations of photosynthetic complex I enable ferredoxindependent electron transfer. Science, 363, 257-60.

SCHULTZ, A. C., NYGAARD, P. \& SAXILD, H. H. 2001. Functional analysis of 14 genes that constitute the purine catabolic pathway in Bacillus subtilis and evidence for a novel regulon controlled by the PucR transcription activator. $J$ Bacteriol, 183, 3293-302. 
1728

1729

1730

1731

1732

1733

1734

1735

1736

1737

1738

1739

1740

1741

1742

1743

1744

1745

1746

1747

1748

1749

1750

1751

1752

1753

1754

1755

1756

1757

1758

1759

1760

1761

1762

1763

1764

SCHULZE, S., ADAMS, Z., CERLETTI, M., DE CASTRO, R., FERREIRA-CERCA, S., FUFEZAN, C., GIMENEZ, M. I., HIPPLER, M., JEVTIC, Z., KNUPPEL, R., LEGERME, G., LENZ, C., MARCHFELDER, A., MAUPIN-FURLOW, J., PAGGI, R. A., PFEIFFER, F., POETSCH, A., URLAUB, H. \& POHLSCHRODER, M. 2020. The Archaeal Proteome Project advances knowledge about archaeal cell biology through comprehensive proteomics. Nat Commun, 11, 3145.

SCHULZE, S., PFEIFFER, F., GARCIA, B. A. \& POHLSCHRODER, M. 2021. Glycoproteomics of Haloferax volcanii reveals an extensive glycoproteome and concurrence of different $\mathrm{N}$-glycosylation pathways. Available: https://www.biorxiv.org/content/biorxiv/early/2021/01/21/2021.01.21.427637.f ull.pdf [Accessed January 21, 2021].

SCOTT, J. W. \& RASCHE, M. E. 2002. Purification, overproduction, and partial characterization of beta-RFAP synthase, a key enzyme in the methanopterin biosynthesis pathway. J Bacteriol, 184, 4442-8.

SELBY, C. P. \& SANCAR, A. 2006. A cryptochrome/photolyase class of enzymes with single-stranded DNA-specific photolyase activity. Proc Natl Acad Sci U S A, 103, 17696-700.

SELENGUT, J. D. \& HAFT, D. H. 2010. Unexpected abundance of coenzyme F(420)-dependent enzymes in Mycobacterium tuberculosis and other actinobacteria. J Bacteriol, 192, 5788-98.

SERINO, L., REIMMANN, C., BAUR, H., BEYELER, M., VISCA, P. \& HAAS, D. 1995. Structural genes for salicylate biosynthesis from chorismate in Pseudomonas aeruginosa. Mol Gen Genet, 249, 217-28.

SHAHEEN, N., KOBAYASHI, K., TERAZONO, H., FUKUSHIGE, T., HORIUCHI, M. \& SAHEKI, T. 1994. Characterization of human wild-type and mutant argininosuccinate synthetase proteins expressed in bacterial cells. Enzyme Protein, 48, 251-64.

SHALEV, Y., SOUCY, S. M., PAPKE, R. T., GOGARTEN, J. P., EICHLER, J. \& GOPHNA, U. 2018. Comparative analysis of surface layer glycoproteins and genes involved in protein glycosylation in the genus Haloferax. Genes (Basel), 9, 172.

SHALEV, Y., TURGEMAN-GROTT, I., TAMIR, A., EICHLER, J. \& GOPHNA, U. 2017. Cell surface glycosylation is required for efficient mating of Haloferax volcanii. Front Microbiol, 8, 1253.

SHIMA, S., WARKENTIN, E., GRABARSE, W., SORDEL, M., WICKE, M., THAUER, R. K. \& ERMLER, U. 2000. Structure of coenzyme F(420) dependent 
1765

1766

1767

1768

1769

1770

1771

1772

1773

1774

1775

1776

1777

1778

1779

1780

1781

1782

1783

1784

1785

1786

1787

1788

1789

1790

1791

1792

1793

1794

1795

1796

1797

1798

1799

1800

methylenetetrahydromethanopterin reductase from two methanogenic archaea. J Mol Biol, 300, 935-50.

SHIMIZU, T., TOMITA, T., KUZUYAMA, T. \& NISHIYAMA, M. 2016. Crystal structure of the LysY.LysW complex from Thermus thermophilus. J Biol Chem, 291, 9948-59.

SIDDARAMAPPA, S., CHALLACOMBE, J. F., DECASTRO, R. E., PFEIFFER, F., SASTRE, D. E., GIMENEZ, M. I., PAGGI, R. A., DETTER, J. C., DAVENPORT, K. W., GOODWIN, L. A., KYRPIDES, N., TAPIA, R., PITLUCK, S., LUCAS, S., WOYKE, T. \& MAUPIN-FURLOW, J. A. 2012. A comparative genomics perspective on the genetic content of the alkaliphilic haloarchaeon Natrialba magadii ATCC 43099'. BMC Genomics, 13, 165.

SIMMS, S. A., VOIGE, W. H. \& GILVARG, C. 1984. Purification and characterization of succinyl-CoA: tetrahydrodipicolinate $\mathrm{N}$-succinyltransferase from Escherichia coli. J Biol Chem, 259, 2734-41.

SISIGNANO, M., MORBITZER, D., GATGENS, J., OLDIGES, M. \& SOPPA, J. 2010. A 2-oxoacid dehydrogenase complex of Haloferax volcanii is essential for growth on isoleucine but not on other branched-chain amino acids. Microbiology, 156, 521-9.

SLOCK, J., STAHLY, D. P., HAN, C. Y., SIX, E. W. \& CRAWFORD, I. P. 1990. An apparent Bacillus subtilis folic acid biosynthetic operon containing pab, an amphibolic trpG gene, a third gene required for synthesis of paraaminobenzoic acid, and the dihydropteroate synthase gene. J Bacteriol, 172, 7211-26.

SOPPA, J. 2011. Functional genomic and advanced genetic studies reveal novel insights into the metabolism, regulation, and biology of Haloferax volcanii. Archaea, 2011, 602408.

SPATH, B., SCHUBERT, S., LIEBEROTH, A., SETTELE, F., SCHUTZ, S., FISCHER, S. \& MARCHFELDER, A. 2008. Two archaeal tRNase Z enzymes: similar but different. Arch Microbiol, 190, 301-8.

SREERAMULU, K. 2003. Purification and partial characterization of cytochrome c552 from Halobacterium salinarium. Indian Journal of Biochemistry and Biophysics, 40, 274-77.

SREERAMULU, K., SCHMIDT, C. L., SCHAFER, G. \& ANEMULLER, S. 1998. Studies of the electron transport chain of the euryarcheon Halobacterium salinarum: indications for a type II NADH dehydrogenase and a complex III analog. J Bioenerg Biomembr, 30, 443-53. 
1801

1802

1803

1804

1805

1806

1807

1808

1809

1810

1811

1812

1813

1814

1815

1816

1817

1818

1819

1820

1821

1822

1823

1824

1825

1826

1827

1828

1829

1830

1831

1832

1833

1834

1835

1836

1837

STEINERT, K., WAGNER, V., KROTH PANCIC, P. G. \& BICKEL SANDKOETTER, S. 1997. Characterization and subunit structure of the ATP synthase of the halophilic archaeon Haloferax volcanii and organization of the ATP synthase genes. Journal of Biological Chemistry, 272, 6261-69.

STORBECK, S., ROLFES, S., RAUX-DEERY, E., WARREN, M. J., JAHN, D. \& LAYER, G. 2010. A novel pathway for the biosynthesis of heme in Archaea: genome-based bioinformatic predictions and experimental evidence. Archaea, 2010, 175050.

STORF, S., PFEIFFER, F., DILKS, K., CHEN, Z. Q., IMAM, S. \& POHLSCHRODER, M. 2010. Mutational and bioinformatic analysis of haloarchaeal lipoboxcontaining proteins. Archaea, 2010, Article ID 410975.

STRAUB, J., BRENNEIS, M., JELLEN-RITTER, A., HEYER, R., SOPPA, J. \& MARCHFELDER, A. 2009. Small RNAs in haloarchaea: Identification, differential expression and biological function. RNA Biol, 6.

STROUPE, M. E., LEECH, H. K., DANIELS, D. S., WARREN, M. J. \& GETZOFF, E. D. 2003. CysG structure reveals tetrapyrrole-binding features and novel regulation of siroheme biosynthesis. Nat Struct Biol, 10, 1064-73.

SU, X., LIN, Z., CHEN, W., JIANG, H., ZHANG, S. \& LIN, H. 2012. Chemogenomic approach identified yeast YLR143W as diphthamide synthetase. Proc Natl Acad Sci U S A, 109, 19983-7.

SUTTER, J. M., JOHNSEN, U., REINHARDT, A. \& SCHONHEIT, P. 2020. Pentose degradation in archaea: Halorhabdus species degrade D-xylose, L-arabinose and D-ribose via bacterial-type pathways. Extremophiles, 24, 759-72.

SUTTER, J. M., TASTENSEN, J. B., JOHNSEN, U., SOPPA, J. \& SCHONHEIT, P. 2016. Key enzymes of the semiphosphorylative Entner-Doudoroff pathway in the haloarchaeon Haloferax volcanii: Characterization of glucose dehydrogenase, gluconate dehydratase and 2-keto-3-deoxy-6phosphogluconate aldolase. J Bacteriol, 198, 2251-62.

SUVARNA, K., STEVENSON, D., MEGANATHAN, R. \& HUDSPETH, M. E. 1998. Menaquinone (vitamin K2) biosynthesis: localization and characterization of the menA gene from Escherichia coli. J Bacteriol, 180, 2782-7.

TACHIBANA, A. 1994. A novel prenyltransferase, farnesylgeranyl diphosphate synthase, from the haloalkaliphilic archaeon, Natronobacterium pharaonis. FEBS Letters, 341, 291-94.

TACHIBANA, A., YANO, Y., OTANI, S., NOMURA, N., SAKO, Y. \& TANIGUCHI, M. 2000. Novel prenyltransferase gene encoding farnesylgeranyl diphosphate synthase from a hyperthermophilic archaeon, Aeropyrum pernix - Molecular 
1838

1839

1840

1841

1842

1843

1844

1845

1846

1847

1848

1849

1850

1851

1852

1853

1854

1855

1856

1857

1858

1859

1860

1861

1862

1863

1864

1865

1866

1867

1868

1869

1870

1871

1872

1873

1874

evolution with alteration in product specificity. European Journal of Biochemistry, 267, 321-28.

TAKAO, M., KOBAYASHI, T., OIKAWA, A. \& YASUI, A. 1989. Tandem arrangement of photolyase and superoxide dismutase genes in Halobacterium halobium. $J$ Bacteriol, 171, 6323-9.

TANAKA, M., OGAWA, N., IHARA, K., SUGIYAMA, Y. \& MUKOHATA, Y. 2002. Cytochrome aa(3) in Haloferax volcanii. J Bacteriol, 184, 840-5.

TÄSTENSEN, J. B., JOHNSEN, U., REINHARDT, A., ORTJOHANN, M. \& SCHONHEIT, P. 2020. D-galactose catabolism in archaea: operation of the DeLey-Doudoroff pathway in Haloferax volcanii. FEMS Microbiol Lett, 367, fnaa029.

TE BRÖMMELSTROET, B. W., HENSGENS, C. M., KELTJENS, J. T., VAN DER DRIFT, C. \& VOGELS, G. D. 1990. Purification and properties of 5,10methylenetetrahydromethanopterin reductase, a coenzyme F420-dependent enzyme, from Methanobacterium thermoautotrophicum strain delta $\mathrm{H}$. Journal of Biological Chemistry, 265, 1852-57.

TITTES, C., SCHWARZER, S., PFEIFFER, F., DYALL-SMITH, M., RODRIGUEZFRANCO, M., OKSANEN, H. M. \& QUAX, T. E. F. 2021. Cellular and genomic properties of Haloferax gibbonsii LR2-5, the host of euryarchaeal virus HFTV1. Front Microbiol, 12, 625599.

TRIPEPI, M., YOU, J., TEMEL, S., ONDER, O., BRISSON, D. \& POHLSCHRODER, M. 2012. N-Glycosylation of Haloferax volcanii flagellins requires known Agl proteins and Is essential for biosynthesis of stable flagella. Journal of bacteriology, 194, 4876-87.

TRZEBIATOWSKI, J. R., O'TOOLE, G. A. \& ESCALANTE-SEMERENA, J. C. 1994. The cobT gene of Salmonella typhimurium encodes the NaMN: 5,6dimethylbenzimidazole phosphoribosyltransferase responsible for the synthesis of N1-(5-phospho-alpha-D-ribosyl)-5,6-dimethylbenzimidazole, an intermediate in the synthesis of the nucleotide loop of cobalamin. J Bacteriol, 176, 3568-75.

TURKOWYD, B., SCHREIBER, S., WORTZ, J., SEGAL, E. S., MEVARECH, M., DUGGIN, I. G., MARCHFELDER, A. \& ENDESFELDER, U. 2020.

Establishing live-cell single-molecule localization microscopy imaging and single-particle tracking in the archaeon Haloferax volcanii. Front Microbiol, 11, 583010.

UNIPROT, C. 2021. UniProt: the universal protein knowledgebase in 2021. Nucleic Acids Res, 49, D480-D89. 
1875

1876

1877

1878

1879

1880

1881

1882

1883

1884

1885

1886

1887

1888

1889

1890

1891

1892

1893

1894

1895

1896

1897

1898

1899

1900

1901

1902

1903

1904

1905

1906

1907

1908

1909

1910

UTHMAN, S., BAR, C., SCHEIDT, V., LIU, S., TEN HAVE, S., GIORGINI, F., STARK, M. J. \& SCHAFFRATH, R. 2013. The amidation step of diphthamide biosynthesis in yeast requires DPH6, a gene identified through mining the DPH1-DPH5 interaction network. PLoS Genet, 9, e1003334.

VAN OOYEN, J. \& SOPPA, J. 2007. Three 2-oxoacid dehydrogenase operons in Haloferax volcanii: expression, deletion mutants and evolution. Microbiology, 153, 3303-13.

VANNICE, J. C., SKAFF, D. A., KEIGHTLEY, A., ADDO, J. K., WYCKOFF, G. J. \& MIZIORKO, H. M. 2014. Identification in Haloferax volcanii of phosphomevalonate decarboxylase and isopentenyl phosphate kinase as catalysts of the terminal enzyme reactions in an archaeal alternate mevalonate pathway. J Bacteriol, 196, 1055-63.

VAUPEL, M. \& THAUER, R. K. 1995. Coenzyme F420-dependent N5,N10methylenetetrahydromethanopterin reductase (Mer) from Methanobacterium thermoautotrophicum strain Marburg. Cloning, sequencing, transcriptional analysis, and functional expression in Escherichia coli of the mer gene. Eur $J$ Biochem, 231, 773-8.

VAUPEL, M., VORHOLT, J. A. \& THAUER, R. K. 1998. Overproduction and one-step purification of the N5,N10-methenyltetrahydromethanopterin cyclohydrolase (Mch) from the hyperthermophilic Methanopyrus kandleri. Extremophiles, 2, 15-22.

VENCES-GUZMAN, M. A., GEIGER, O. \& SOHLENKAMP, C. 2008. Sinorhizobium meliloti mutants deficient in phosphatidylserine decarboxylase accumulate phosphatidylserine and are strongly affected during symbiosis with alfalfa. $J$ Bacteriol, 190, 6846-56.

WALSH, J. C., ANGSTMANN, C. N., BISSON-FILHO, A. W., GARNER, E. C., DUGGIN, I. G. \& CURMI, P. M. G. 2019. Division plane placement in pleomorphic archaea is dynamically coupled to cell shape. Mol Microbiol.

WANNER, C. \& SOPPA, J. 2002. Functional role for a 2-oxo acid dehydrogenase in the halophilic archaeon Haloferax volcanii. J Bacteriol, 184, 3114-21.

WERNER, A. K., MEDINA-ESCOBAR, N., ZULAWSKI, M., SPARKES, I. A., CAO, F. Q. \& WITTE, C. P. 2013. The ureide-degrading reactions of purine ring catabolism employ three amidohydrolases and one aminohydrolase in Arabidopsis, soybean, and rice. Plant Physiol, 163, 672-81.

WERNER, A. K., ROMEIS, T. \& WITTE, C. P. 2010. Ureide catabolism in Arabidopsis thaliana and Escherichia coli. Nat Chem Biol, 6, 19-21. 
1911 WEStenBerG, D. J., BRAUNE, A., RUPPERT, C., MULLER, V., HERZBERG, C.,

1912

1913

1914

1915

1916

1917

1918

1919

1920

1922

1923

1924

1925

1926

1927

1928

1929

1930

1931

1932

1933

1934

1935

1936

1937

1938

1939

1940

1941

1942

1943

1944

1945

1946 GOTTSCHALK, G. \& BLAUT, M. 1999. The F420H2-dehydrogenase from Methanolobus tindarius: cloning of the ffd operon and expression of the genes in Escherichia coli. FEMS Microbiol Lett, 170, 389-98.

WHITE, P. J. \& KELLY, B. 1965. Purification and properties of diaminopimelate decarboxylase from Escherichia coli. Biochem J, 96, 75-84.

WHITE, R. H. 1988. Analysis and characterization of the folates in the nonmethanogenic archaebacteria. J Bacteriol, 170, 4608-12.

WHITE, R. H. 2004. L-Aspartate semialdehyde and a 6-deoxy-5-ketohexose 1phosphate are the precursors to the aromatic amino acids in Methanocaldococcus jannaschii. Biochemistry, 43, 7618-27.

WILLIAMS, T. J., ALLEN, M. A., LIAO, Y., RAFTERY, M. J. \& CAVICCHIOLI, R. 2019. Sucrose metabolism in haloarchaea: reassessment using genomics, proteomics, and metagenomics. Appl Environ Microbiol, 85, e02935-18.

WISEMAN, J. S. \& NICHOLS, J. S. 1984. Purification and properties of diaminopimelic acid epimerase from Escherichia coli. J Biol Chem, 259, 890714.

WOODSON, J. D. \& ESCALANTE-SEMERENA, J. C. 2004. CbiZ, an amidohydrolase enzyme required for salvaging the coenzyme B12 precursor cobinamide in archaea. Proc Natl Acad Sci U S A, 101, 3591-6.

WOODSON, J. D., PECK, R. F., KREBS, M. P. \& ESCALANTE-SEMERENA, J. C. 2003a. The cobYgene of the archaeon Halobacterium sp. strain NRC-1 is required for de novo cobamide synthesis. J Bacteriol, 185, 311-6.

WOODSON, J. D., ZAYAS, C. L. \& ESCALANTE-SEMERENA, J. C. 2003b. A new pathway for salvaging the coenzyme B12 precursor cobinamide in archaea requires cobinamide-phosphate synthase (CbiB) enzyme activity. J Bacteriol, $185,7193-201$.

WYSS, L., WASER, M., GEBETSBERGER, J., ZYWICKI, M. \& POLACEK, N. 2018. mRNA-specific translation regulation by a ribosome-associated ncRNA in Haloferax volcanii. Sci Rep, 8, 12502.

XI, H., SCHNEIDER, B. L. \& REITZER, L. 2000. Purine catabolism in Escherichia coli and function of xanthine dehydrogenase in purine salvage. J Bacteriol, 182, 5332-41.

XU, Z., JIANG, W. H., JIAO, R. S. \& YANG, Y. L. 2002. [Cloning, sequencing and high expression in Escherichia coli of D-hydantoinase gene from Burkholderia picketti]. Sheng Wu Gong Cheng Xue Bao, 18, 149-54. 
1947

1948

1949

1950

1951

1952

1953

1954

1955

1956

1957

1958

1959

1960

1961

1962

1963

1964

1965

1966

1967

1968

1969

1970

1971

1972

1973

1974

1975

1976

1977

1978

1979

1980

1981

YANG, Y., YATSUNAMI, R., ANDO, A., MIYOKO, N., FUKUI, T., TAKAICHI, S. \& NAKAMURA, S. 2015. Complete biosynthetic pathway of the C50 carotenoid bacterioruberin from lycopene in the extremely halophilic archaeon Haloarcula japonica. J Bacteriol, 197, 1614-23.

YIN, J., XU, L. X., CHERNEY, M. M., RAUX-DEERY, E., BINDLEY, A. A., SAVCHENKO, A., WALKER, J. R., CUFF, M. E., WARREN, M. J. \& JAMES, M. N. 2006. Crystal structure of the vitamin B12 biosynthetic cobaltochelatase, CbiXS, from Archaeoglobus fulgidus. J Struct Funct Genomics, 7, 37-50.

YIN, W., CAI, X., MA, H., ZHU, L., ZHANG, Y., CHOU, S. H., GALPERIN, M. Y. \& HE, J. 2020. A decade of research on the second messenger c-di-AMP. FEMS Microbiol Rev, 44, 701-24.

YOSHIDA, A., TOMITA, T., ATOMI, H., KUZUYAMA, T. \& NISHIYAMA, M. 2016. Lysine biosynthesis of Thermococcus kodakarensis with the capacity to function as an ornithine biosynthetic system. J Biol Chem, 291, 21630-43.

YOSHIDA, A., TOMITA, T., FUJIMURA, T., NISHIYAMA, C., KUZUYAMA, T. \& NISHIYAMA, M. 2015. Structural insight into amino group-carrier proteinmediated lysine biosynthesis: crystal structure of the LysZ.LysW complex from Thermus thermophilus. J Biol Chem, 290, 435-47.

YU, Y., LIANG, Y. H., BROSTROMER, E., QUAN, J. M., PANJIKAR, S., DONG, Y. H. \& SU, X. D. 2006. A catalytic mechanism revealed by the crystal structures of the imidazolonepropionase from Bacillus subtilis. J Biol Chem, 281, 3692936.

ZAFRILLA, B., MARTINEZ-ESPINOSA, R. M., BONETE, M. J., BUTT, J. N., RICHARDSON, D. J. \& GATES, A. J. 2011. A haloarchaeal ferredoxin electron donor that plays an essential role in nitrate assimilation. Biochem Soc Trans, 39, 1844-8.

ZAHN, S., KUBATOVA, N., PYPER, D. J., CASSIDY, L., SAXENA, K., THOLEY, A., SCHWALBE, H. \& SOPPA, J. 2021. Biological functions, genetic and biochemical characterization, and NMR structure determination of the small zinc finger protein HVO_2753 from Haloferax volcanii. FEBS J, 288, 2042-62.

ZAYAS, C. L. \& ESCALANTE-SEMERENA, J. C. 2007. Reassessment of the late steps of coenzyme B12 synthesis in Salmonella enterica: evidence that dephosphorylation of adenosylcobalamin-5'-phosphate by the CobC phosphatase is the last step of the pathway. J Bacteriol, 189, 2210-8. 
1982

1983

1984

1985

1986

1987

1988

1989

1990

1991

1992

1993

1994

1995

1996

1997

1998

1999

2000

2001

2002

2003

ZERULLA, K., CHIMILESKI, S., NATHER, D., GOPHNA, U., PAPKE, R. T. \& SOPPA, J. 2014. DNA as a phosphate storage polymer and the alternative advantages of polyploidy for growth or survival. PLoS One, 9, e94819.

ZHANG, F., SCHEERER, P., OBERPICHLER, I., LAMPARTER, T. \& KRAUSS, N. 2013. Crystal structure of a prokaryotic (6-4) photolyase with an Fe-S cluster and a 6,7-dimethyl-8-ribityllumazine antenna chromophore. Proc Natl Acad Sci U S A, 110, 7217-22.

ZHANG, P., BATTCHIKOVA, N., PAAKKARINEN, V., KATOH, H., IWAI, M., IKEUCHI, M., PAKRASI, H. B., OGAWA, T. \& ARO, E. M. 2005. Isolation, subunit composition and interaction of the NDH-1 complexes from Thermosynechococcus elongatus BP-1. Biochem J, 390, 513-20.

ZHU, X., DZIKOVSKI, B., SU, X., TORELLI, A. T., ZHANG, Y., EALICK, S. E., FREED, J. H. \& LIN, H. 2011. Mechanistic understanding of Pyrococcus horikoshii Dph2, a [4Fe-4S] enzyme required for diphthamide biosynthesis. Mol Biosyst, 7, 74-81.

ZHU, X., KIM, J., SU, X. \& LIN, H. 2010. Reconstitution of diphthine synthase activity in vitro. Biochemistry, 49, 9649-57.

ZIMMERMANN, B. H., NITSCHE, C. I., FEE, J. A., RUSNAK, F. \& MUNCK, E. 1988. Properties of a copper-containing cytochrome ba3: a second terminal oxidase from the extreme thermophile Thermus thermophilus. Proc Natl Acad Sci U S A, 85, 5779-83. 